\title{
Archaeological and Historical Investigations at the Alamo North Wall San Antonio, Bexar County, Texas
}

James E. Ivey

Center for Archaeological Research

Anne A. Fox

Center for Archaeological Research

Follow this and additional works at: https://scholarworks.sfasu.edu/ita

Part of the American Material Culture Commons, Archaeological Anthropology Commons, Environmental Studies Commons, Other American Studies Commons, Other Arts and Humanities Commons, Other History of Art, Architecture, and Archaeology Commons, and the United States History Commons

Tell us how this article helped you.

This Article is brought to you for free and open access by the Center for Regional Heritage Research at SFA ScholarWorks. It has been accepted for inclusion in Index of Texas Archaeology: Open Access Gray Literature from the Lone Star State by an authorized editor of SFA ScholarWorks. For more information, please contact cdsscholarworks@sfasu.edu. 


\section{Archaeological and Historical Investigations at the Alamo North Wall San}

Antonio, Bexar County, Texas

\section{Creative Commons License}

\section{(c) (1) (8)}

This work is licensed under a Creative Commons Attribution-NonCommercial 4.0 International License 


\title{
Archaeological and Historical Investigations at the Alamo North Wall San Antonio, Bexar County, Texas
}

\author{
James E. Ivey and Anne A. Fox \\ with contributions by \\ David M. Glassman, Robert F. Scott IV, \\ and D. Gentry Steele \\ Robert J. Hard, Thomas R. Hester, and Jack D. Eaton \\ Principal Investigators
}

Texas Antiquities Committee Permit No. 196

${ }^{\circledR}$ copyright

Center for Archaeological Research

The University of Texas at San Antonio

Archaeological Survey Report, No. 224 
The following information is provided in accordance with the General Rules of Practice and Procedure, Chapter 41.11 (Investigative Reports), Texas Antiquities Committee:

1. Type of investigation: Testing

2. Project name: Archaeological and Historical Investigations at the Alamo North Wall (41BX6)

3. County: Bexar

4. Principal investigators: Robert J. Hard, Thomas R. Hester, and Jack D. Eaton

5. Name and location of sponsoring agency: Daughters of the Republic of Texas, The Alamo, San Antonio, Texas

6. Texas Antiquities Committee Permit No.: 196

7. Published by the Center for Archaeological Research of The University of Texas at San Antonio, 6900 N. Loop 1604 W., San Antonio, Texas 78249-0658, 1997

A list of publications offered by the Center for Archaeological Research is available. Call (210) 4584378; write to the Center for Archaeological Research, The University of Texas at San Antonio, 6900 N. Loop 1604 W., San Antonio, Texas 78249-0658; e-mail to car@lonestar.utsa.edu; or visit CAR's Web site at http://www.csbs.utsa.edu/research/car/index.htm. 


\section{Abstract}

In March 1979, the Center for Archaeological Research of The University of Texas at San Antonio conducted test excavations in the vicinity of the north wall of the Alamo within the second patio. A great deal of information was recovered about all phases of the development of the site, from the early eighteenth century through the restoration period in the early twentieth century.

Information was recovered on the location and dimensions of defensive trenches and structures constructed in the north courtyard in preparation for the battles of late 1835 and March 1836. A human cranium recovered from the fill of a defensive trench has been identified as possibly a male about 17 to 23 years of age. The ethnic affiliation of the individual could not be positively determined, nor could the cause of death. 


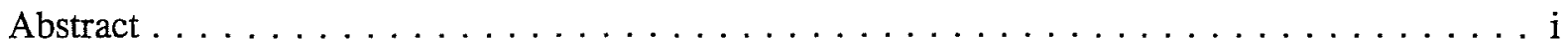

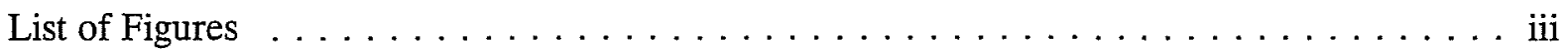

List of Tables $\ldots \ldots \ldots \ldots \ldots \ldots \ldots \ldots \ldots \ldots \ldots \ldots \ldots \ldots \ldots \ldots \ldots \ldots$

Acknowledgments $\ldots \ldots \ldots \ldots \ldots \ldots \ldots \ldots \ldots \ldots \ldots \ldots \ldots \ldots$ iv

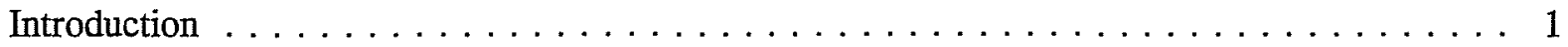

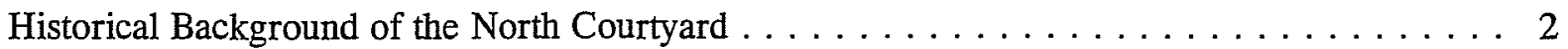

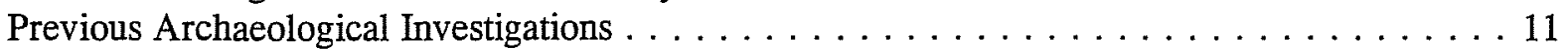

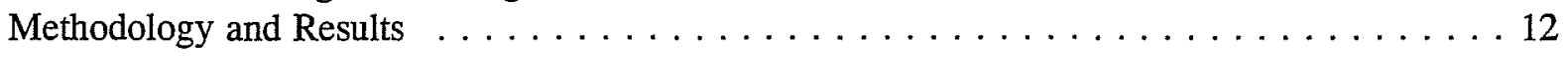

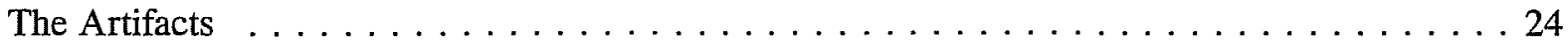

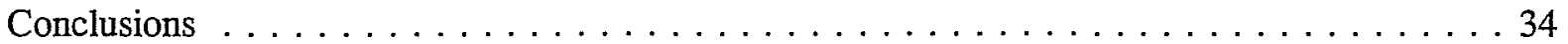

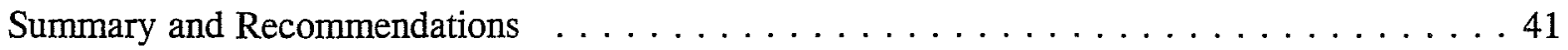

References Cited . . . . . . . . . . . . . . . . . . . . . . . . 42

Appendix A: Faunal Analysis for the Alamo North Wall Excavations

Robert F. Scott IV . . . . . . . . . . . . . . . . . . . . 46

Appendix B: Osteobiography of the Alamo North Wall Cranium

David M. Glassman and D. Gentry Steele . . . . . . . . . . . . . . . . . 61 
1. Locations of north wall excavations at north courtyard on Alamo grounds. . . . . . . . 1

2. Map of the Alamo in 1836, attributed to Green Jameson . . . . . . . . . . . . . . 6

3. Plano del Fuerte del Alamo by Sánchez-Navarro, $1836 \ldots \ldots \ldots \ldots \ldots$

4. Map drawn for Santa Anna in March 1836 by Colonel Ygnacio de Labastida . . . . . . . . 8

5. Excavation units at the north wall in the north courtyard. . . . . . . . . . . 13

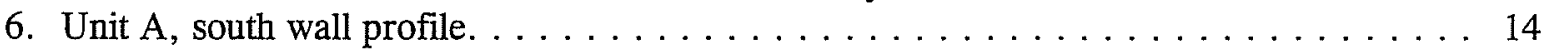

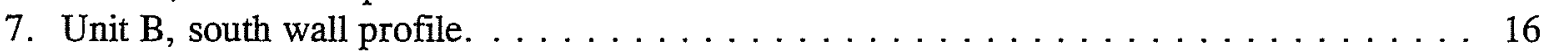

8. Unit $C$, south wall profile and plan view $\ldots \ldots \ldots \ldots \ldots \ldots \ldots \ldots$

9. Unit $\mathrm{D}$, east, south, west, and north wall profiles. $\ldots \ldots \ldots \ldots \ldots \ldots \ldots$

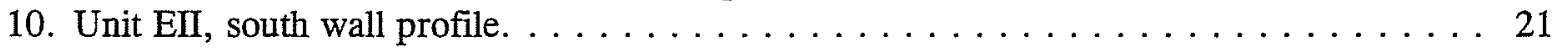

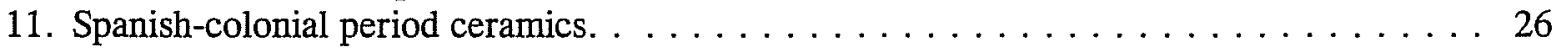

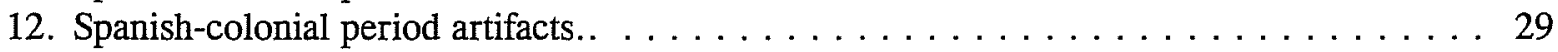

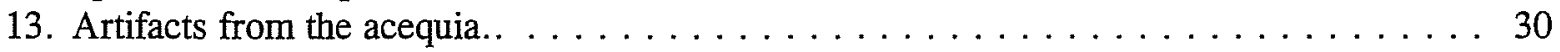

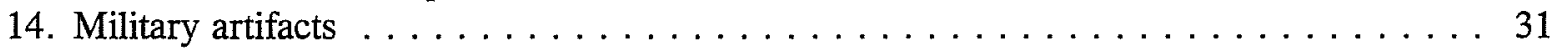

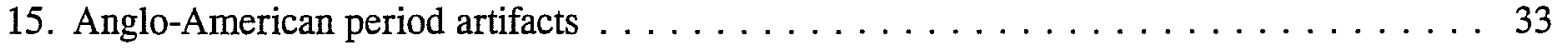

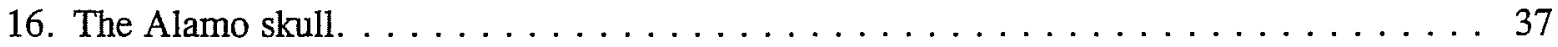

\section{Tables}

A-1. Phase I, Bone Recovery . . . . . . . . . . . . . . . . . 47

A-2. Phase I, Faunal Identification and Occurrence $\ldots \ldots \ldots \ldots \ldots \ldots \ldots \ldots \ldots . \ldots . \ldots 49$

A-3. Phase I, Butcher-marked Skeletal Elements by Unit . . . . . . . . . . . 50

A-4. Phase II, Bone Recovery . . . . . . . . . . . . . . . . . 53

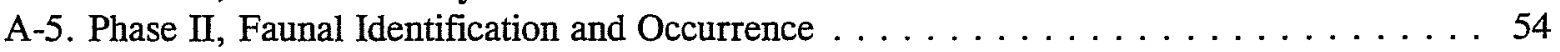

A-6. Phase II: Butcher-marked Skeletal Elements by Unit $\ldots \ldots \ldots \ldots \ldots \ldots \ldots \ldots 5$

B-1. Metric Observations of the 41BX6 Cranium . . . . . . . . . . . . 62 


\section{Acknowledgments}

Thanks are due to the Daughters of the Republic of Texas (DRT) for initiating and expediting these excavations. We are also grateful for the generous cooperation of Charles Long, Kevin R. Young, and John Leal as well as the staff of the DRT Library on the Alamo grounds for help in background research. Dr. David Glassman of Southwest Texas State University and Dr. D. Gentry Steele of Texas A\&M University kindly donated their considerable skills and knowledge in assessment of the human skull recovered. Thanks also go to Sam Nesmith for analyzing the gun parts and related objects.

Members of the excavation crew included Augustine Frkuska, Lois Flynn, Kathy Gonzalez, James Ivey, Herbert Uecker, and Shirley Van der Veer. Robert F. Scott IV did the faunal analysis, and Marcie Renner edited the report for publication. 


\section{Introduction}

In March 1979, the Center for Archaeological Research (CAR) of The University of Texas at San Antonio entered into a contract with the Daughters of the Republic of Texas (DRT) to conduct archaeological investigations in the vicinity of the north wall of the north courtyard at the Alamo (41BX6), a National Register of Historic Places site (Figure 1). The purpose of the investigations was to obtain information on earlier walls and wall footings in the immediate area of the present wall, in preparation for the proposed reconstruction of the north wall. It was also imperative to discover whether the present footings would be substantial enough to support the new wall or whether additional footings would need to be

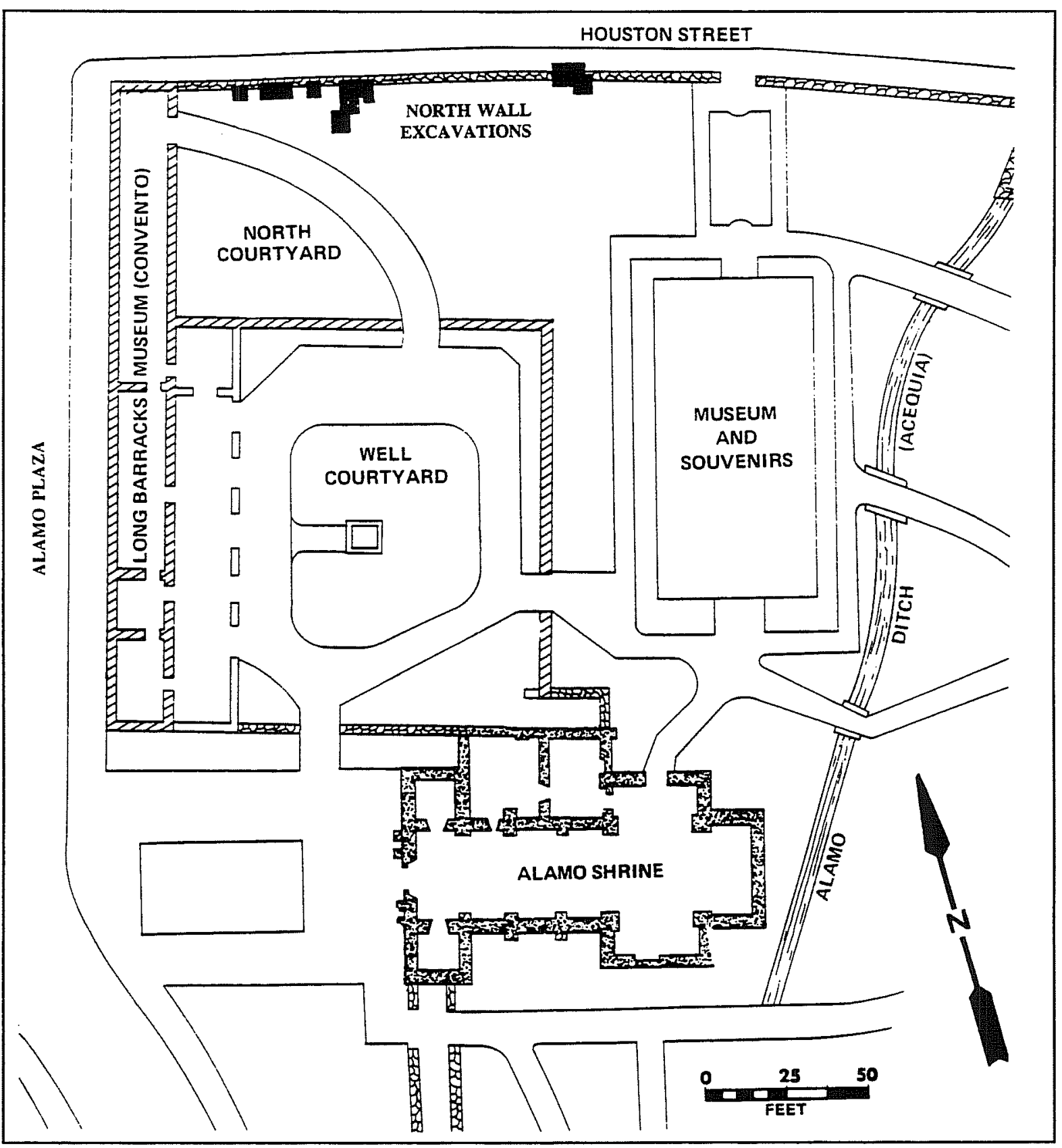

Figure 1. Locations of north wall excavations at north courtyard on Alamo grounds. 
constructed. These investigations were conducted in two stages (Phase I and Phase II) because the DRT modified their original construction plans after the initial north wall excavations (Phase I).

Upon completion of the investigations along the north wall, the DRT began the construction of a stockade wall along Houston Street. The first step in this construction was the excavation of a trench along the south side of the remains of the most recent wall (built in 1926) which had been removed down to ground level prior to our Phase I excavations.

This trench was dug along the entire length of the 1926 wall foundation, except where trees, utility meters, and underground pipes interfered. At this point, for several reasons, the idea of a stockade wall was reconsidered, and the decision was made to build a new stone wall to match the rest of the Alamo Park wall. The foundation of the 1926 wall had to be removed for this construction, which would cause further disturbance of the ground. This required CAR to carry out additional investigations (Phase II) in selected areas.

The Phase I work was done by a field crew of three technical staff assistants and numerous volunteer workers from the Southern Texas Archaeological Association (STAA), under the supervision of Anne Fox, CAR research associate. The investigations were carried out under the Texas Antiquities Committee Permit No. 196. All work was done in accordance with General Rules of Practice and Procedure Chapter 41.11 (Investigative Reports) of the Council of Texas Archeologists.

The additional work, Phase $\Pi$, was done in February 1980 . The crew of six was directed by James Ivey, under the supervision of Anne Fox.

\section{Historical Background of The North Courtyard}

Mission San Antonio de Valero was established on the west bank of the San Antonio River, about a mile south of San Pedro Springs, in the summer of 1718 . In 1719 the mission was moved to the east bank of the river (Habig $1977: 25$, 32), about $3,500 \mathrm{ft}$ south of the present old church structure which is now the Alamo Shrine.

By 1724 a small chapel with a stone tower and several small jacales had been built (Habig 1977:35). In that year the mission was severely damaged by high winds, so the location was again changed, to the present site (Habig 1977:35). Between 1724 and 1727, the first ground-floor rooms of the convento (the southern half of the present Long Barracks) were built. In 1727 Fray Miguel Sevillano de Paredes reported three rooms of the convento were complete, and a gallery and fourth room were under construction. A group of Indian quarters was complete, as were several strong jacales for the missionaries and one used as the church. Work had not yet begun on the new church, although the stone and other necessary materials had been collected. De Paredes indicated that construction of the new church could not begin for lack of a qualified stonemason, but he hoped work would start soon (Chabot 1937:140).

Nothing is known of the development of the mission buildings between 1727 and 1744, when a note in the baptismal records indicated the first stone of the new church was finally laid (Habig 1977:50). The delay from 1727 until 1744 was probably caused by the continuing absence of a competent mason, as well as the political and military difficulties of those years.

In 1745 Fray Francisco Xavier Ortiz inspected the Texas missions. He found the new church was under construction and the old one, the jacal mentioned in the 1727 report, had collapsed (Ortiz 1745). Ortiz said that while the 
new church was being built, a large adobe hall was being used as a church, with an adjoining room used as a sacristy. The convento building had been increased to two stories, with offices, a kitchen, and a dining room on the first floor, and three private rooms on the second (Habig 1977:56). These rooms probably faced into a small patio, today's well courtyard. Adjoining the convento courtyard was a second patio or courtyard containing a clothmaking workshop with an open gallery, a carpenter's shop, a blacksmith shop, several offices, and a granary. The general plan of the mission buildings in 1745 was maintained and elaborated upon throughout the rest of the history of the Alamo; portions of these buildings probably survive in today's Long Barracks.

By 1793 the convento had been expanded until its ground floor extended around the four sides of the present well courtyard (Old Spanish Missions Historic Research Library [OSMHRL], Mission San José, San Antonio, Texas, missions microfilm roll 4). The second floor of the west side continued around the southwest corner and along the south side of the patio. The one-story section along the north side was only partially roofed, the east side was nothing but bare walls.

The church itself remained unfinished and in virtually the same condition from at least 1772 . The decorative facade was finished only to a height of about $25 \mathrm{ft}$; from the description it looked virtually the same in 1793 as it does today. No towers had been built, although the bases for the towers were present (Eaton 1980:Figure 6). The apse, at the east end of the church, was the only portion with any vaulting. The remainder of the church had the arches to support the dome and the vaulting of the nave and transepts, but not all these were finished. Since the mission was secularized in 1793 , no further work was done. Subsequent stories about the church being full of rubble from its fallen vaults and towers are not altogether true; undoubtedly, some rubble would have been present had one or more of the arches fallen, but this would have consisted only of scattered cut stone blocks.

In the north courtyard the building which is now the north half of the Long Barracks was built as a granary before 1745 but had served in the 1740 s as the church. In 1793 this building contained the equipment usually found in a granary, such as a large sieve and several measures of various sizes; but the roof was being replaced or was incomplete, so a nearby jacal was being used as a temporary granary (OSMHRL, microfilm roll 4). Next to the granary, within the present courtyard, were several other rooms of the workshop complex, which had been in use throughout the years 1745-1793 (OSMHRL, microfilm roll 4). The clothmaking workshop was apparently directly east of and adjoining the granary, but the locations of the other workshop rooms within the courtyard are uncertain. They were likely placed along the walls of the courtyard rather than in its central areas, but no descriptions of any such walls along the north or east sides of the courtyard have yet been found.

In 1793 San Antonio de Valero was secularized (Habig 1977:66), and the property outside the walls was divided among the mission Indians and a group of refugees from the Presidio los Adaes and its associated missions in east Texas, which had been closed in 1772 . The property within the walls of the mission remained nominally in the hands of the Catholic church, although the Spanish government exercised considerable control over it. In about 1803, the Segunda Compañía Volante de San Carlos de Parras del Alamo, a company of Spanish Cavalry, was assigned to San Antonio and posted to the mission grounds in the barracks. They occupied the mission intermittently from 1803 until about 1825 (Habig 1977:71).

Little is presently known about changes to the Alamo buildings introduced by the Compañia Volante. The available evidence indicates they were probably housed in the old Indian quarters. That the structure along the south side 
of the Alamo compound, now called the "low barracks," was built at this time is likely. The presence of the Compañia Volante prompted the Spanish government to establish a hospital on the Alamo grounds in 1805 in one "partly ruined chamber in the secularized Mission of Valero" (Nixon 1936:17). This was one of the rooms of the convento. In 1806 the facilities of the small hospital were improved and, in 1807, two rooms were constructed or rebuilt to serve as a pharmacy for the hospital (Nixon 1936:17).

By 1809 , if the hospital was to survive, the Alamo buildings needed extensive renovation. Three local masons examined the convento structure and made estimates of the necessary repairs, materials, and costs. The majority of the flat cement roofs had to be replaced; most of the walls had to be patched, plastered, and white-washed; many of the floors needed to be rebuilt; and two areas where walls were about to fall had to be reconstructed. Most of the roofing beams and roof drains were rotten and needed to be replaced (Bexar County Archives [BA], Office of the County Clerk, Bexar County Courthouse, San Antonio, Texas, May 2,1809 , microfilm roll 41:205). The work took almost a year to complete and cost about 6,000 pesos (Nixon 1936:27-28). This was apparently the last major repair and construction on the Alamo buildings until 1835. The hospital was closed around 1812 as the financial and political problems of Spain in Texas increased (Nixon 1936:28).

From 1812 until about 1820 , revolution and unrest kept the Compañia Volante away from the Alamo most of the time. During this period the abandoned convento buildings deteriorated, and roofs and walls began to decay and collapse again. By about 1825 , soldiers and local citizens began to petition the Mexican government for the right to purchase the Indian quarters and other land belonging to the Alamo outside the convento and church; during the late 1820 s, the Mexican government consented (BA March 13, 1829 , microfilm roll $120: 728$ ).
With the onset of hostilities between AngloAmerican Texans and the Mexican government in 1835, General Perfecto de Cós, commander of the Mexican forces in Texas, began to fortify San Antonio and the Alamo. Just how much of the fortifications were built by Cós and how much by the Texans later, in 1836, is questionable. Lord $(1961: 60,77)$ presents the view that the majority of the defenses were built by the Texans, but this was probably not the case. According to Samuel Maverick's journal (Green 1952:28), written in San Antonio during most of the siege of Bexar (October-December 1835), Cós arrived in San Antonio on October 8. Texan troops marching on San Antonio from Gonzales began to be reported on October 12; on that date Cós ordered the fortification of the Alamo to begin: "Timbers \& c. taken to $\mathrm{El}$ Alamo to fortify the Quartel" (Green 1952:29). By October 18, 300 cavalry and 200 infantry were stationed in the Alamo and available to be used as work force. The Texan troops crossed Salado Creek and reached the immediate area of San Antonio on October 21. A series of small actions began between the Mexican and Texan forces, but never escalated into a full-scale battle.

On October 26, 1835, Maverick noted, “an 18 pounder just mounted. Was carried by to the Alamo [sic]" (Green 1952:32). He added this made seven cannons mounted in the Alamo, "of which one, the 18 pounder, is on the top of the old church of San Antonio" (Green 1952:32). By November 3, Maverick stated, "the quartel in the Alamo is very strongly fortified" (Green 1952:35). After that date he made no further references to fortification work at the Alamo. Throughout November 1835, Maverick observed repeated instances of exchanges of cannon, musket, and rifle fire between the Mexican troops within the Alamo and the Texan forces besieging San Antonio. Throughout the fortification and siege, Maverick indicated that Colonel Domingo de Ugartechea was in command of the fortification and defense of the Alamo, while Cós commanded the defenses built around Military Plaza in San Antonio. 
On December 1, Maverick left San Antonio and joined the Texan forces. A major assault was made on San Antonio beginning December 5; fighting continued until December 10 when Cós surrendered (Green 1952:43-44). Maverick's information specifically relates that forces under Cós constructed fortifications at the Alamo from October 12 until about November 3 and that, by October 26, the engineers had built a large ramp and platform inside the nave of the church. Maverick gives no detailed description of the defenses built by Cós, but several Mexican officers present at the battle of the Alamo did so; these leave no doubt that virtually all ditches and gun positions in use during the battle were built by the engineers of Col. Ugartechea by order of General Cós. Green Jameson, who acted as military engineer for the Texan troops stationed at the Alamo after the capture of San Antonio, is described by Lord (1961:59) as being a lawyer from San Felipe with no military background or practical experience. He made extensive plans for new fortifications but apparently never had the time nor manpower to carry out any more than the movement of several cannon to defend against an attack from the direction of San Antonio rather than from the east and southeast, in the direction of Goliad and Gonzales. This included the movement of the 18-pounder from the top of the church in the southeastern corner of the Alamo to another platform in the southwest corner.

The actual plan of defense, as of February 1836 , is another topic of historical debate. Until recently, the map generally cited by historians has been the plan drawn by Green Jameson in January 1836. The original of this map has disappeared, but the plan survives in several publications, apparently in very modified form (Figure 2). Two other maps, drawn in 1836 but relatively ignored, are those of Colonel Sánchez-Navarro (Figure 3), who returned with Santa Anna in February 1836 after retreating with Cós after the surrender of San Antonio in December 1835; and of Colonel Ygnacio de Labastida (Figure 4), the commander of engineers of the army of the north under Santa
Anna. These maps agree well with the descriptions left by eyewitnesses de la Peña (1975[1836]) and Filisola (1965[1836]). Sánchez-Navarro includes a detailed index and discussion with his map. The maps agree, in general, on the location of the various buildings within the Alamo and the placement of the guns. Sánchez-Navarro's map, apparently drawn from memory and notes in mid-1836 after his second retreat from Texas, is the least trustworthy in terms of agreement of the details of his plans and discussion with known facts and with the other maps and narratives.

The 1836 maps show that no traces of the convento building east of those facing onto the Main Plaza of the mission had survived the long neglect from about 1812 until the fortification in 1835. In fact, much of the ruins of these structures was probably used in construction of the gun platform in the Alamo church since, as stated earlier and contrary to tradition, the church was not full of the ruins of its vaults and towers, but only a little rubble from the ribs of the nave and the vault over the apse. In the north courtyard, these maps show a gun platform and ramp at the northeast corner of the walls and a trench along the interior of the walls. The map drawn by Sánchez-Navarro shows ditches along the north and east walls of the courtyard, while Labastida's map depicts a ditch along only the north wall. Both maps show the edge of the trench facing inward toward the courtyard as denticulate, the width of the ditch varying in rectangular zigzags. Labastida's map further indicates a circular ditch outside the northeast corner of this courtyard, protecting the gun platform.

When the Alamo fell on March 6,1836, the Mexican army reorganized and marched eastward, pursuing General Houston and the Texan forces. A garrison was left in San Antonio under the command of General Juan Andrade. Among other duties, Andrade was ordered to repair and improve the defenses of the Alamo. After the defeat of the Mexican army at San Jacinto on April 21, Andrade received orders to destroy the defenses of the 


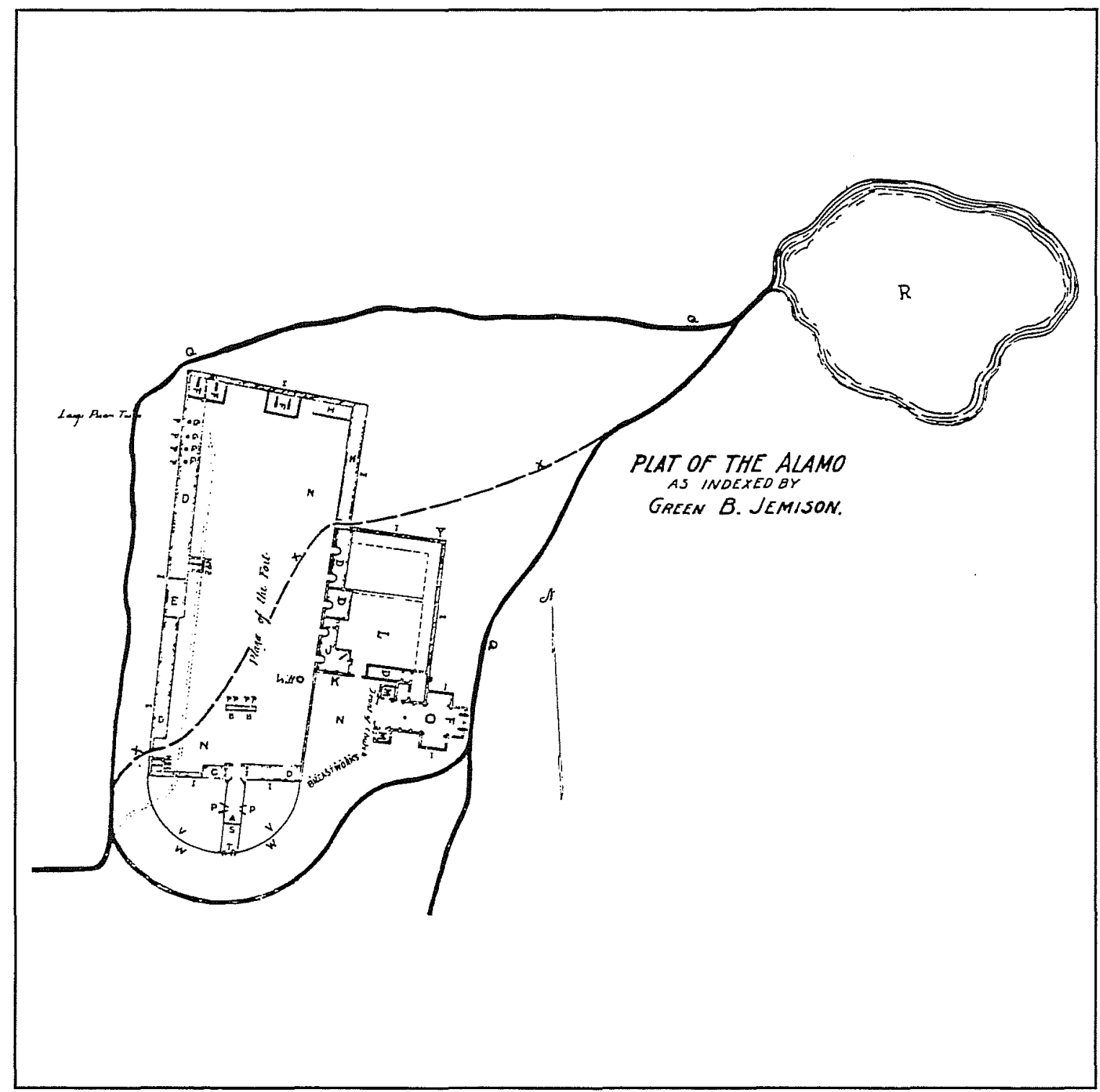

Figure 2. Map of the Alamo in 1836, attributed to Green Jameson (Schoelwer 1985).

Alamo and to retreat from Texas. Sometime between May 22 and 24, he carried out these orders. De la Peña (1975[1836]:188) says Andrade had worked his troops hard on repairs to the Alamo buildings, "he had labored to put the Alamo in the best possible condition for defense; this had already been improved when it became necessary to raze it; and few do not know the pain such an operation causes a soldier, a pain even greater to one who knows the duties of his profession well." Dr. J. H. Barnard described the Alamo as he saw it on
May 24 as the Mexican garrison was leaving town, "the Alamo was completely dismantled, all the single walls were leveled, the fossee [probably fosses] filled up, and the pickets torn up and burnt" (Huson 1949:44-45).

After the War of Independence, families who owned various portions of the old Alamo buildings slowly moved back into the area. These included the Losoyas, Treviños, Castañedas, and Romanos. In 1841 Samuel A. Maverick, an early Anglo settler in San Antonio 


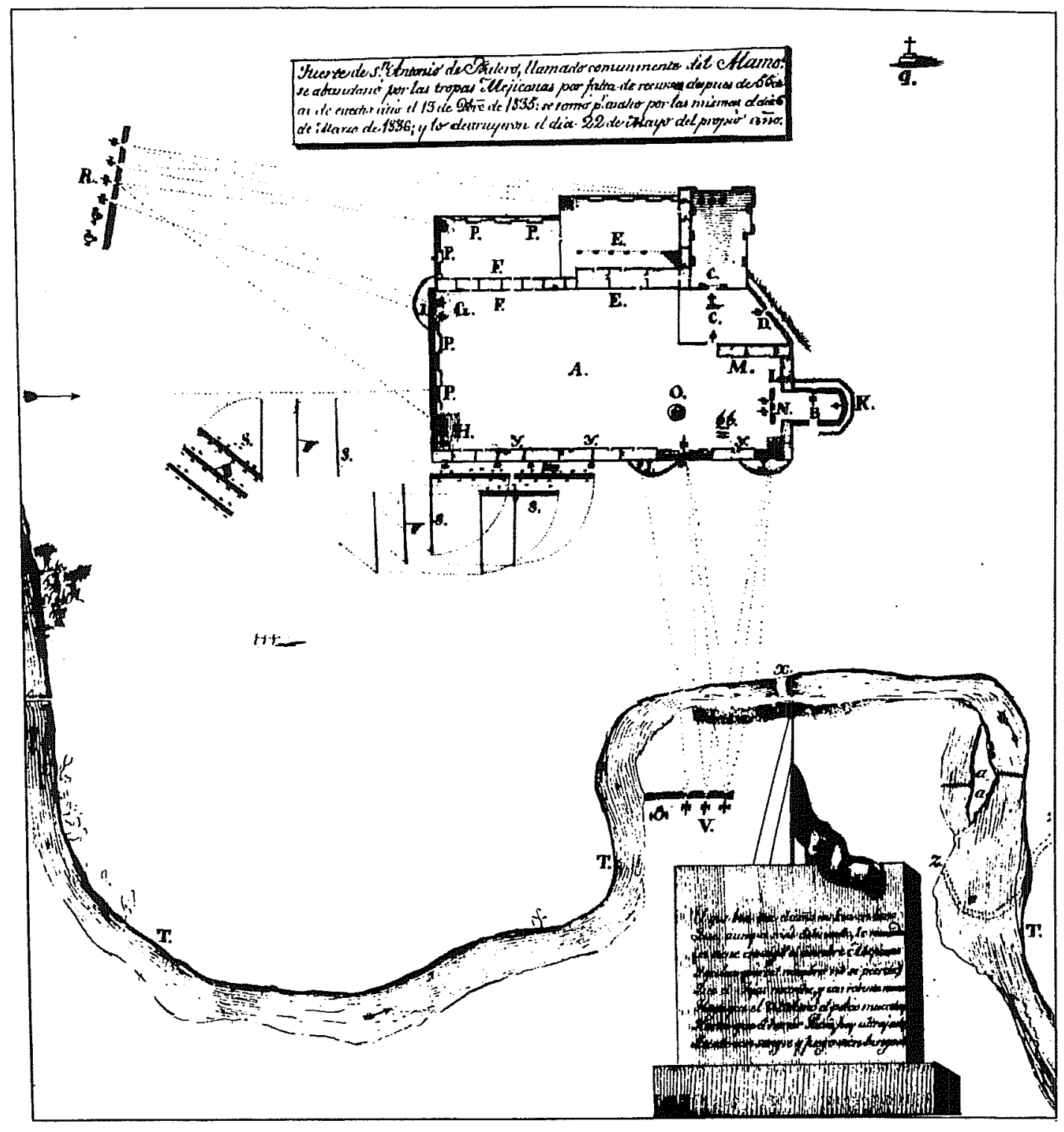

Figure 3. Plano del Fuerte del Alamo by José Juan Sánchez-Navarro, 1836. Copy in the Eugene C. Barker Texas History Collection, The University of Texas at Austin.

who was a prominent businessman and land speculator, began to purchase property along the north side of the Alamo. He bought the north half of the western wall from Maria Castañeda, the widow of Lieutenant Francisco Castañeda who had commanded the Compañia Volante during the war. The Castañedas had lived in one of the reconditioned Indian houses of the old mission since at least 1825 (Bexar County Deed Records [BCDR], Bexar County
Courthouse, San Antonio, Texas, Volume F1:206; A2:415). Lieutenant Castañeda commanded the small force sent to Gonzales to retrieve the cannon in the hands of the colonists, an incident which had triggered the active hostilities of the Texas Revolution (Webb 1952: $\mathrm{I}: 306)$. The Castañeda house became the residence of the Mavericks while Samuel built a new house on the northwest corner of Alamo Plaza (Green 1952:349). 


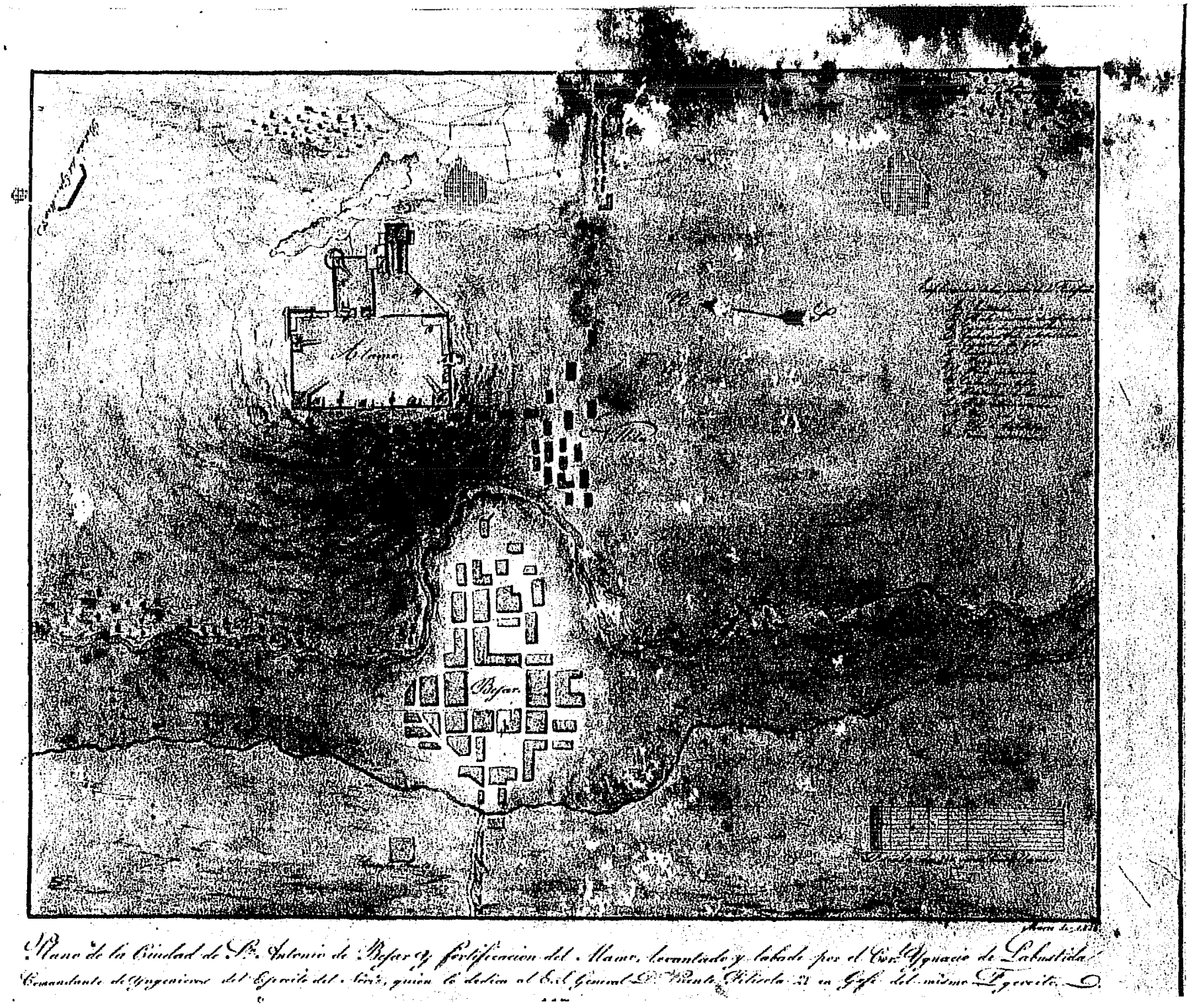

Figure 4. Map drawn for Santa Anna in March 1836 by Colonel Ygnacio de Labastida, Commander of Engineers. Copy in the Eugene C. Barker Texas History Collection, The University of Texas at Austin. 
Maverick also purchased all the property along the north wall of the Alamo and the east side to the convento from Mariano Romano (BCDR $A 2: 470$ ). In the deed from Romano is a clear statement of the position and construction of the north wall of the north courtyard in 1841: the property line ran down the east side of Alamo Plaza to the northwestern corner of the old granary, now the Long Barracks, and then "eastward ... on and along with an old stone fence to the corner of an enclosure where said fence stops and turns southward-thence the line turns southward, with said old stone fence and as far as said fence extended, and down to where this lot terminated, close to the church." This line was surveyed by Francois Giraud in 1849 , and recorded in the City Survey Book, pages 114-11; a copy of this plan is printed in Fox et al. (1976:19). The property line as it runs east from the north end of the Long Barracks is the same line which forms the northern boundary of the Alamo property along Houston Street today.

The description "old stone fence" reveals that in 1841 , less than six years after the battle of the Alamo, the remains of the northern and eastern walls which formed part of the defenses of the north courtyard must have looked like the remains of any other fallen wall, visible only as low ridges of stone rubble and earth.

Fallen rubble was still visible in September 1846 when Edward Everett, a member of the expedition of General John E. Wool to Parras, drew his plan of the Alamo grounds (Colquitt 1913:114; Fox et al. 1976:16). Everett found sufficient traces of a wall along the north and east sides of the north courtyard to show them with parallel dotted lines in the same manner as he indicated the main walls of the Alamo quadrangle (Fox et al. 1976:Figure 4). C. W. Thomas, Quartermaster for the Wool expedition, decided to establish a U.S. Army Quartermaster Depot in the ruins of the Alamo after suitable repairs had been made. The U.S. Army had already placed a blacksmith shop here, and Thomas
... had several of the rooms cleaned out, and temporary roofs thrown over them and removed the saddlers and wheelwrights from the city into them. Leaving shortly after with General Wool's column, I left instructions with Captain William Wall, to have my plans carried into effect and to remove the whole depot, as soon as the repair could be made [Young ca. 1970s:18].

Captain J. H. Ralston assumed command of the U.S. Army Quartermaster Depot in January 1847, and began the job of converting the Alamo ruins into a storehouse.

On February 20, 1847, Ralston estimated the roofing and repair of the Long Barracks would cost $\$ 1,555.90$ (Young ca. 1970s:22). By March 19, he stated he had "made some repairs" to the old convento buildings, and was also speculating on the possibility of repairing the church for additional storage space (Young ca. 1970s:24). On September 20 he reported, "by the end of the present month another part of the Alamo will be repaired for a Quartermaster's office and for storage of the residue of the Quartermaster's Stores" (Young ca. 1970s:26). Apparently the repairing and roofing of the convento was completed by the end of 1847.

By mid-1848, according to an updated version of Edward Everett's map included in Ralston's final report of February 10, 1849 (Plan of the US Depot at the Alamo, San Antonio de Bexar, in final report of J. H. Ralston, copy on file at the DRT Library, the Alamo, San Antonio, Texas), the army had built a "horse shed" or stable along the east side of the old granary in the north courtyard. A picket fence had been built running east from the convento buildings to the acequia along the line where Everett showed a trace of a wall dividing the north and south courtyards. This was $20 \mathrm{ft}$ south of the line of the present wall between the courtyards. 
In mid-May a second army map (Plan of the Quarter Master's Depot, The Alamo, San Antonio, Texas, May 24, 1849, records of the office of the quartermaster general, record group 92, copy on file at the DRT Library, the Alamo, San Antonio, Texas) was made showing the stables against the east wall of the Long Barracks and a second stable along the line of the old east wall of the north courtyard, a wall line no longer marked on the map. These stables extended north and east across the property line onto Samuel Maverick's land, indicating the army was already leasing this property from Maverick, although no official arrangement is mentioned before October 1851.

Captain Ralston was relieved December 17, 1848 , by Captain M. S. Miller who assumed the duties of assistant quartermaster (Young ca. 1970s:39). In March 1848, the chief assistant quartermaster was Major E. B. Babbitt. Major Babbitt received permission from the army early in 1850 to proceed with plans to roof the church building. By mid-May he reported "I am now about to cover the Alamo Church" (Young ca. 1970s:61), and said he had delayed until the question of who actually owned the land-the Catholic church, the city of San Antonio, or the federal government-was reasonably settled. The new top of the facade of the church building was designed by architect John Fries (Steinfeldt 1978:28); the whole renovation was probably completed by 1851 .

By October 1851 , as stated above, the army had officially leased the property from the east edge of the old courtyard complex to the acequia from the Maverick family (Fox et al. 1976:18). At about the same time, old Rivas Street in downtown San Antonio was extended eastward to the San Antonio River, where a bridge was built connecting it with old Paseo Street on the west side of Alamo Plaza; Paseo Street was extended eastward across Alamo Plaza and the north end of the Long Barracks to the acequia. Both streets were then renamed Houston Street (Heusinger 1951:25). The result was that the army lost its corrals and stables north of
Houston Street, which undoubtedly prompted further additions to the structures within the courtyard complex, producing a series of stables and sheds laid out around an inner yard or patio approximately equivalent to the present north courtyard (A. Koch, 1873, Bird's Eye View of the City of San Antonio. Map, copy on file at the DRT Library, the Alamo, San Antonio, Texas).

Later, during the Civil War, the Alamo became a Confederate Army depot, then reverted to the U.S. Army at the end of the war. The army relinquished the property to the Catholic church in late 1877. On November 30, 1877, the Alamo buildings were purchased from the church by Honore Grenet who immediately began the work of converting the old convento buildings into a store and warehouse (BCDR Vol. $7: 373$ ).

Grenet removed the roof built by the army and tore down all the walls and floors east of the facade facing onto Alamo Plaza. On the south side he tore down the northern third of the sacristy of the Alamo church and several other walls of the church which extended across his property line. He added an eastward extension to the stone facade along Houston Street, which made the building about $55 \mathrm{ft}$ wide east to west (Sanborn Map and Publishing Company, Ltd. 1885, copy on file at the DRT Library, the Alamo, San Antonio, Texas). The facades to the west, north, and south had wooden galleries added, and the new line of the east wall was built of wood. Apparently the old army stables and sheds in the courtyard complex were incorporated into this new building complex and continued to be used (Colquitt 1913:104, 140). Gateways opened to the north onto Houston Street, south onto Alamo Plaza, and east into a smaller area in front of a line of hay sheds and produce storage buildings, some of which were probably also originally built by the army (Sanborn Map and Publishing Company, Ltd. 1885). Major changes to the convento building were completed by 1878 . 
Upon Grenet's death in February 1882, George Kalteyer was appointed executor of the estate (Colquitt 1913:34). Kalteyer sold the Grenet Alamo store to Charles Hugo and Gustav Schmeltzer in December 1885 (Colquitt 1913:38). Hugo and Schmeltzer continued the business as established by Grenet, the wholesale and retail sale of groceries, wines, and liquors. They apparently did little to alter the structure of the store.

The state of Texas purchased the old convento building from Hugo and Schmeltzer in January 1905 (Colquitt 1913:64). The state had already bought the Alamo church building in 1883 (Habig 1968:72). These two properties were entrusted to the DRT for restoration and curation. In 1911 the state appropriated $\$ 5,000$ for the restoration of the Alamo buildings, and work began under the direction of Oscar B. Colquitt, governor of Texas. The galleries and other woodwork were removed and, by March 1912, the roofs, sheds, and all other recently added wooden structures had been demolished, leaving only the stone walls along the west and south sides of the building standing (San Antonio Express [SAE], 3 March 1912). The old foundations of the eastern walls of the Long Barracks and some other convento buildings were traced by trenching and reconstruction of these walls began in 1913. By July 1913, the eastern walls of the present Long Barracks building stood to a height of about six feet ( $S A E, 1$ July 1913). The army maps and drawings of 1846-1849 were used as the basis for the restoration of doors and windows on the western facade of the convento, probably aided by visible traces of the old openings filled with more recent stonework.

Governor Colquitt had originally intended to restore the structures to their appearance in 1836 , including the second stories of several convento buildings; however, appropriations ran out before the job could be completed. All remaining masonry above the present wall top was removed around 1915 (Ables 1967: 411-412).
The renovation of 1905-1915 included the construction of a low wall along the south side of Houston Street. This wall was made of loose stone, much of it probably left over from the removal of the various unwanted portions of the Hugo and Schmeltzer store. In December 1926, this wall was replaced by a higher stone and cement wall (SAE, 8 December 1926; 19 December 1926). The latter was in turn modified to some extent in the 1930s, and built to its present length around the Alamo Park as the remainder of the block was purchased by the DRT.

\section{Previous Archaeological Investigations}

Two previous investigations had been undertaken within the second patio. In June 1966, the State Building Commission sponsored excavations conducted by the Witte Memorial Museum under the supervision of John Greer (1967). Of the numerous excavation units investigated in this project located between the north wall of the chapel and the north wall of the second patio, two were of particular interest to the current investigation. In the eastern half of the patio (10-20 ft from the north patio wall), from 1.5-5.5 $\mathrm{ft}$ of rubble, identified by the excavators as a wall or foundation trench, was found (Greer 1967:51). Several occupation surfaces and layers of cinders were also recorded. Area B (midway between Area A and the west wall of the patio and the same distance from the north wall) revealed the same stratigraphy, including the wall foundation, as in Area A (Greer 1967:5-61). This unit also yielded a concentration of 1836 artifacts including gun parts, musket balls, and gun flints. Another interesting feature found during these excavations was the foundation of a large adobe room in the south, or well, patio. The alignment of this foundation did not agree with those of the surrounding buildings. Datable stratigraphy above this feature suggested it predated the present chapel (Greer 1967:91). 
In spring 1973, Mardith Schuetz conducted excavations for the DRT at the southeast end of the courtyard. An area ca. $40 \times 25 \mathrm{ft}$ was excavated to an average depth of 35 inches. Four occupation levels were observed (Schuetz 1973).

Level 1 was dated by Schuetz to ca. 1905 , when DRT maintenance began. Level 2, containing black soil and layers of cinders, represented the era of civilian occupation of the site. Level 3 included a pavement of caliche and gravel from the occupation by the U.S. Army, dated by an array of military artifacts of the period. Level 4, consisting of loose brown soil containing Spanish colonial ceramics and other artifacts, was generally about two feet below the present surface. Two perpendicular stone wall foundations, which aligned with the presently restored walls, were uncovered in this area. Schuetz observed no indications of the fortifications described by Sánchez-Navarro and others anywhere in her excavations.

Each of these excavation projects produced information valuable in planning the present project. Archival documents not available when the earlier excavations were conducted helped in reinterpreting the earlier data.

\section{Methodology and Results}

Considerable historical research and careful planning were carried out prior to the initiation of fieldwork in order to obtain the maximum amount of information from the excavation. Decisions on unit placement and evaluation of artifacts and features found during the excavations were based on the historical information.

As previously discussed, fieldwork was done in two phases. In Phase I, test units were located to provide information about specific architectural features, as well as general information on the construction of the north wall of the patio (Figure 5). Unit A was placed so as to cross the back wall of the Grenet/Hugo and Schmeltzer store. Units B and $C$ were located where we postulated the east and west sides of the entrance gate in the wall once stood. Unit D was planned to cross the location of the inner wall of the warehouse structure which stood inside the north wall and to reveal whether there had been a Spanish building beneath the nineteenth-century warehouse. Unit $\mathrm{E}$ was located so as to cross the postulated line of the east wall of the original Spanish convento.

Based on Phase I excavations, we decided to concentrate on the area immediately west of Unit E during Phase II excavations. This area was selected as the one of greatest interest because so many structures and property lines had cornered here through the history of the mission, and any damage done by present construction might well destroy critical information. In addition, we hoped an explanation would be found for the many enigmatic features seen in Unit $E$.

To correspond as much as possible to the work done in 1966 and 1973, measurements were made in feet and inches. To avoid confusion, measurements included in this report are presented in English rather than metric units.

In total, seven separate units were excavated to sterile soil at $40-48$ inches. All soil was screened through 1/4-inch mesh, except where noted in this report, and standard archaeological procedures were followed in all field and laboratory work. Detailed methodology and results of the excavation are given in the following sections.

A log of all work in progress was kept by the field director, with more detailed individual descriptions done by each excavator when necessary. Sketches, profiles, and plans were made of all excavation units and a complete photographic record was kept in both black-andwhite prints and color slides. 


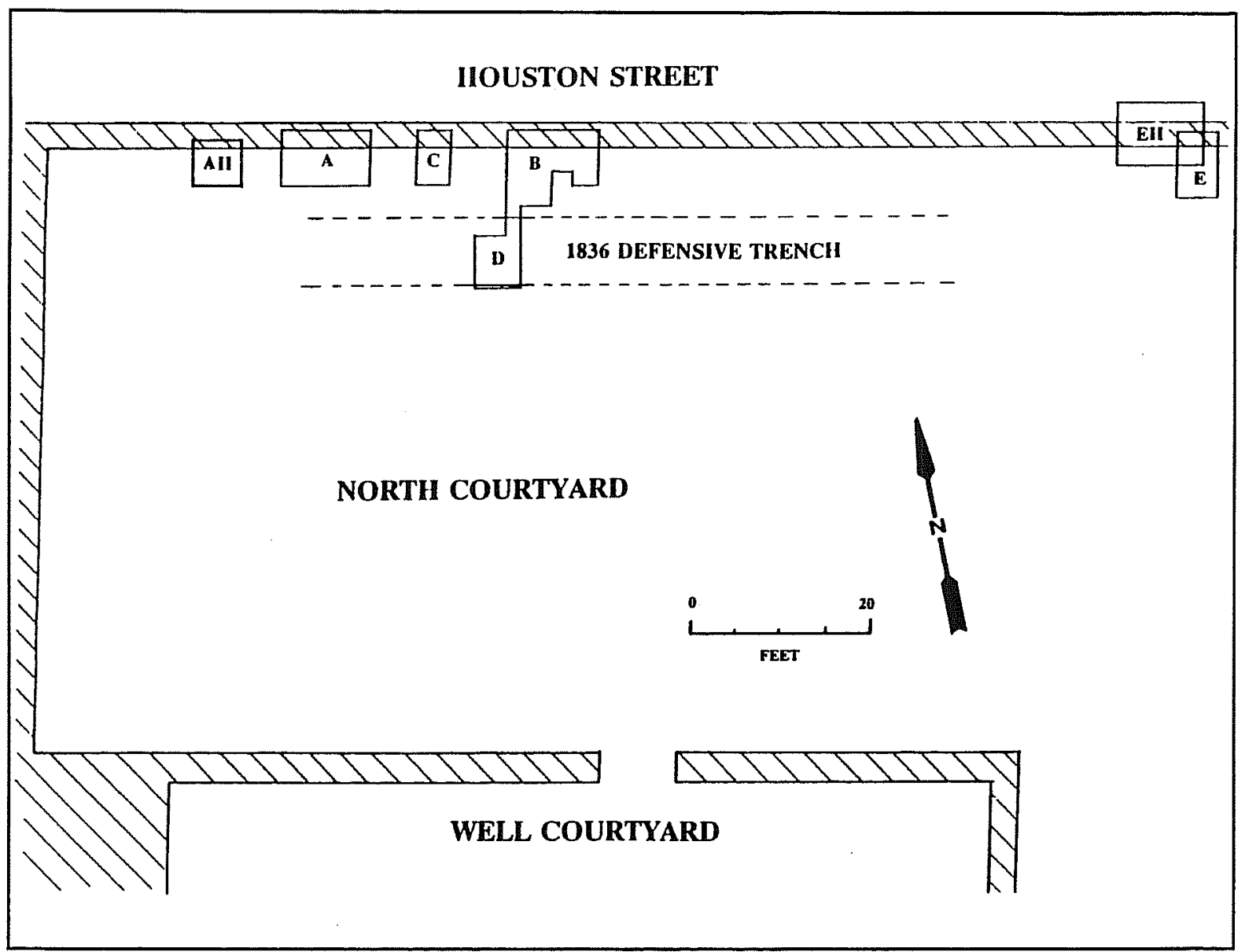

Figure 5. Excavation units at the north wall in the north courtyard.

Cultural material was transported to the CAR laboratory for processing and analysis. Artifacts, field notes, drawings, photographs, maps, and research materials are on file at the CAR laboratory.

\section{Phase I Excavations}

\section{Unit A (Figure 6)}

Unit A was a 4-x-10-ft trench along the south face of the wall (Figure 5), laid out to include the northeast corner of the Grenet store building. This unit was excavated in four sections, designated A-1, A-2, A-3, and A-4. Below 24 inches, the sections were combined into Unit A-1-4.
Based on previous excavations, the first 12-14 inches were expected to consist of late fill brought in during landscaping activities in the early twentieth century. Excavation and examination of a section of the trench revealed the first six inches consisted of dark gray-brown fill, while the following 12 inches were made up of a red-brown clay soil which filled an intrusive pipe trench. Fragments of broken ceramic sewer tile confirmed the original reason for the trench. We decided to remove and discard, without screening, all the gray-brown fill and the red-brown soil directly beneath it. The soil changed at the bottom of the red-brown pipe trench to a gray, ashy loam which contained Spanish colonial artifacts, charcoal, and bone. 


\section{UNIT A}

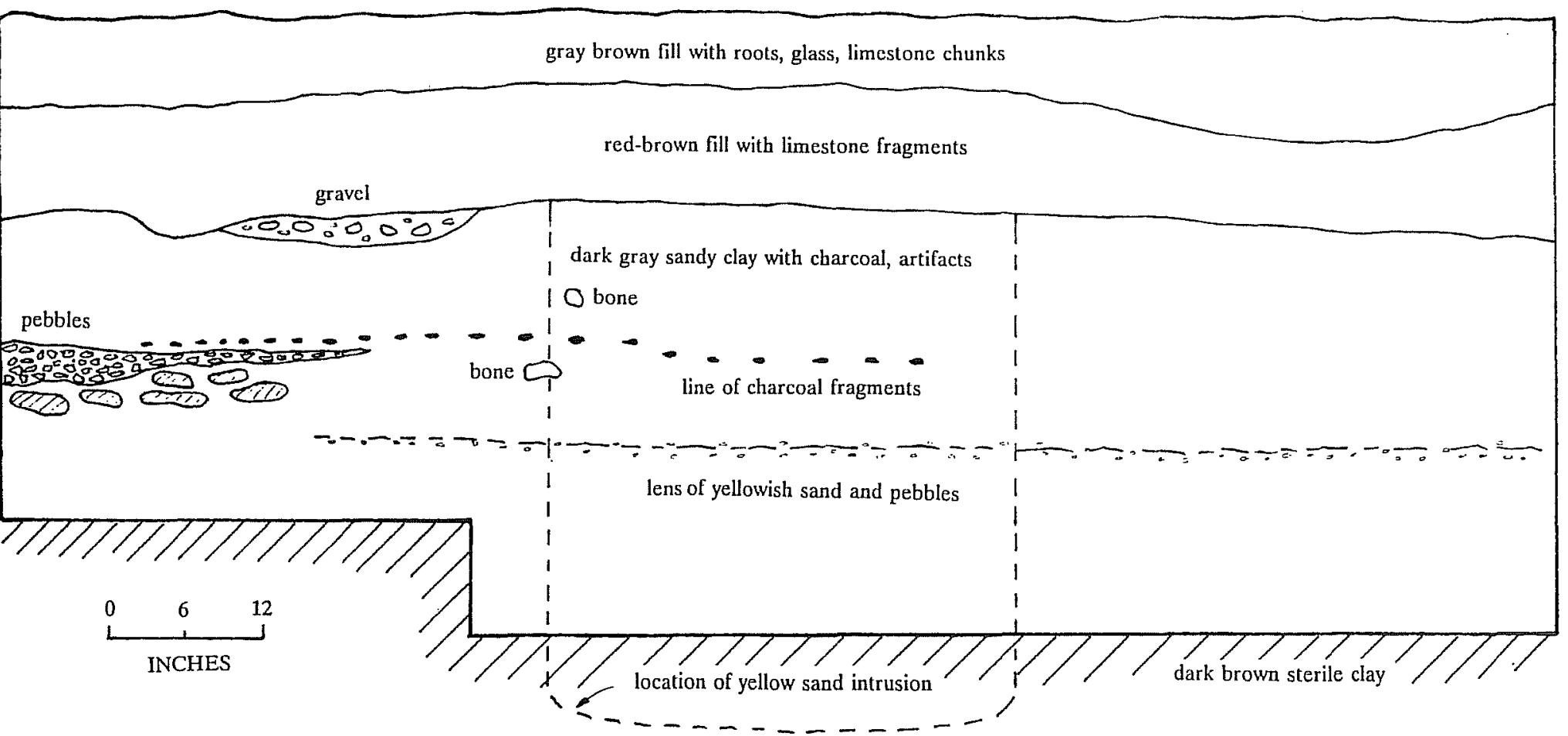

Figure 6. Unit A, south wall profile. 
In the center of the unit, a three-square-foot area of yellow sandy material containing chunks of whitewashed plaster, cut nails, window glass, wine bottle fragments, and other late nineteenthcentury material was found. This material was also present in an 8-10 inch band along the face of the wall. Large chunks of asphalt paving were also found in this deposit. The deposit extended beneath the bottom of the present wall from a depth of 30-56 inches, at which point sterile dark brown soil was found. Surrounding the yellow sandy intrusion, the gray ashy soil continued to 48 inches before sterile soil was reached. To the east side of the yellow sandy area, the present wall was found to rest directly upon the gray ashy Spanish-period deposit; test probes beneath the bottom of the wall found no evidence of prior wall footings or disturbance of the Spanish levels below the bottom of the present wall at 28 inches. An interesting detail observed in the south wall profile was a remnant of cobblestone paving which appeared to stop just short of the east line of the yellow sandy intrusion.

\section{Unit B (Figure 7)}

Unit B, located on the south side of the wall, $15 \mathrm{ft}$ to the east of Unit A (Figure 5), originally measured $4 \times 10 \mathrm{ft}$. Later extensions, designated B-2, B-3, and B-4, were added to the south to test an area undisturbed by pipelines.

The first nine inches, which were not screened, consisted of the same dark gray-brown fill found in Unit A. Just below this was a thin layer of caliche-like material, containing cut nails, which covered the entire unit. The next level was medium-brown soil, below which was a thin layer of caliche which overlay a hardpacked cobblestone pavement similar to the remnant found in Unit A. Beneath this was the same gray, ashy loam containing Spanish-period artifacts which had been observed in Unit A. This gray soil continued downward to sterile dark brown clay at 39 inches, interrupted by several bands of lighter gray soil containing chunks of plaster, charcoal, and bone. An especially heavy deposit of this plaster debris rested directly upon the sterile soil at the bottom of the unit.

The same yellow sandy band with latenineteenth-century artifacts was encountered along the north wall of Unit B as was found in Unit A. Also present was a north-south trench containing a five-inch diameter iron pipe, which was excavated from a point just below the first caliche layer beneath the recent fill. The disturbance of this trench was evident in the wall of the excavation and caused considerable mixing of artifacts to a depth of 30 inches. A pipe trench, containing ceramic sewer pipe fragments and excavated from approximately the same level, crossed this excavation unit east to west just inside the north wall. It was filled with the same red-brown fill as found in the trench in Unit A.

In the approximate center of Unit B, directly beneath the red-brown trench fill, was a circular disturbance of roughly 24 -inch diameter. This feature was found to be a deep intrusion (the bottom was 59 inches below datum) filled with loose clay loam that contained both cut and wire nails, fragments of wood and mortar, iron hardware pieces and bottle fragments, as well as a few ceramics and handmade brick fragments from the Spanish-period soil which it had penetrated.

\section{Unit C (Figure 8)}

Unit $C$ was a four-foot square against the north wall between Units $A$ and $B$, five feet east of Unit A (Figure 5). When the gray-brown fill had been removed, it was apparent this area had been disturbed. A layer of loose rocks from 6-12 inches contained both eighteenth- and nineteenth-century artifacts and, at 15 inches, a ceramic sewer pipe was found to run east-west across the center of the unit. Directly beneath this disturbance, at 20 inches, an iron pipe was found to run north-south. At this point, since it appeared that little of the area would be undisturbed, the unit was recorded and refilled. 


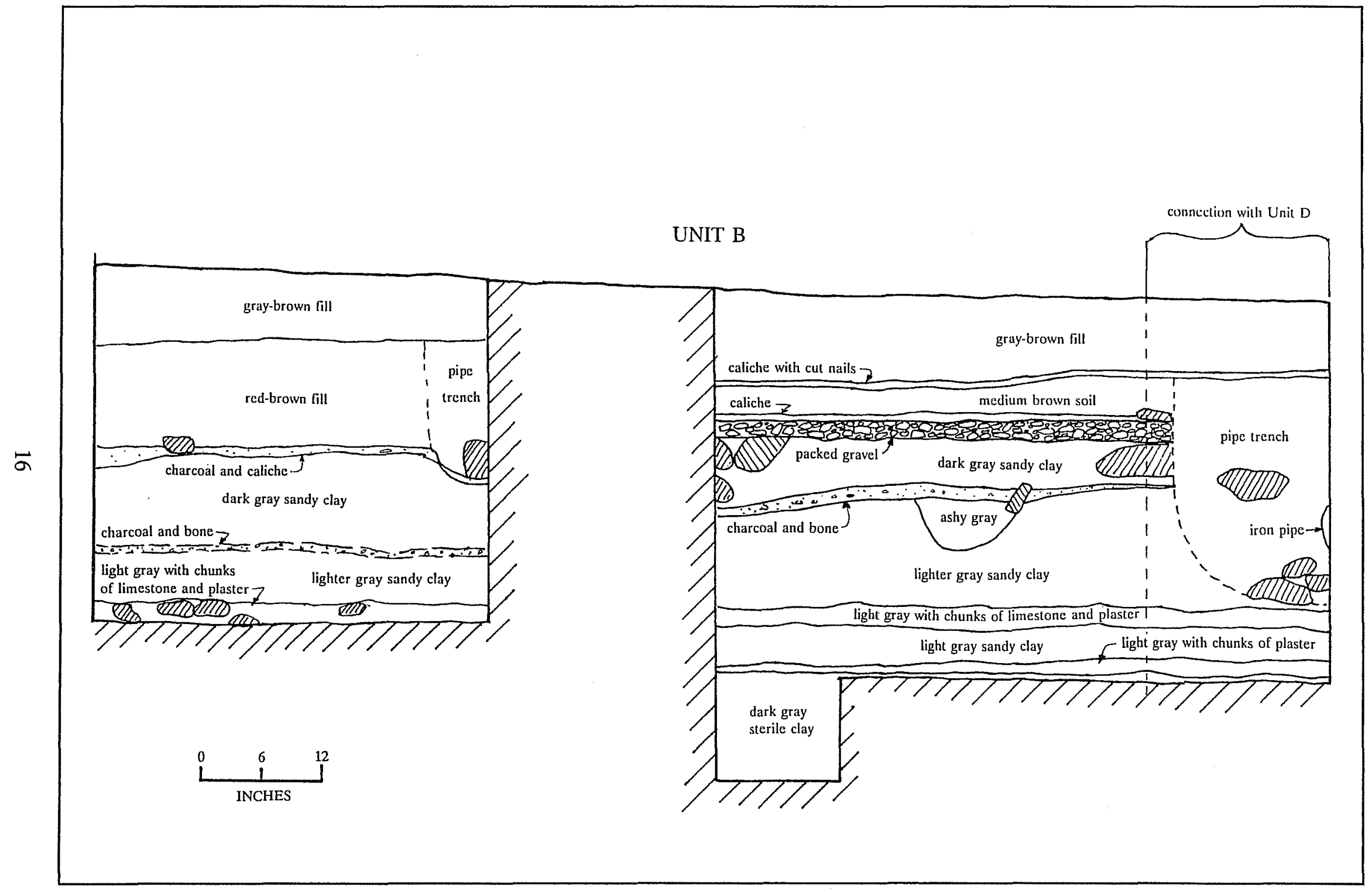

Figure 7. Unit B, south wall profile. 


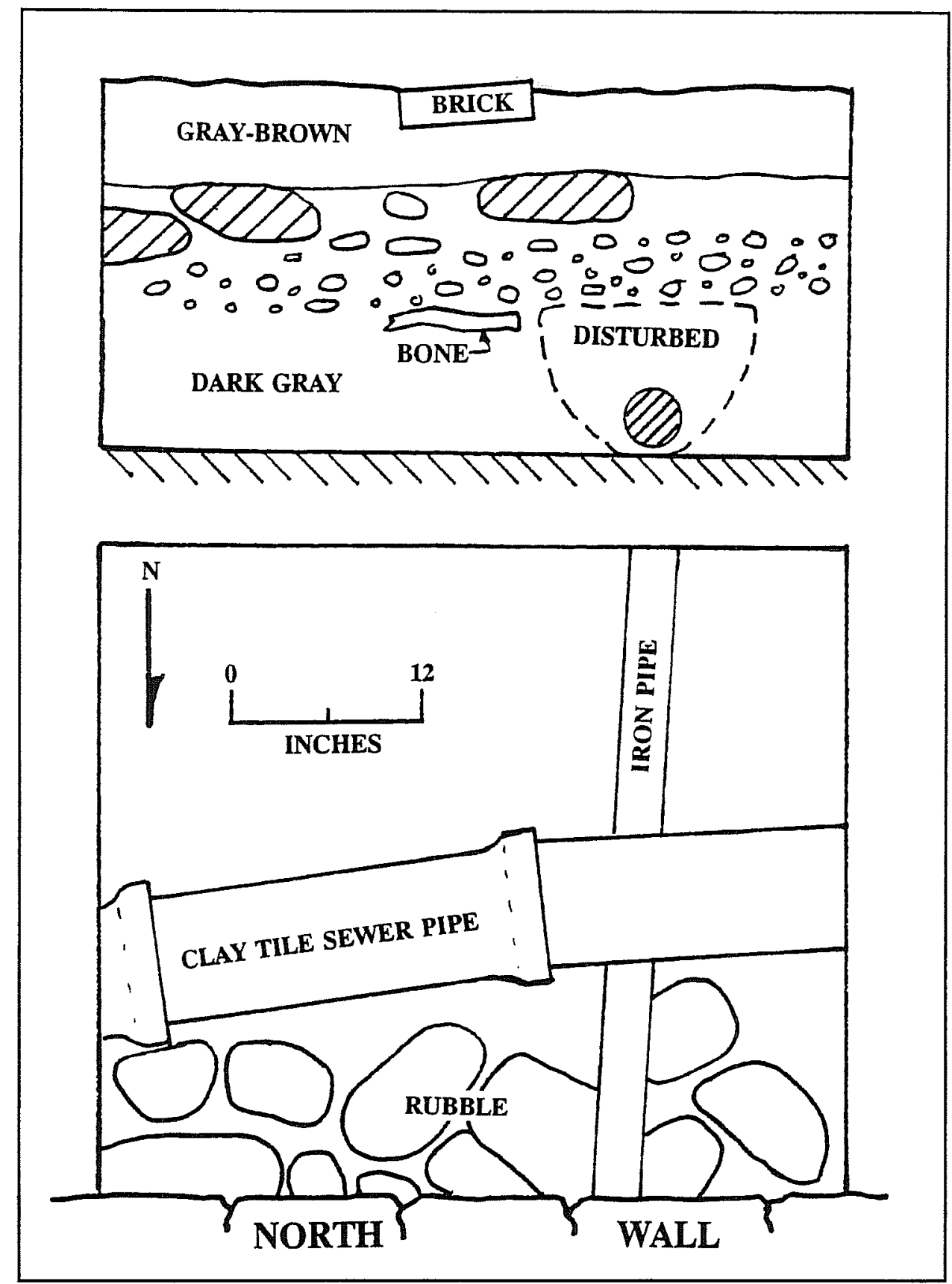

Figure 8. Unit C. Top: south wall profile; bottom: plan view.

The soil from this unit was not screened, but a representative sample of the artifacts was recovered.

\section{Unit D (Figure 9)}

Unit D was originally a 6-x-6-ft unit laid out across the area where previous work in 1966 had located what appeared to be the footing of a wall which ran east-west about $12 \mathrm{ft}$ south of the present north wall of the patio (Greer 1967:5-6). Additional sections-D-1, D-2, and D-3-were added to join with Unit B.

The purpose of the investigation was to obtain information for dating this wall and to determine if earlier, mission-related or 

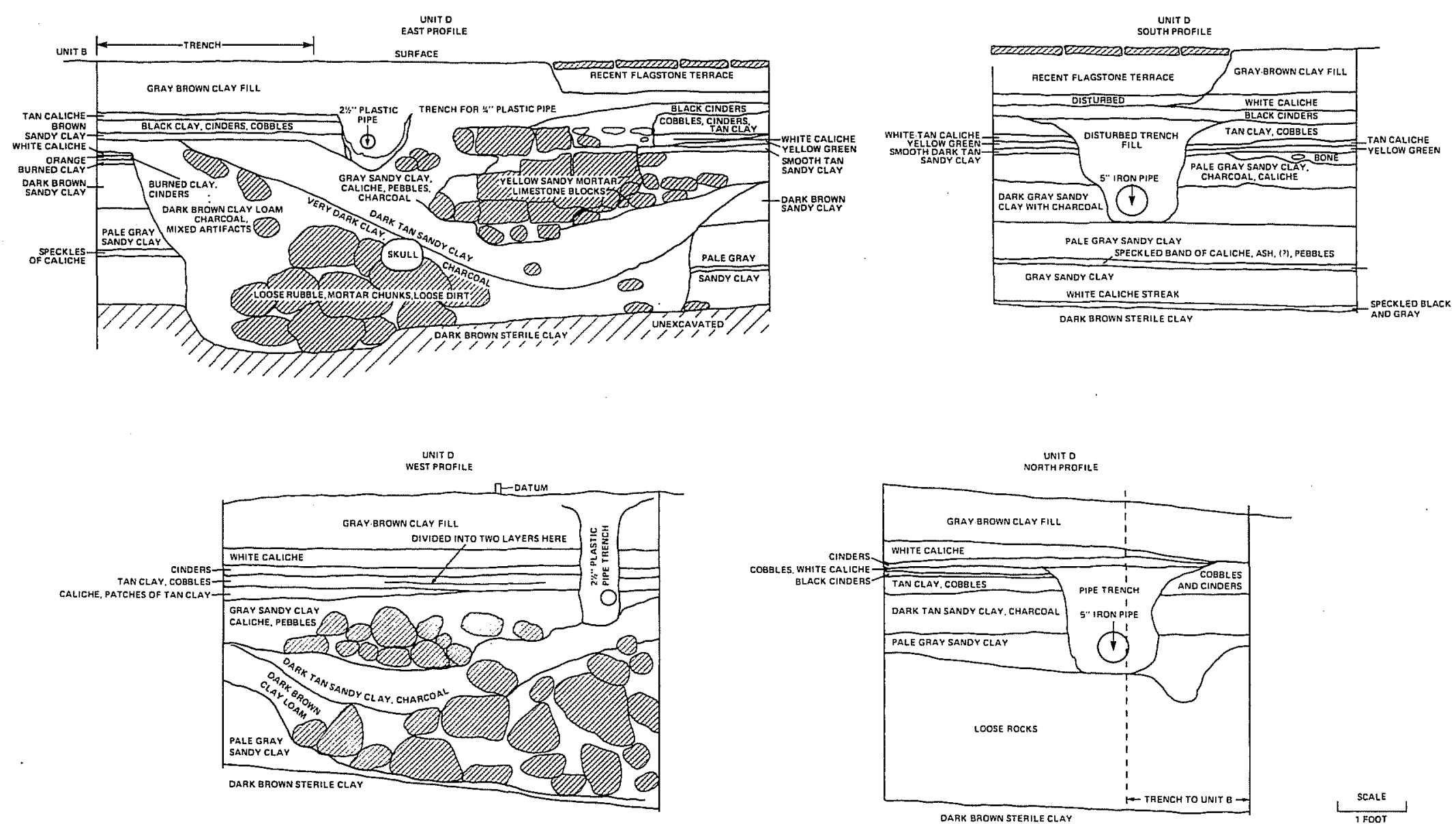

Figure 9. Unit D, east, south, west, and north wall profiles. 
battle-related structures were located in this area. The unit was excavated in stratigraphic levels wherever possible.

The first 12 inches of the unit consisted of graybrown fill grading to a light tan caliche. This level contained late-nineteenth-century artifacts and two plastic water pipes which crossed the unit. A dense layer of cinders-containing numerous cut nails and rusted iron fragments, pieces of bottle and window glass, and a crown bottle cap-was located at 12-14 inches. Directly below the cinder layer was a three-inch level of cobblestones set in dense tan clay. Upon and within this pavement were cut nails, bottle glass, and ceramics indicative of a latenineteenth-century deposition, as well as a few Spanish-period ceramic sherds mixed in from the deposits below. The east half of this level was interrupted by the intrusion of a pipe trench which ran north-south, and an area about $30 \times 30$ inches of yellow sandy mortar, in the center of which was a 12-x-18-inch intrusion of the gray-brown fill from the level above. The yellow mortar appears to be related to the construction which took place when Grenet remodeled this area for his store in 1877 .

A gray, sandy clay which contained early nineteenth-century whiteware sherds, cut nails, Spanish-period ceramics, and fragments of brick and mortar was found at 17-24 inches. A mass of limestone rocks was encountered running east to west across the center of the unit. The western half of this accumulation was composed of unshaped rocks packed in gray clay. The eastern half of this feature was found to be a wall footing of shaped limestone rocks set in a dense yellow sandy mortar. The abovementioned dark gray brown intrusion stopped on the top of a flagstone set into the west side of the wall footing at the 19-inch level. Beneath this was another flagstone, set in the same yellow mortar, which rested on top of a fiveinch iron pipe in the bottom of the pipe trench described above.

The remainder of the unit was composed primarily of limestone rubble in loose, dark brown, loamy soil, except for an area along the south edge of the unit which consisted of layers of gray, sandy clay containing a few sherds of Spanish-period ceramics. Sterile, dark brown soil was reached at approximately 49 inches.

Occasional sherds of early nineteenth-century ceramics and glass, and numerous sherds of Spanish and Indian pottery were included in the fill which surrounded the limestone rubble. Several musket balls, a gunflint, and the cock from a flint lock were also present in the lower levels. Several of these objects were found to be at or near the contact of the rubble fill with the gray sandy feature at the south end of the unit. Also found within the rubble, at 33-38 inches, was the cranium of a human skull. No teeth or lower jaw were present, nor were any postcranial bones found in conjunction with the skull or anywhere in the unit.

That we had dug into the southern portion of some ditch-like feature, the northern limits of which were outside the unit, became obvious as Unit D was completed. We drew a set of profiles of the unit as excavated, then cut a 1.5-ft-wide trench from the northeast corner of Unit D to the southwest corner of Unit B. This trench was dug to the sterile brown clay with no screening of the earth removed.

The east face of this Unit D-Unit B trench was cleaned and profiled, and the profile sketch added to that of the east face of Unit D. This completed profile drawing conclusively showed a large ditch with nearly vertical sides and a roughly flat bottom running east-west through Unit D and the added trench to the north. This ditch was about seven feet wide north to south, and its bottom was $3.8 \mathrm{ft}$ below the present surface. The profile revealed the ditch had been dug from some higher surface, and had been filled with several layers of dirt and rubble; then some number of inches of the upper part of the ditch and fill were removed, leaving a flat surface which was then paved with tan clay and cobbles. No clues which could reveal how many inches of original deposition were removed in 
this leveling process were disclosed in the profile.

That the trench showed up in Areas A and B of the 1966 test excavations (Greer 1967:5-6), which were in line with and on either side of our Unit $\mathrm{D}$, confirms that this feature continued to the west and east. Identification of the feature as a defensive trench was suggested by the location of such a feature on the Labastida map (Figure 4).

\section{Unit E}

Unit $\mathrm{E}$ was a $5-\mathrm{x}-5-\mathrm{ft}$ unit, consisting of two sections: $\mathrm{E}$ and $\mathrm{E}-1$. The unit was laid out across one possible line of an extension of the eastern wall of the convento. The purpose was to determine if a wall had been in existence here at any time during the mission period or later and, if so, how it had been constructed.

As in the other excavation units, the layer of recent fill was removed without screening, in this case to the 12-inch level, at which point the red-brown fill of the sewer pipe trench began. Above this level, two iron water pipes had been encountered. The cinder layer found in the other units appeared here at 12 inches, below which was 12 inches of tan clay containing latenineteenth-century rusted metal, glass, brick, and whitewares. At 24-28 inches the cobblestone layer appeared. Beneath this level, the deposits divided into three distinct sections. An area in the center approximately 33 inches wide consisted of an adobe-like material of hard, tan clay containing chunks of caliche. To the west was an area of brown, sandy clay containing Spanish-period artifacts, bone, and charcoal. To the east was a soft tan sandy clay which contained fewer Spanish-period artifacts and no charcoal. An animal burrow disturbed this area and the central feature, which could account for a few whiteware sherds present in this deposit.
At 34 inches we decided to remove the southern half of the unit to obtain a cross section of the central feature and to examine its relationship to the surrounding area. Sterile, dark brown clay was found to slope downward to the north and west at ca. 36-50 inches. On top of this brown clay, and with the same slope, was a hard layer of white, sandy, lime mortar, varying in thickness from 1-3 inches. Beneath the adobelike surface, 2-3 inches thick, were several layers of ash, charcoal, and bone, which directly overlay the sterile clay subsoil and the white mortar.

The western section of the unit was found to drop into a ditch-like feature running north and south, the limits of which were outside Unit E. At the end of Phase I, the true nature of the ditch, the adobe surface, and the other associated features remained unclear.

\section{Phase II Excavations}

\section{Unit EII (Figure 10)}

A jackhammer was used to remove a section of the 1926 wall foundation and the adjacent sidewalk on the north, making an opening of $9 \mathrm{ft} 8$ inches east-west and $7 \mathrm{ft} 3$ inches north-south. All loose rubble was removed from the 1926 wall trench and from the yellow sand used as bedding material beneath the sidewalk, and the area was cleaned. It was immediately obvious that the rubble in the area just west of Unit $E$ was not a wall, but rather a rubble zone several feet wide with no well-defined limits.

We began removal of this rubble from the southern half of the unit, and found it was 20-24 inches thick and 70-75 inches wide. Its upper surface was 22 inches below the north courtyard ground surface. Several of the stones were nearly two feet long, but all were randomly placed, with a sticky, tan, sandy clay between them. This clay had a high content of charcoal flecks and a few artifacts, including early nineteenth-century whitewares. 


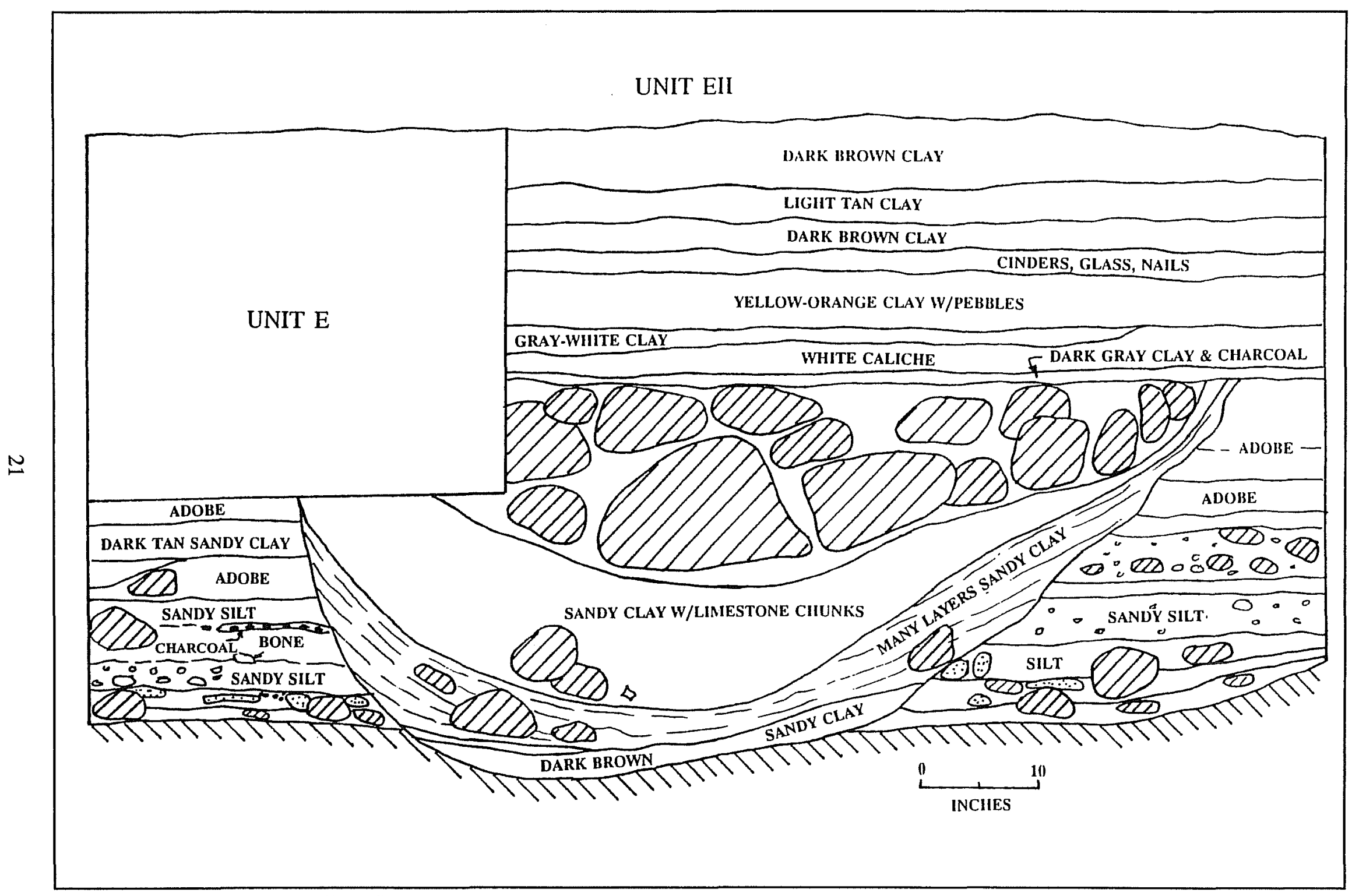

Figure 10. Unit EII, south wall profile. 
Beneath the massive stone rubble, the brown, sandy clay containing charcoal and a few Anglo-American artifacts continued to a depth of 50-55 inches below the surface of the north courtyard. This component had no massive stone, but had a large quantity of cobbles and chips of limestone and numerous rocks about 3-5 inches in diameter. Beneath this was a soft, light $\tan$ clay with a great deal of fine sand content. Few artifacts were found in this layer, but numerous animal bones were collected. The few artifacts were entirely Spanish-Mexican in origin. This soft, sandy clay filled a trough-like depression into the dark brown, sterile clay which underlies the area. As work continued, it became obvious this depression was a smoothly rounded ditch about $6.5 \mathrm{ft}$ wide running roughly north-south, and the various layers of clay and rock described above had filled it. Reexamination of the drawings of Unit $E$ showed the ditch-like feature found along its west side was actually the eastern edge of the round-bottomed ditch found in Unit EII.

The southernmost portions of Unit EII flanking this ditch showed a complex and confusing stratigraphy. The dark brown basal clay itself sloped down towards the south. In fact, Unit EII exhibited characteristics in its southwest corner very similar to the characteristics found in the southeast corner of Unit E, including several patches of white, sandy mortar on the surface of basal clay and multiple thin strata of gray clays, charcoal, and ash above it and below a hardpacked adobe surface.

As these layers were removed, we realized we had the remains of two ditches, one dug through the other. The rubble-filled ditch excavated first cut across a lower ditch dug at a much earlier time, and this ditch ran in a northeast-southwest direction.

The lower ditch was broad and shallow and extended into the dark brown clay, which was the original ground surface. The small section uncovered in Units $E$ and EII is about seven feet wide and approximately 18 inches deep as it survives in the ground. This ditch, which ran about $\mathrm{S} 74^{\circ} \mathrm{W}$, was filled by a series of widely varied lenses of material, none of which appeared to be water deposited; therefore the fill is assumed intentional. On the surface of the brown, basal clay in the bottom of this lowest ditch we found a copper alloy spoon with a pewter plating; part of a green-decorated majolica bowl; and a large fragment of a majolica bowl decorated in the style called Puebla Polychrome, dating to ca. 1675-1700. These and other artifacts from the various lenses indicate the ditch was probably filled in the early 1700 s.

In the southwestern corner of Unit EII, we recognized a row of adobe blocks set into a hard-packed adobe surface which capped the multiple strata filling the lower ditch at 21 inches below ground surface. Following the hard-packed surface (apparently a puddled adobe floor) to the west, we found it ended against one of the stone walls found in the stockade trench, about $10 \mathrm{ft}$ from the row of adobe blocks. Both walls ran at an angle about $15^{\circ}$ off the general plan of the entire church and convento complex. The adobe floor was found throughout Units E and EII at this level, on both sides of the row of adobe blocks.

In the north half of Unit EII, we found that the cinder bed and hard-packed layer of white caliche, found in most of the rest of the north courtyard, formed the surface beneath the yellow sand bedding of the sidewalk. The caliche, however, was very thin and patchy and the cinders were about six inches lower than the cinder surface within the north courtyard. Below these two layers was a bed of brown clay, cobbles, and caliche. Beneath this and east of the round-bottomed upper ditch was a series of undisturbed strata which finally gave us a chance to work out the relative dating between the various features.

Running east-west along the lines of the 1926 wall were two other wall trenches at a lower level. These were accompanied by two lines of postholes, each apparently associated with one of the wall trenches. One of these two trenches 
was directly below the 1926 wall, with its north face even with that of the 1926 wall. A large, well-trimmed, saw-cut limestone block, $20 \times 18$ $\mathrm{x} 18$ inches, was found set into a yellow, sandylime mortar in this trench. The mortar was similar to that found in abundance in the foundation trench of the Honore Grenet store, located in Units A and AII. Other than this cut block, the two ditches in Unit EII contained nothing but rubble and fill. Both ditches and posthole lines date after the upper ditch fill, and all contained Anglo-American artifacts.

\section{Unit AII}

In the area of a north-south wall fragment found just west of Unit $A$, a second section of the 1926 wall and sidewalk was removed and the area excavated. Unit AII was a 6-x-5-ft unit, the east edge of which was $2.75 \mathrm{ft}$ west of the west edge of Unit A. The stratigraphy was virtually identical to that seen in Unit A. We determined the wall foundation in this area was of eighteenth-century date (probably after 1750), built into an intrusive footing trench from a higher level, now destroyed. Within the limits of the unit we could not determine whether the wall was late Spanish or Anglo-American. The wall presumably reached as far north as the footing trench for the Honore Grenet store north wall, but definitely went no further north. The Honore Grenet wall was found to be $2 \mathrm{ft} 5$ inches wide and to reach to a depth approximately 60 inches below the surface of the courtyard. The outer face of the wall was even with the outer face of the 1926 wall.

\section{Stockade Trench \\ (dug to construct the stockade wall)}

The south face of the stockade trench was cleaned and scraped and a complete profile drawn. In the course of this work, traces of three walls were found extending toward the north. Two areas of rubble, believed to be walls, were also located. One of these was immediately adjacent to the west edge of Unit $\mathrm{E}$.
At a distance of $11 \mathrm{ft} 8$ inches west of the edge of Unit E along the stockade trench, just west of the stone wall associated with a adobe wall and floor found in Unit EII, traces of an apparent footing trench running east-west were found. These traces, seen along the north face of the stockade trench, consisted of fist-sized rocks and dark gray clay in a thin deposit on this face. This deposit was lower than the disturbed area associated with the 1926 wall, and distinctly different from the light gray soil found elsewhere in the stockade trench at this level. Removal of this deposit showed the light gray background soil behind it. Apparently the excavation of the stockade trench removed the majority of this footing trench, leaving only 2-3 inches of the northern side of the trench in the ground. The traces curve upward abruptly toward the east of a point $11 \mathrm{ft} 8$ inches west of Unit EII, and from that point west, the traces slowly merge with the footing of the 1926 wall.

Eight feet from the west face of unit EII, a second north-south wall foundation was found in the stockade trench south profile. Upon detailed examination, this wall was found to extend at right angles to the 1926 wall and to be the lower section of a footing trench filled with the remains of a stone wall built from some higher surface no longer in existence, similar to that found in Unit AII. This is a substantial wall, $2.5 \mathrm{ft}$ thick at its foundation. No other details could be determined about this wall within the limits of the stockade trench.

\section{Wall Trench}

After the completion of our limited additional testing, the remains of the 1926 wall foundation were removed by construction workers. We conducted constant monitoring of the removal, resulting in the collection of additional information.

The large, square limestone block set into yellow, sandy mortar in the wall trench directly below the 1926 wall was duplicated at intervals averaging about $9 \mathrm{ft} 10$ inches, center to center, 
westward down the trench for seven blocks. At each position, a rectangular bed of yellow mortar was found in the north face of the 1926 wall trench. The last block trace was ca. $30 \mathrm{ft}$ from the east end of the Honore Grenet store north wall. The 1926 wall foundation gradually deepened toward the west, and was probably deep enough beyond the seventh block to destroy traces of any blocks located further west. The postholes apparently associated with this wall line are also at about $10-\mathrm{ft}$ intervals, but are offset to the west of the stone blocks by about eight inches. No examples of these postholes were seen west of Unit EII, but the bottom of the 1926 wall trench was covered with hard-packed rubble and dirt and could have concealed any number of postholes. Because time did not permit more than a very brief examination of the entire trench, a number of features were undoubtedly overlooked.

The postholes associated with the northernmost footing trench were found regularly at about eight-foot intervals, center to center, slightly outside the 1926 wall trench. They were located by shovel tests into the north face of the 1926 trench at measured intervals. The post molds measured five inches in diameter, the postholes (not all of which were discernable) 12 inches. Five postholes were located, including two in Unit EII. An additional post was found four feet west of the last of these northern wall trench posts. This post was three inches in diameter, and had been cut in half vertically by the 1926 wall trench. It extended only 26 inches into the ground, while the 1926 trench in this area was 34 inches deep. If a similar post had been placed every four feet between the larger, deeper-set posts, most of them would have been destroyed by the later trench.

The wall foundation at right angles to the 1926 wall apparently ended at the footing trench line containing the stone blocks, but not at a stone block. It is uncertain whether the east-west trench simply cuts off the end of the north-south wall or whether the two join at that point.

\section{The Artifacts}

Numerous artifacts typical of the Spanish occupation in the eighteenth century, the early to middle nineteenth-century military occupations, and the late nineteenth-century commercial establishments on the site were recovered in the archaeological excavations. Detailed descriptions of pottery types and other artifacts found during previous excavations on the Alamo grounds are available in Fox et al. (1976), Greer (1967), and Tunnell (1966). Therefore, a less intensive approach to artifact descriptions is used in this report, concentrating upon unique objects and those important for dating and/or interpretation of the various deposits and features encountered in the excavations.

In the previous description of the excavation units, reference was often made to ceramics or other artifacts as being typical of the eighteenthcentury Spanish or nineteenth-century AngloAmerican occupations. The following discussion differentiates between artifacts typical of each time period and shows how these have been used to determine dates of the archaeological deposits.

\section{The Spanish Colonial Period}

Diagnostic artifacts of the Spanish colonial period are generally dominated by ceramic sherds. Many ceramic vessels were imported by supply train from Mexico. Also imported during the Mission period were copper vessels, religious medals, crucifixes, jewelry, metal knives, scissors, spoons, buttons, and buckles. Some of these articles were brought for use by the Spanish, others for distribution to the Indians.

Indian-made pottery, chert tools, projectile points, and lithic-manufacturing debris are generally plentiful on sites of this period. Fragments of handmade bricks occur throughout the deposits, probably representing a local 
industry taught to the Indians by the padres. Adobe blocks were also used, particularly in the earlier stages of mission construction.

The most interesting and diagnostic artifacts recovered from the excavations are illustrated and described in some detail below.

\section{Ceramics}

Indian-Made Earthenwares

The predominant type of locally made pottery is a bone-tempered, low-fired ware which appears to be descended from the ceramics made by peoples of south Texas before the Spanish arrived (Fox et al. 1976:67). This is generally called Goliad ware (Figure 11p) when found in a historic context. A few sherds of pottery from other areas, such as the Coastal Bend and east Texas, are often found in mission collections, probably reflecting the presence of Indians from these areas at the mission. Two such sherds (Figure 11n, o) found during these excavations have been tentatively identified as Goose Creek Incised ware, made by Indians in the Galveston Bay area (Suhm and Jelks 1962:55).

\section{Imported Earthenwares}

The most common imported ceramics on eighteenth-century Spanish sites in the San Antonio area are lead-glazed redware bowls and ollas from Mexico (see Fox 1974). Although numerous variations and subtypes exist, these redwares can be separated into two distinct groups: a thick (.24-.5 inches), sandy paste ware; and a thinner (.08-.06 inches) ware with a finer-textured paste. The latter is often painted with dark brown, cream, and green floral designs. Both types were common in these excavations. Sherds of black-glazed lusterware and wheel-made unglazed ware, some of which bear bands of red ochre paint, were also present. A few sherds of a red burnished ware and a gray slip-painted and burnished ware made in Tonalá, Jalisco, were also present (Figure 111).
On every Spanish site are found at least a few sherds from large, heavy containers known as olive jars. These generally have a white slip and/or green glaze on one or both surfaces. A few sherds of this type were recovered in the excavations.

\section{Majolica}

Deep soup plates, cups, and bowls with a soft, absorbent paste coated with a vitreous, opaque tin enamel were regularly brought to the Spanish establishments in the borderlands. The brightly colored designs on these vessels apparently changed with the fashion of the times and can, in some cases, be used to establish or confirm the date of a deposit within which the sherds are found. Decorative types found in these excavations were as follows:

1) Puebla Polychrome-a distinctive bright blue combines with dark brown/black lacy patterns (Figure 11c, d) to make this ceramic design unique and easily recognizable. According to Goggin (1968:180), this type was made during the last half of the seventeenth century. Snow (1965:32) extends the date for this type to 1725. Its presence generally indicates an early deposit in San Antonio, since it appears to have gone out of use in Texas by 1730 (Ivey and Fox 1982).

2) Green-on-cream-the rather careless blue/ green decoration on a cream background suggests these sherds are the type Lister and Lister (1982:28) call Mexico City Green-on-cream. That they were found in the fill of the acequia in Unit EII along with a large fragment of a Puebla Polychrome bowl confirms the early dating of this deposit, since this type continued in use into the late seventeenth or early eighteenth centuries (Lister and Lister 1982:28).

3) Blue-on-white-one or two shades of blue in floral designs on a creamy white 


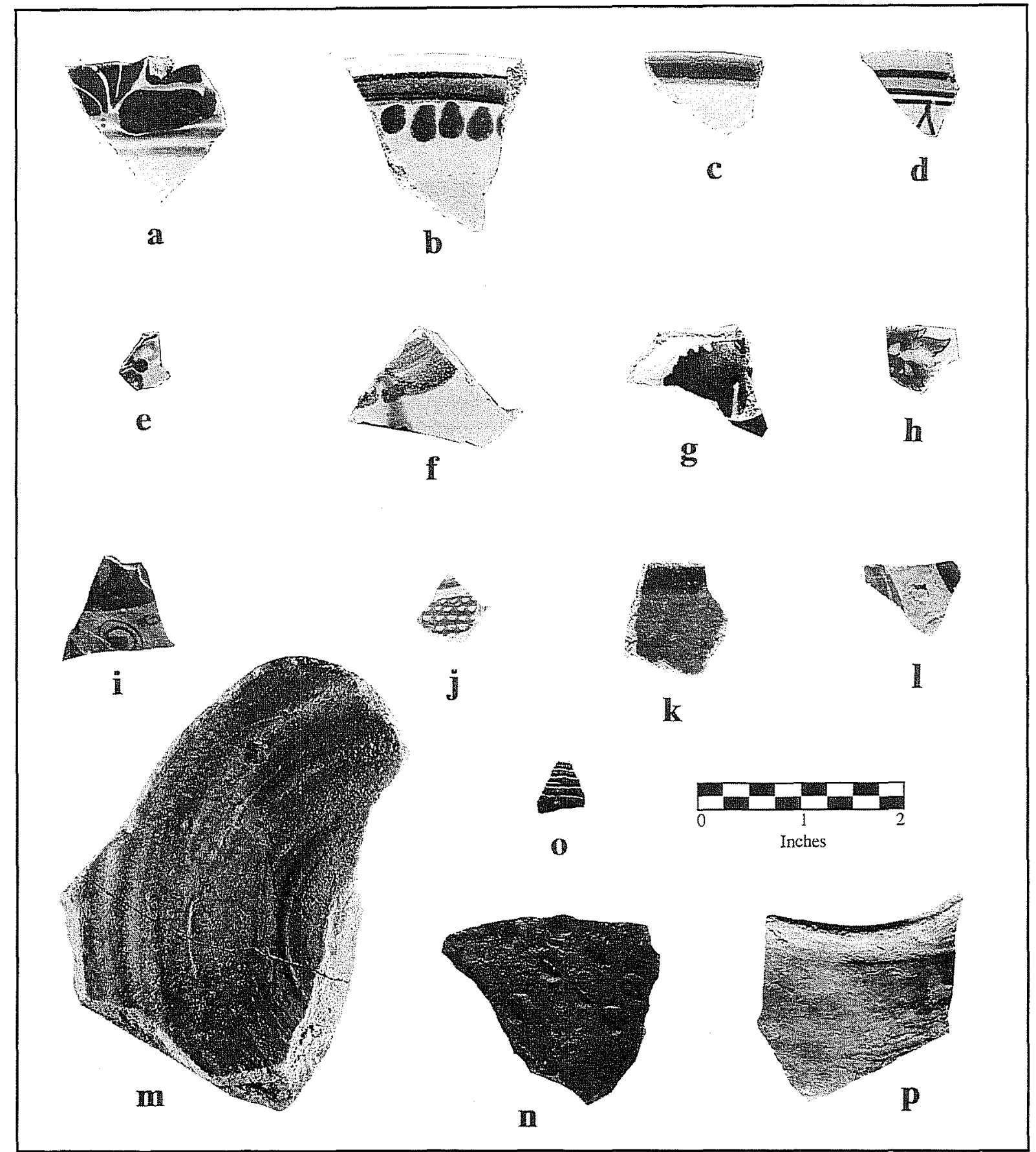

Figure 11. Spanish colonial period ceramics. a-majolica, Puebla Blue-on-white, Unit A, 18-24 inches; b-majolica, San Elizario, Unit C, 27 inches; c-majolica, Huejotzingo, Unit D, 37-43 inches; d-majolica, Aranama Polychrome, Unit B, 21-27 inches; e-majolica, Tumacacori Polychrome, Unit D, 28-31 inches; f-majolica, Guanajuato Polychrome, Unit E, 28 inches; g-majolica, unidentified dark brown-on-white, Unit B, 15-21 inches; h-Oriental porcelain, red and gold overglaze; Unit B, 15-21 inches; i-orange ware, brown underglaze design, Unit A, 18-24 inches; j-orange ware, cream underglaze design, Unit B, 15-21 inches; k-sandy paste ware, green rim on yellow, Unit B, 15-21 inches; 1-Tonalá burnished ware, Unit A, 18-24 inches; m-sandy paste ware, plain yellow, Unit A, 18-24 inches; n-Indian-made, East Texas Type, Unit A, 28-39 inches; o-Indian-made, East Texas Type, Unit D, 31-37 inches; p-Indian-made, Goliad ware, Unit D, 31-37 inches. 
background (Figure 11a). This category probably includes fragments of a number of subtypes and variations of Puebla Blueon-white, San Agustín, and other types as yet unrecognized. The sherds are too small to allow confident separation. Blue-onwhite designs were especially popular throughout the eighteenth century (Lister and Lister 1974:29).

4) San Elizario-a blue band just under the rim is framed by brown lines and the floral designs are accented with dark brown touches (Figure 11b). This type of design was popular in the last half of the eighteenth century (Gerald 1968:44-49).

5) Huejotzingo Blue-on-white-a blue band up to and sometimes slightly over the rim on an otherwise plain white vessel (Figure 11c). This type is also occasionally found with a green or yellow band, or with a scalloped band. It was made throughout the eighteenth and nineteenth centuries (Goggin 1968:195).

6) Aranama Polychrome-includes a number of different floral designs in green, yellow, orange, and blue with dark brown lines (Figure 11d). The distinctive hallmark consists of an orange to yellow band which is framed by brown lines just below the rim. Numerous patterns with this type of color combination were popular during the last half of the eighteenth century (Goggin 1968:198).

7) Tumacacori Polychrome-small floral designs on a light blue background (Figure 11e). This type was popular during the first part of the nineteenth century (Goggin 1968:200).

8) Guanajuato Polychrome-designs in green, rust, and dark brown on a cream background (Figure 11f). The paste is red. This type originated in the early nineteenth century (Seifert 1977:60).
9) Undecorated-plain, creamy white. These are mostly undecorated portions of decorated vessels; however, a number of plain rim sherds indicate the presence of undecorated vessels as well.

10) Miscellaneous Others-sherds of types not previously recorded in San Antonio. One bears a dark brown flower on a creamy white background (Figure 11g). Another has a pale blue line below the rim, beneath which is a portion of a purple floral design.

\section{French Faience}

A few sherds of these ceramics are found in most Spanish deposits of the eighteenth century, two were recovered during this project. One sherd has a pale blue, tin glaze on one side and a dark brown glaze on the other, over a pink paste (Figure 11i); this type of faience originated in Rouen, France, during the late eighteenth century (Noël Hume 1960:560). The other sherd has a yellowish-tan paste, a white tin glaze on both sides, and is undecorated (Figure 11j). Similar sherds have been found in other eighteenth-century mission sites in Texas.

\section{Oriental Porcelain}

Sherds have red and gold floral designs overglaze on a white background (Figure 11h). Similar sherds are found in most Spanish sites in North America.

\section{Discs}

Discs made of sherds or sandstone which vary in diameter from one to four or more inches are usually present in Spanish collections. The purpose of these discs is not confidently known; those of smaller diameters may have been used in games, as suggested by Schuetz (1969:74). 


\section{Metal Artifacts}

\section{Brass and Copper}

Numerous fragments of copper and/or brass were found in the excavations, primarily scraps left when larger pieces were cut (Figure 12a). During the Spanish occupation, scarce copper vessels were repaired and reused as long as possible, then cut up to make or repair other objects.

\section{Buttons}

The recovered buttons were cast of copper alloy in one piece with a hole drilled afterwards in the shank (Figure 12b). This type of button was used in the eighteenth and early nineteenth centuries.

\section{Medallions}

Religious medallions are found on most mission sites. The one recovered in this project (Figure 12e) bears the head of a woman on one side and the head and upper torso of what appears to be a man on the other. The letters which surround the figures are illegible.

\section{Spoon}

A heavy cast copper spoon with pewter plating (Figure 13a) was found in the bottom of the acequia fill, along with the seventeenth- to early eighteenth-century ceramics mentioned above. Such spoons were relatively scarce on the frontier. Mounger (1959:203 and Figure 44) reports one found at Mission Espiritu Santo at Goliad, and Schuetz (1970:Figure 3) illustrates a brass spoon of similar size and proportions which was found at Mission San José during the 1930 s reconstruction. The spoon from the acequia was cast in a mold, but has no maker's mark. The rattail extension of the handle onto the bottom of the bowl of the spoon appears to be typical of seventeenth-century design (Noël
Hume 1976:183). Di Peso (1974: 214) reports a cast copper spoon of similar design found at a Spanish colonial mission near Casas Grandes, Chihuahua, and similar ones have been found on the east coast and in Arizona on seventeenthand eighteenth-century sites.

\section{Military Artifacts}

As might be expected, numerous gun parts and related objects were recovered during the excavations, particularly in Unit D which sectioned the defensive ditch. Represented weapons range from a late eighteenth-century trade gun to muskets in use at the time of the 1836 battle. Identifications were made by Sam Nesmith, military researcher, formerly with the Institute of Texan Cultures.

\section{Gun Parts}

\section{Gunflints}

Eight of the nine whole and partial gunflints recovered were made of local chert. Three representative flints have been chosen for illustration (Figure 14a-c). A large flint made of local material falls within the range suggested by Hamilton (1960:39) for a cannon flint. Another made of local chert is a "gun spall," made from a large flake on which the bulb of percussion is still visible on the reverse side. A third gunflint is made of a dark, opaque material characteristic of English flints (Caldwell 1960:187).

\section{Lead balls}

Lead balls (Figure 14d-f) for use in weapons of the period were found to be of three general sizes: ca. 36 caliber and 51 caliber for use in Kentucky rifles or pistols, and ca. 71 caliber for use in the Brown Bess musket. The Brown Bess was the standard musket used by the Mexican forces in the 1835 to 1836 period. General Cós's army left many of these guns behind in 1835 , so it is likely the Alamo defenders had them to use during the battle of 1836 (Nesmith, personal communication 1980). 


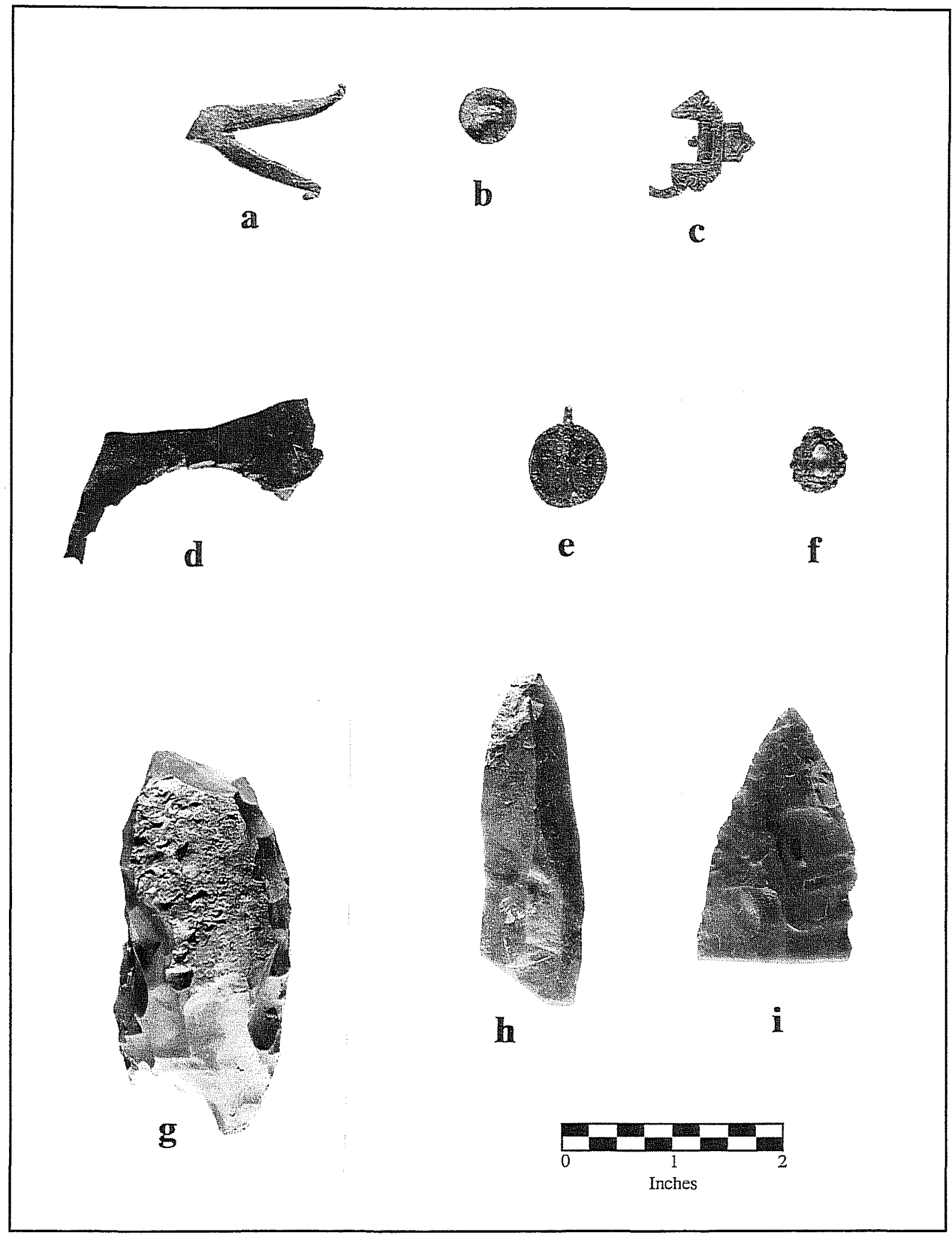

Figure 12. Spanish colonial period artifacts. a-cut copper fragment; b-cast copper/brass button with drilled shank; c-decorative buckle; d-cut brass fragment; e-religious medal; f-trade jewelry fragment, faceted glass set in copper; g-heavy chert tool, unifacially worked; h-large chert blade, edges show evidence of use-alteration; i-broken chert biface. 


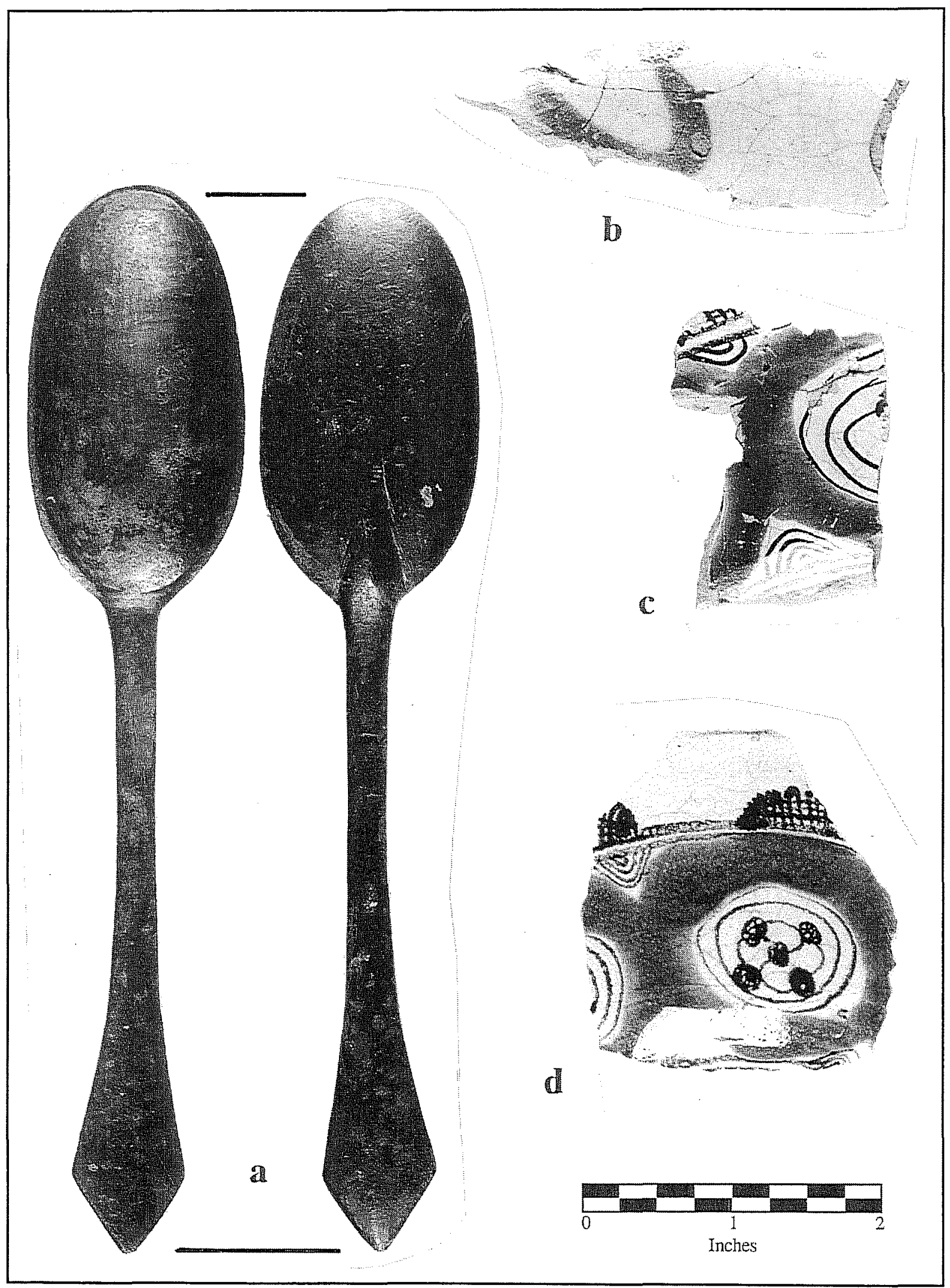

Figure 13. Artifacts from the acequia. a-cast copper spoon with pewter plating; $\mathrm{b}$ - green-on-cream majolica bowl sherd; c-Puebla Polychrome majolica sherd; d-Puebla Polychrome majolica bowl sherd. 


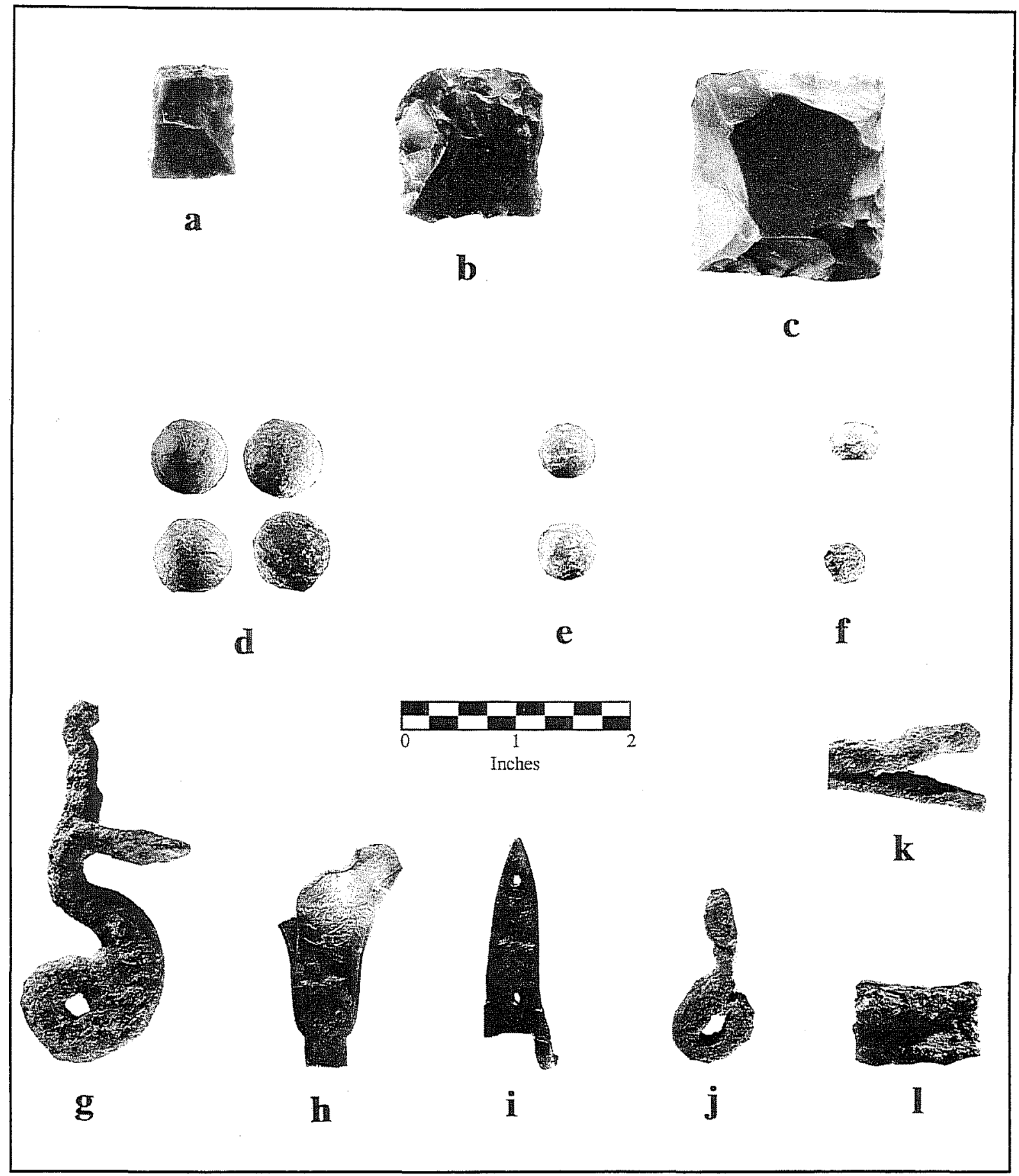

Figure 14. Military artifacts. a-English musket flint, 3/4 x 1 inch, Unit D, 24-31 inches; b-spall musket flint of local material, $13 / 4 \times 1 \frac{11}{16}$ inches, Unit A-3, 12-18 inches; c-cannon-size flint of local material, $17 / 8 \times 1 \frac{11}{16}$ inches, Unit A-3, 18-24 inches; d-balls for Brown Bess musket, 5/8 inches, Unit D-1, 24-18 inches and 31-39 inches, Unit D-2, 24-28 inches, Unit A-4, 18-24 inches; e-balls for Kentucky rifle or pistol, ${ }^{13} / 16$ inches, Unit D, 43-49 inches; f-balls for Kentucky rifle or pistol, ${ }^{11} / 16$ inches, Unit D-2, 31-39 inches, Unit D-3, 25-31 inches; g-cock from Kentucky rifle, 1790-1820, Unit D, 37-43 inches; h-butt plate finial, Unit C, 21-27 inches; i-patch box fragment, Unit B, 15-21 inches; j-charger for powder flask, Unit A, 18-24 inches; k-frizzen spring for flintlock, Unit A, 18-24 inches; 1-ramrod guide, Unit A, 24-30 inches. 
Ramrod guide or rampipe

A ramrod guide (Figure 141) for a large caliber weapon, possibly a Brown Bess musket, was found in Unit A. It is too corroded for exact identification.

Gun cock

The illustrated flint lock cock (Figure 14g) came from a Kentucky rifle. Such guns were made in Lancaster, Pennsylvania, between 1790 and 1820 (Nesmith, personal communication 1980).

Butt plate finial

A small brass fragment (Figure 14h) with engraved design is similar in outline to butt plate finials illustrated by Hamilton (1960:120 and Figure 52) from an Osage Indian site dating from 1790-1815. However, the decorative design of a crane rising from a marsh is unusual in comparison with the more martial engravings of lances, flags, bows, and quivers generally found on such articles (Blaine and Harris 1967:Figure 37; Hamilton 1960:Figure 52).

\section{Related Objects}

\section{Patch box hardware}

Nesmith identified a fragment of engraved brass from Unit B as part of the lid of a patch box (Figure 14i). This was a box carved into the right side of a gun stock and covered with a hinged metal cover. It was used primarily to store greased patches of thin leather or cloth to be wrapped around the lead ball before it was rammed into the barrel of the gun (Peterson 1962:134, 137).

\section{Powder charger}

Nesmith identified an object found in Unit A as a powder charger (Figure 14j). The person using a muzzle-loading gun carried a supply of gun powder in a horn or flask. He often also had a small charger or measure which would hold the correct amount of powder for loading his gun.

\section{The Anglo-American Period}

Artifacts from this period include ceramics, glass, and metal objects and reflect the growing industrialization in the last half of the nineteenth century.

\section{Ceramics}

Before the Civil War, most ceramics were imported into Texas from England. English wares included several types of brightly decorated white earthenwares (Figure 15a-f) and stoneware bottles. After the Civil War, undecorated white "ironstone" or "granite ware," most of which was made in American potteries, was popular (Figure 15).

\section{Glass}

Fragments of window glass and broken bottles were found throughout the Anglo-American deposits. Of particular interest were olive green bottle necks with laid-on rings which bore leadfoil seals with the bottler's impression "G. MUMM \& C.O/G. deBARY" (Figure $15 \mathrm{k}, 1)$. Identical seals were found in the 1966 excavations (Greer 1967:49) in an area which would have been beneath the Hugo and Schmeltzer store. In the recent excavations, these bottles were found only in the yellow sandy intrusion next to the north wall, in Units $\mathrm{A}$ and $\mathrm{B}$. Evidently these were a part of the inventory of the liquors sold by Honore Grenet and/or Hugo and Schmeltzer, perhaps bottles broken in shipping and subsequently discarded.

\section{Metal}

The majority of the metal from the AngloAmerican deposits consists of machine-made cut and wire nails, screws, bolts, nuts, hinges, and other hardware. A souvenir token patented in 1923 (Figure 15i) and an early bottle cap remover came from level 9-15 inches in Unit B, helping to date the fill in that level. A complete 


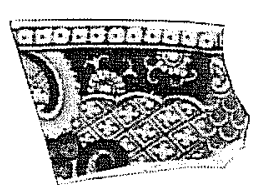

a
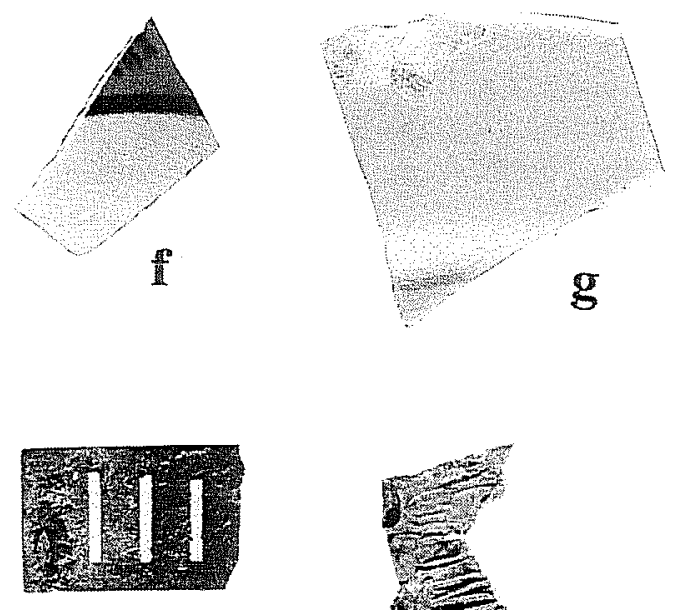

b

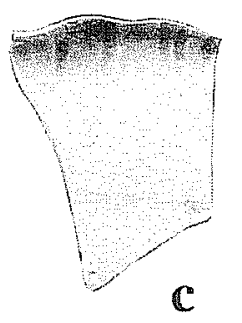

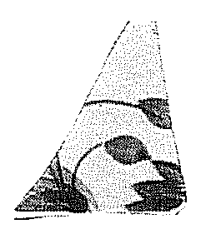

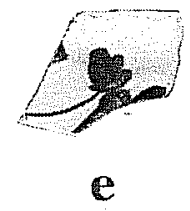

d
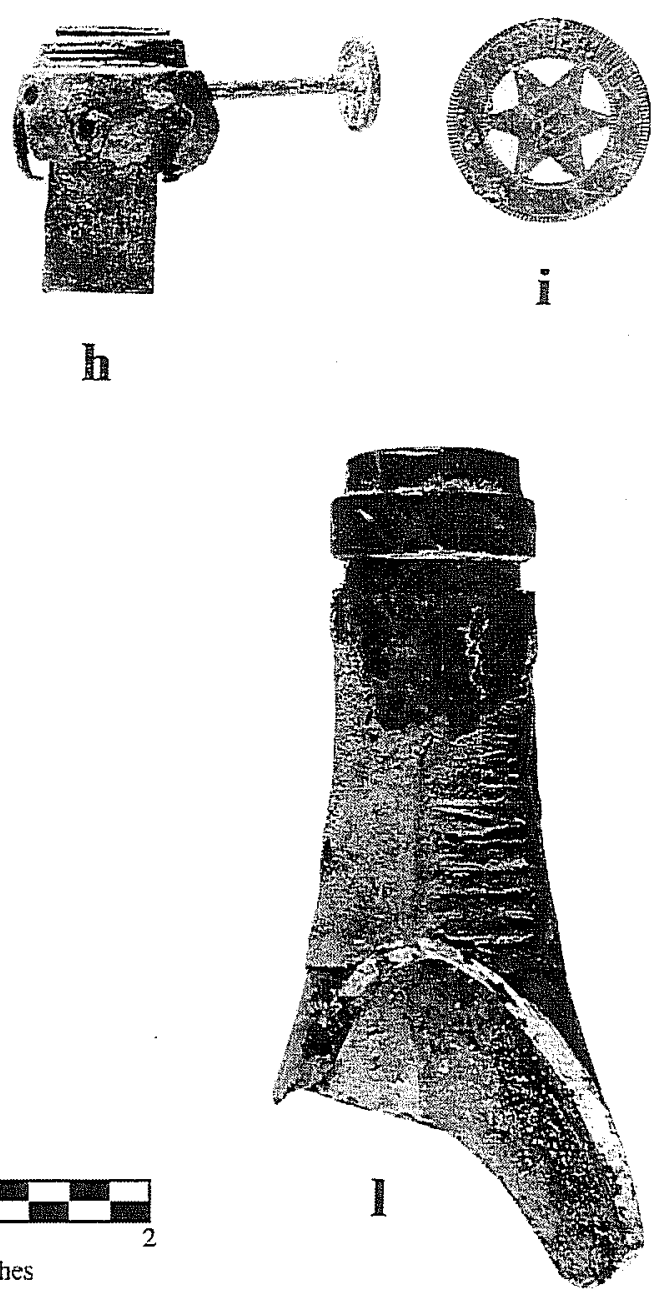

Figure 15. Anglo-American period artifacts. a-whiteware, blue transfer design, Unit B, 12 inches; b-whiteware, brown-on-white annular design, Unit D, 19-25 inches; c-whiteware, green-painted shelledge design, Unit A, 18-24 inches; d-whiteware, green and gold hand-painted design, Unit D; e-whiteware, blue hand-painted design, Unit A, 12-18 inches; f-whiteware, mocha design, Unit A, 12-18 inches; g-ironstone or granite ware, Unit B, 15-21 inches; h-wick adjustment assembly from oil or kerosene lamp, Unit A, 18-24 inches; i-souvenir token, "PAT. 5-15-21/GEO, W. HIENE/CLEVELAND, O.," Unit B, 9-15 inches; j-harmonica reed fragment, Unit A, 12-18 inches; k-lead foil bottle seal, "G. MUMM \& CO./G. deBARY," Unit B, 9-15 inches; 1-olive green bottle neck with part of seal in place, Unit $A$, intrusion. 
wick adjustment assembly for a kerosene or oil lamp (Figure 15h) and a harmonica reed fragment (Figure 15j) were found in the late nineteenth-century deposits in Unit A.

\section{Conclusions}

\section{Mission San Antonio de Valero}

Several of the features found during the excavations may be attributed to the earliest days of the mission on this site. The first such feature is the broad, shallow ditch found in the lowest levels of Units EI and EII. This ditch was filled early in the eighteenth century. It is most easily explained as an acequia, or irrigation ditch, which was apparently lined with a hard, white sandy mortar through some of its length. When this ditch is plotted onto a map of the Valero acequia system, it becomes apparent that this acequia was probably an extension of the Acequia Madre West, and probably ran across the present site of the mission and Alamo Plaza, into the Valero acequia, and on into the San Antonio River at about the crossing of Crockett Street. After an indeterminate period of use, this branch was filled, and a stone and adobe building was built across its trace, at an angle different from both the old acequia line and the general plan of the convento complex.

Because these features were found at the edges of more recent major disturbances, their artifact associations are very poor. We are left to construct a chronology based on nothing more than the very few associated artifacts, their relative stratigraphic positions, and a few historical references. The following interpretation, with the reasoning behind it, is proposed.

In his 1727 visit to Mission San Antonio de Valero, Fray Miguel Sevillano de Paredes indicates the Valero acequia system had been begun in 1723, before the last move of the mission site (de Paredes 1727). He makes it quite clear the acequia was considered the most important single project of the mission, one which took precedence over all other construction jobs. Work on the acequia system had been almost continuous for four years when de Paredes inspected it and found not only the main acequia but also the entire system of laterals and subchannels necessary for it to work effectively.

In 1724 , a year after the acequia was begun, a windstorm destroyed or damaged many of the buildings at the second mission site. Instead of rebuilding on this site, the missionaries took the opportunity to move to a more convenient site. Construction began on the new site and, by 1727, a new Indian village, convento, and church had been built of temporary materials, and work had begun on the permanent convento buildings.

We suggest the main channel of the acequia was completed by 1724 , and the section of acequia found in Unit E and EII was part of this main channel. We further suggest the original line of the main acequia ran diagonally across the area selected as the third site of the mission and, in 1724 , the decision was made to put the Indian village in the area that is now the north end of Alamo Plaza. The acequia was rerouted into a short loop, which ran down through this new village site within the present line of the west wall of the later mission compound. The portion of the original channel which ran through the new mission site was filled, and the temporary missionaries' houses were built in the area north of the present convento complex. These houses were later torn down when the convento was completed and the area north of it was needed for the usual workrooms attached to the convento. This reasoning indicates the stone and adobe structure found in Unit EII was part of the original temporary convento structures built on this third site of the mission. The adobe structure found in the center of the well courtyard in 1966 may have been a shed built in $1724-1727$, or it may have been part of the jacal church used after 1724 . 
This hypothetical sequence would imply, then, that the acequia found in Units E and EII was dug in 1723 and filled in 1724. The adobe and stone building was built in 1724 or so and torn down by about 1745 , when the workshop area is first described in an inventory.

Evidence for other buildings in the area is seen in Unit B, where two strata of broken wall plaster were found, one being deposited directly onto the general occupation debris on the dark brown basal clay surface at 36 inches below the present surface (see Figure 7). Traces of several other buildings remain to be found within the two courtyards of the Alamo, and future work will help to modify or correct the hypothetical sequence proposed. The artifact collection from these levels, albeit limited, is typical of residential structures. The collection shows no strong Indian characteristics; that is, the few artifacts found in these strata are predominantly glazed ceramics. The artifact collection, therefore, does not (yet) contradict our hypothetical dates and usages of this area.

In general, two things are now quite clear: 1) there is a great deal more to the history of the earliest days of Mission San Antonio de Valero than has been written, which comes as no surprise; and 2) a large amount of additional historical research needs to be done. The most important result of this excavation is a painful awareness of how little we know of those first years at the mission. The excavations have revealed a greater need for in-depth research on the records of these years. Until this is accomplished will we be unable to clearly understand the few fragments of buildings we have found.

\section{The Battle of the Alamo}

\section{The Skull and the Straight Trench}

Throughout the majority of the Phase I excavations, we were unable to identify any features as being contemporary with the Battle of the Alamo. Random military hardware was found, but we were unable to specify any particular stratum as dating to ca. 1835-1836. In fact, the dating implies there was no 1835-1836 stratum, but rather a sequence of deposits beginning in the early 1700 s and continuing until about 1800 , at which point the artifact dates generally jump to at least the mid1800 s. The break seemed to occur at the base of the bed of tan clay and cobblestones in Unit D, but in Units A and B the situation was not as clear. Numerous disturbances encountered throughout the Phase I excavations seemed to produce mixed dates. The difficulty was so pronounced that we reached a point where we were uncertain as to just how much of the archaeological record we were seeing was disturbance; the feeling grew that perhaps the great majority was.

The completion of Unit D and the recognition that it was taken up predominantly by the southern portion of some large ditch-like disturbance feature (Figure 5), in which we had found a skull with possible evidence of death by violence, prompted us to cut the additional narrow trench from Unit D to Unit B to obtain a clear view of the cross section of this ditchlike feature. Once this was accomplished, the true nature of the ditch-like disturbance became very obvious.

It was indeed a trench, excavated into the series of apparently undisturbed strata from some higher ground surface, which had since been removed, cutting off the top of the trench and its associated lenses of fill at some unknown distance below their tops. The trench ran parallel to the present line of the 1926 wall along Houston Street and showed distinct signs of having been intentionally refilled with rubble and earth. The surviving depth of the trench was about $2.75 \mathrm{ft}$. The fill consisted of a large quantity of limestone rocks, some over 18 inches long, thrown down onto the smooth floor of the ditch, followed by masses of dark brown clay loam. In the upper portion of this brown loam among the last stones, but still quite clearly within this deposit, the skull was found. 
The trench was located in the area where just such a trench was shown on two different Mexican maps, and where a third Mexican officer described it to be. There could be little doubt we had found the defensive trench dug along the inside of the north courtyard's north wall.

If this conclusion is correct, we know a great deal about this trench. It was dug by the troops under the command of General Cós between October 12 and November 3, 1835, as part of a major attempt to fortify the Alamo before the arrival of the Texan army. The trench stood open through the winter until the Battle of the Alamo, February 23 to March 6, 1836. From March 6 until May 22, the Alamo was in the hands of General Andrade of the Mexican army, who repaired the defenses and undoubtedly cleaned out the debris left in the ditches from the battle. On May 22, upon receiving orders to abandon San Antonio and destroy the defenses of the Alamo, Andrade knocked down the single walls and filled the trenches. While doing this, his troops threw the skull we found into the ditch along with the wall and its associated embankments.

This in itself does not make the skull the remains of a participant in the Battle of the Alamo. It could easily have belonged to someone who was buried in the area at some time in the past, excavated along with the other contents of the defensive trench, heaped against the courtyard wall (see below, "The Defenses of the North Courtyard"), and reinterred when this and the embankments were dumped back into the ditch. The condition of the skull itself, however, argues against this.

The skull (Figure 16) is identified as the cranium of a young individual, probably male, of unknown biological affinity, who died between the ages of 15 and 25 . Four cuts in the skull may have resulted from a knife or saber wound, or may have been of post-depositional origin (Glassman and Steele, Appendix B). Although the facial portion of the skull is gone, the two delicate bones of the bridge of the nose survive. No other skeletal remains were found.

The condition of the cranium argues quite strongly in favor of the following sequence of events. After the death of this individual, his body lay undisturbed for a period of two to four months, until the flesh of the body was largely gone, but the bone was still strong and solid, and the major cartilage structures, such as that of the nose, still survived to some extent. This would have taken at least four months under normal circumstances, but if the weather was warm and humid the time would have been shortened by a month or more. A serious wound on the face of the individual would also shorten the time. We know from Mary Maverick (Green 1952:70) that the spring of 1836 was at least moderately wet.

At this point the body was disturbed, and the skull was mishandled with sufficient force that it disarticulated at what was then its weakest points: where the bones of the face join the bones of the cranium. Several skulls in the CAR collection exhibit this separation, with one important difference. The two small bones of the nose rarely if ever survive such a break. There is only a short period in the sequence of a body's decay when the facial bones will break off but the nasal bones, protected by the remains of the nasal cartilage, will remain with the cranium.

The skull, then, may have belonged to someone who died immediately after being slashed several times by a heavy-bladed weapon a few months before his skull was dumped into a defensive ditch of the Alamo on May 22. From February 23 through March 6, two and a half to three months before that date, a large number of young men of this same age all died violent deaths, many of them the victims of, among other things, heavy-bladed weapons. It would be, we think, an extreme improbability for these two occurrences to have been without connection. As far as we can tell, the skull is that of a participant in the Battle of the Alamo. 




Figure 16. The Alamo skull. Shown approximately three-quarter size.

The identification of the skull as that of a participant, and the ditch as that of part of the defenses of the Battle of the Alamo each depends to some extent on the other. Without the ditch, the case for the skull is much weaker. Without the skull, the case for the ditch is noticeably weaker. The two taken together create a set of closely interlocked relationships. These in turn place very narrow limits on the range of events which would have produced these relationships.
The explanation given here is the simplest and requires the fewest assumptions. The final answer may never be known as fact, and the question of the actual relationship of the skull to the Battle of the Alamo can only be answered at present by probabilities. Other parts of the body of the individual to whom the skull belonged very likely remain in other parts of the straight trench as yet unexcavated. Perhaps the discovery of some of these parts will one day supply more evidence to aid in a definitive answer. 
The skull itself is an item of great interest, but of greater importance to an understanding of the events of the Battle of the Alamo is the recognition of the defensive trench inside the north courtyard. This, taken with the discovery of a defensive ditch outside the south gate by Fox in 1975 (Fox et al. 1976) and the identification of traces of the stockade running from the southwest corner of the church to the east end of the Low Barracks by Eaton (1980), indicates very strongly that the schematic map drawn by $\mathrm{Col}$. Ygnacio Labastida for the Mexican army in 1836 is a faithful representation of the defensive structures built at the Alamo. It is, in fact, the only map which shows all these features (excluding the Sánchez-Navarro map, which is too schematic to be of much use). At the end of Phase I excavations, we had reason to believe that what Labastida recorded was true. If this is the case, Phase II excavations might be made to further evaluate his map. Labastida showed a gun position in the northeast corner of the north courtyard, protected by a circular ditch on the outside of the northeast corner of the walls. Such a circular ditch had never been seriously indicated or described by any modern analysis of the Battle of the Alamo (with the possible exception of Santa Anna's Campaign Against Texas by Richard Santos [1968:164] in which a map of the defenses of the Alamo shows such a ditch; other features of the map are, however, questionable). If Labastida's map proved to be dependable, traces of this gun position or ditch might be found.

\section{The Circular Trench}

During the Phase II excavations in Unit EII, at least two stratigraphically superimposed trenches were encountered (Figure 10). The upper north-south trench had cut across a lower, earlier trench that ran diagonally, but nearly east-west. The upper trench is believed to have been dug during the 1850 Army occupation, while the lower trench was dug and subsequently backfilled earlier, probably remnant of an early acequia completed in 1724 .
In the complicated stratigraphy, a possible third trench is located between the upper and lower trenches. Ivey, who excavated Unit EII, believes the middle trench represents a remnant of a circular trench, exterior to the original compound wall corner, which was part of the fortifications installed before the famous 1836 battle. He suggests, through calculations, that the location of the circular trench lies approximately where it is shown on the Labastida map.

\section{The Defenses of the North Courtyard}

Although we have discovered the positions and some dimensions of the defensive ditches through archaeology, we have few indications of the actual detailed plan of the courtyard at the time of the Battle of the Alamo. In fact, because of the leveling of the courtyard sometime after 1836 , we do not even know what the ground surface level was in 1836, which means we do not know the actual depths of the trenches. The actual depths are needed in order to calculate such things as the heights of the top of the gun positions and the height of the north wall itself. Future excavations may help in estimating these.

Many of the conclusions concerning the present series of excavations make use of rather specialized terms and concepts drawn from field fortification practices in general use in the eighteenth and nineteenth centuries. In order to aid the reader in following our reasoning, a brief outline of these terms and concepts is provided here. All terms are taken from Wheeler (1898), The Elements of Field Fortifications.

The defensive wall of a fortified position was called the parapet. If the top of the parapet was higher than about $4.5 \mathrm{ft}$ above the natural surface of the ground, a small terrace on which the defenders stood was built on the inside of the parapet. This terrace was called the banquette. If possible, the parapet consisted of 
an earth bank supported on its inner face by a revetment, which maintained the earth in the desired position. This revetment could be of timber, stone, brushwood, sandbags, or other easily obtained material.

To supply the earth to build a strong parapet and its associated structures, an excavation was carried out in the immediate area. This excavation was usually incorporated into the defensive plan, and made to obstruct the movements of the enemy or protect the defenders as much as possible. An exterior excavation was called a ditch, while an interior one was call a trench. Military practice based on two centuries of experience had produced a set of proportions of slope and extent called the ordinary profile.

General rules of thumb as to how long it would take to construct earthworks of a given size are frequently quoted in the textbooks. Many of these rules are directly applicable to the defenses of the Alamo.

Gun positions had their own specific terms. A gun firing over the top of a wall from a raised earthen platform was said to be on a barbette. Barbettes were usually placed in the corners of defensive walls; these corners were called salients. A gun firing through a slot in the wall was firing through an embrasure. A gun firing through an embrasure may or may not be on a platform, depending on the height of the wall. If a platform was used, it would not be as high, relative to the wall, as a barbette. Differing tactical considerations determined the choice between the two types of gun position. The barbette gave the gun a wide field of fire, but exposed the gun and its crew to enemy fire, while the embrasure protected the gun and its crew, but limited the field of fire and weakened the parapet.

General rules were accepted for the construction of these gun positions. A barbette was built about $20 \mathrm{ft}$ deep to allow for gun recoil, regardless of the size of the gun, and spaced
$15 \mathrm{ft}$ apart for each gun in the position. A platform for several guns was built in multiples of the 15-x-20-ft unit. Salient barbettes, because of the diagonal position of the platform and the necessity to be able to fire the gun along any of several lines, were built in 5-x-5-ft units for single guns. Barbettes and platformed embrasured batteries had ramps about nine feet wide. The slope of the ramp was such that the length of the ramp was six times its height, so that a platform three feet high required a ramp $18 \mathrm{ft}$ long. The top of the barbette was usually $2.75 \mathrm{ft}$ below the top of the parapet or the mouth of the embrasure, and was covered with a plank surface to prevent the wheels of the gun carriage from cutting ruts into the earthen top of the barbette. Such ruts would prevent the carriage from rolling in recoil, which in turn would force the structure of the carriage itself to absorb the shock of firing. This would quickly smash the carriage and dismount the gun.

These rules were not hard and fast, but were guidelines which evolved from the practices of warfare of the time. Many of the terms used were French, since many of these guidelines were developed in France, and the same terms were frequently transferred virtually unchanged into both English and Spanish. Several of these French terms are used on the Sánchez-Navarro and Labastida maps, such as barbeta, for barbette, and banqueta, for banquette. The basic practices of warfare in 1835 were part of this tradition; that military engineers under General Perfecto de Cós were trained in this tradition and applied their training as best they could to the problem of the fortification of the Alamo is a reasonable assumption.

A short demonstration of the likelihood of this assumption should be included here. We know a gun platform was built in the apse of the Alamo church; through inspection of several drawings made of the walls of the apse in the 1840 s, we can determine that the tops of the walls in this area of the church were virtually those visible on the interior walls of the apse today. This means the guns fired over walls 
whose tops were about $16 \mathrm{ft}$ above the ground. Allowing the standard $2.75 \mathrm{ft}$ as the distance below these walls to the top of the platform gives a platform height of $13.25 \mathrm{ft}$. The church is only about $99 \mathrm{ft}$ in length from the inner face of the apse wall to the inner face of the front wall. Subtracting the standard $20-\mathrm{ft}$ depth for the platform leaves $79 \mathrm{ft}$ as the maximum possible length of the ramp needed to roll the guns up to the platform top. Applying the rule which says a ramp must be at least six times longer than it is high gives a ramp of $79.5 \mathrm{ft}$, which means a ramp of the proper slope would reach ground level at the door of the church. In fact, the wall of the apse was probably intentionally torn down to a height of $16 \mathrm{ft}$ to accomplish this. It appears the rules were indeed being followed during the fortification of the Alamo.

On the Labastida map (Figure 4), the defenses of the north courtyard are described as a foso interior (straight trench) and a bateria á barveta (battery in barbette) with a foso exterior (the circular trench). Sánchez-Navarro adds there was also a banquette along the interior of the wall, and Filisola implies one was present. Since this was the usual practice, we assume one was present.

The straight trench is much too deep to have been intended only as the supply of earth for a banquette along the north wall. The excess had to be used somewhere, and the most likely place is on the outside of the wall for the construction of another standard part of a defensive structure, a parapet of earth to protect the wall from cannon fire.

The straight trench would normally have been placed outside the north wall where it would serve as a greater obstacle to an attacker. The fact that it was placed inside the north wall argues the wall was too low for the effective protection of those defenders not actually on the banquette. Inside the wall, the trench gave an area behind the wall of sufficient depth for troops to maneuver in relative safety.
There is, as yet, no indication of a similar trench on the east line of the original courtyard, and certainly Labastida shows no such trench. The excavations of Mardith Schuetz along this side in 1973 would probably have found such a trench had it been present. The absence of a trench implies the wall may have been considerably higher here, and needed no defense beyond that supplied by the cannon positions in the corner of the courtyard and the top of the church, which also would have protected this wall line. No evidence is yet available to permit us to determine whether freestanding walls were in this area before these defenses were constructed.

\section{Developments after 1836}

\section{The U.S. Army}

The U.S. Army may have been responsible for the wholesale leveling of the courtyard some time after 1836. Certainly little easily recognizable evidence of the army occupation remains, at least in the areas examined during these excavations. The third ditch feature encountered in Units EI and EII was apparently excavated by the army and refilled at a later time, then a wooden structure was built in the area. The army ditch is a good deal more irregular than the underlying circular trench. The available evidence indicates the army ditch was probably straight and ran roughly south along the U.S. Army/Samuel Maverick property line.

The ditch may have been dug about 1847 to aid drainage of the stables built by the army in the courtyard, and filled in about 1851 when an official leasing arrangement was reached with Maverick, giving the army more area south of the line of Houston Street. The footing trench which crossed this filled ditch may have been for the first version of the large wooden building which eventually shows up in Koch's 1873 bird's-eye view of this area. No records are presently available which would provide 
details of when these buildings were constructed or exactly where they were.

\section{The Grenet/Hugo and Schmeltzer Store}

The foundation trench with the cut stone blocks at about $10-\mathrm{ft}$ intervals in the stockade trench and in Units EI and EII was part of the Grenet store's facade along Houston Street. The large foundation trench and its square termination found in Unit A is the end of the wall of the main store building, with a large buttress to help support this wall. The portion of wall foundation in Unit D is the corner of the north gateway with the inner wall of the northern line of warehouses, and the disturbance at its end is probably the position of a large timber which formed the corner framing of the warehouse. Even the cobblestones of the entrance roadway were found.

That we have a very good idea of the disturbances produced by the construction of Grenet's store is readily apparent. Thus it should be possible in future excavations to anticipate these and to recognize them as they are found.

\section{Summary and Recommendations}

The Phase I and Phase II excavations at the north wall have clarified certain aspects of the history of the mission and provided insight into the Battle of the Alamo and the defenses of the north courtyard. From the earliest period of the mission, excavations in Units $\mathrm{E}$ and $\mathrm{EII}$ encountered sections of an acequia, presumably associated with Acequia Madre West, and part of the temporary convento built around 1724 . These discoveries indicate that this section of the Alamo contains important archaeological deposits dating to the poorly understood first years of the mission.
The discovery of the in-filled defensive trench paralleling the 1926 wall corroborates Mexican maps of the north courtyard. The available data suggest that this trench was filled two months after the end of the Battle of the Alamo. It is likely that, in addition to the human skull discussed earlier and in Appendix B, there are other human remains or artifacts from the battle used as fill in this trench.

The excavations also confirmed that the North Courtyard's 1836 surface had been disturbed or leveled sometime after the Battle of the Alamo, presumably by the U.S. Army. Features apparently associated with the army's occupation include the third ditch, dug ca. 1847, encountered in Units E and EII and the footing trench which crossed this ditch after it was filled in ca. 1851 .

The most important conclusion drawn from this project is that the north courtyard and north wall areas of the Alamo contain intact archaeological deposits dating to the early occupation of the mission, the 1836 Battle of the Alamo, and the subsequent U.S. Army occupation of the mission. Any future modifications to the area that involve subsurface disturbance should require archaeological testing. 


\section{References Cited}

Ables, L. R.

1967 The Second Battle for the Alamo. Southwestern Historical Quarterly LXX (3):372-413.

Blaine, J. D., and R. K. Harris

1967 Guns in the Gilbert Site. Bulletin of the Texas Archeological Society 37:33-86.

Caldwell, W. W.

1960 Firearms and Related Materials from Ft. Pierre II (39ST217) Oahe Reservoir, South Dakota. In Indian Trade Guns, complied and arranged by T. M. Hamilton, The Missouri Archaeologist 22:182-191.

Chabot, F. C.

1937 With the Makers of San Antonio. Artes Gráficas, San Antonio.

Colquitt, O. B.

1913 Message of Governor O. B. Colquitt to the Thirty-third Legislature Relating to the Alamo Property. Van Boeckmann-Jones, Austin.

de la Peña, J. E.

1975[1836] With Santa Anna in Texas, A Personal Narrative of the Revolution. Translated and edited by C. Perry. Texas A\&M University Press, College Station.

de Paredes, M. S.

1727 Vista de las Misiones del Rio Grande del Norte por Fray Miguel Sevillano de Paredes en 15 Octobre. Archivo General de Mexico: Historia, Volume 29. Eugene C. Barker Texas History Collection, The University of Texas at Austin.

Di Peso, C. C.

1974 Casas Grandes, A Fallen Trading Center of the Gran Chichimeca. Vol. 3. The Amerind Foundation, Dragoon.

Eaton, J. D.

1980 Excavation at the Alamo Shrine (Mission San Antonio de Valero). Special Report, No. 10. Center for Archaeological Research, The University of Texas at San Antonio.

Filisola, V.

1965[1836] Evacuation of Texas. Translated by J. M. Day. Texian, Waco.

Fox, A. A.

1974 Lead Glazed Wares. In Mission Rosario, Archeological Investigation in 1973, edited by K. Gilmore. Archaeological Report 14, Part I. Texas Parks and Wildlife Department, Parks Division, Historic Sites and Restoration Branch, Austin. 
Fox, A. A., F. A. Bass, Jr., and T. R. Hester

1976 The Archaeology and History of Alamo Plaza. Archaeological Survey Report, No. 16. Center for Archaeological Research, The University of Texas at San Antonio.

Gerald, R. E.

1968 Spanish Presidios of the Late Eighteenth Century in Northern New Spain. Museum of New Mexico Research Records No. 7. Museum of New Mexico Press, Santa Fe.

Goggin, J. M.

1968 Spanish Majolica in the New World, Types of the Sixteenth to Eighteenth Centuries. Yale Publications in Anthropology 72. Department of Anthropology, Yale University, New Haven.

Green, R. M.

1952 Samuel Maverick, Texas: 1803-1870. Privately printed, San Antonio.

Greer, J. W.

1967 A Description of the Stratigraphy, Features and Artifacts from an Archaeological Excavation at the Alamo. Report 3, State Building Commission Archaeological Program, Austin.

Habig, M.A.

1968 The Alamo Chain of Missions, A History of San Antonio's Five Old Missions. Franciscan Herald, Chicago.

1977 The Alamo Mission, San Antonio de Valero, 1718-1793. Franciscan Herald, Chicago.

Hamilton, T. M.

1960 Some Gun Parts from 18th Century Osage Sites. The Missouri Archaeologist 22:120-149.

Heusinger, E. W.

1951 A Chronology of Events in San Antonio. Standard Printing, San Antonio.

Huson, H., editor

1949 Dr. J. H. Barnard's Journal. Goliad Bicentennial Edition. Privately published.

Ivey, J. E., and A. A. Fox

1982 Archaeological Investigations at Mission Concepción and Mission Parkway. Archaeological Survey Report, No. 114. Center for Archaeological Research, The University of Texas at San Antonio.

Lister, F. C., and R. H. Lister

1974 Maiolica in Colonial Spanish America. Historical Archaeology VIII:17-52.

1982 Sixteenth Century Maiolica Pottery in the Valley of Mexico. The University of Arizona Press, Tucson.

Lord, W.

1961 A Time to Stand. Harper, New York. 
Mounger, M. A.

1959 Mission Espíritu Santo of Coastal Texas: An Example of Historic Site Archeology. Master's thesis, The University of Texas, Austin.

Nixon, P. I.

1936 A Century of Medicine in San Antonio. Privately published, San Antonio.

Noël Hume, I.

1960 Rouen Faïence in Eighteenth-Century America. Antiques LXXVIII(6):559-561.

1970 A Guide to Artifacts of Colonial America. Knopf, New York.

Ortiz, F. F. X.

1745 Razón de la Visita a las Misiones de la Provincia de Texas. Vol. I. Edited by V. Rea, Mexico. Microfilm. Bexar Archives, Barker Texas History Center, University of Texas, Austin.

Peterson, H. L.

1962 The Treasury of the Gun. Golden, New York.

San Antonio Express [SAE] [San Antonio, Texas]

1912 [article] 3 March.

1913 [article] 1 July 1:18.

1926 [article] 8 December: 18.

1926 [article] 19 December:18.

Santos, R.

1968 Santa Anna's Campaign Against Texas, 1835-1836. Texian, Waco.

Schoelwer, S. P.

1985 Alamo Images: Changing Perceptions of a Texas Experience. DeGolyer Library and Southern Methodist University Press, Dallas.

Schuetz, M. K.

1969 Description of the Artifacts and Ethno-History of the Coahuiltecan Indians. The History and Archaeology of Mission San Juan Capistrano, San Antonio, Texas, Volume II. Report 11, State Building Commission Archeological Program, Austin.

1970 Excavation of a Section of the Acequia Madre in Bexar County, Texas, and Archaeological Investigations at Mission San José in April, 1968. Archaeological Report 19, Texas Historical Survey Committee, Austin.

1973 Archeological Investigations at Mission San Antonio de Valero, The Second Patio. Unpublished manuscript on file, Office of the State Archeologist, Texas Historical Commission, Austin.

Seifert, D. J.

1977 Archaeological Majolicas of the Rural Teotihuacan Valley, Mexico. Ph.D. dissertation, The University of Iowa, Iowa City. 
Snow, D. H.

1965 The Chronological Position of Mexican Majolica in the Southwest. El Palacio 72 (1):25-35.

Steinfeldt, C.

1978 San Antonio Was: Seen Through a Magic Lantern, Views from the Slide Collection of Albert Steves, Sr., San Antonio Museum Association, San Antonio.

Suhm, D. A., and E. B. Jelks

1962 Handbook of Texas Archeology: Type Descriptions. Special Publication 1, Texas Archeological Society and Texas Memorial Museum, Austin.

Tunnell, C. D.

1966 A Description of Enameled Earthenware from an Archeological Excavation at Mission San Antonio de Valero (The Alamo). State Building Commission Archeological Report Program 2, Austin.

Webb, W. P., editor

1952 The Handbook of Texas. Two volumes. The Texas State Historical Association, Austin.

Wheeler, J. B.

1898 The Elements of Fortification for the Use of the Cadets of the United States Military Academy at West Point, N.Y. D. Van Nostrand, New York.

Young, K. R.

ca. 1970s Notes and Related Correspondence Covering the United States Army Quartermasters' Occupation of the Alamo, 1846-1854. Unpublished manuscript on file, Center for Archaeological Research, The University of Texas at San Antonio. 


\title{
Appendix A: Faunal Analysis for the Alamo North Wall Excavations
}

\author{
Robert F. Scott IV
}

\section{Introduction}

Phase I and II excavations at the Alamo North Wall Project yielded a large, varied, and wellpreserved collection of faunal material. The two phases of work recovered over 1,000 bones which provide a glimpse of the eighteenth- and nineteenth-century methods of securing meat and animal by-products. Domestic and wild animals are included in the analyzed bones. Butchering marks are prominent on over 100 bones from Phase I and 97 bones from Phase II, providing an opportunity to reconstruct the sequence and tools used to dismember the animals. The Alamo collection, in general, provides a unique situation in which to study historic subsistence.

The following analysis proceeds in two parts, dealing first with Phase I remains, then with those from Phase II. The collection is then analyzed as a whole, comparing and contrasting the two phases. Bones were analyzed utilizing a private comparative collection and the comparative faunal collection at the Texas Archeological Research Laboratory, The University of Texas at Austin. Two priorities were pursued during the analysis: identify the types and numbers of animals utilized for food, and define a detailed butchering sequence. Each bone was examined for butchering marks and evidence of burning, carnivore gnawing, age, and fractures.

\section{Phase I}

During Phase I, five units (A-E) were excavated. Eight hundred eighty-four bones were recovered, the majority of which were identifiable to some extent (Tables A-1, A-2, and $A-3$ ). Of the five units, A, B, and D contained the majority of the remains, with A yielding the greatest number $(n=367)$.

\section{Unit A}

Unit A was a 4-x-10-ft trench crossing the back wall of what had been the Grenet/Hugo and Schmeltzer store. The excavation extended to a depth of 56 inches and recovered 367 bones. This number represents 42 percent of the entire bone recovery for Phase I. Bones were recovered throughout the unit but were particularly concentrated from 12-36 inches deep. Recovery was greatest in A-1-4 (24-30 inches), accounting for about one-third $(n=120)$ of the bones found in Unit A.

In terms of species recovered, the unit showed very little variation from the upper levels through the lower ones. Generally, the greatest numbers of bones were associated with the largest numbers of artifacts. The middle levels (18-24 inches and 24-30 inches) contained the majority of the bones distributed among the greatest number of animal genera. A-1-4 (24-30 inches) contained at least one example of every animal identified from Unit A with the exception of an antelope identified in A-4 (18-24 inches).

As in the other units, A contained butchered and discarded remains. Whole bones are usually only associated with rodent and fish remains, and the lower leg bones of the larger animals. In particular, remains from A-1-4 (24-30 inches) are composed of the discarded axial elements of skeletons (vertebra, pelvis, and sacrum) and the fragmentary ends of long bones also discarded during dismemberment. Almost 20 percent of the bones $(n=23)$ in $A-1-4$ (24-30 inches) show evidence of having been 
Table A-1. Phase I, Bone Recovery

\begin{tabular}{|c|c|c|c|c|}
\hline \multicolumn{2}{|l|}{ Provenience } & \multirow{2}{*}{$\begin{array}{l}\text { Number } \\
\text { Identified }\end{array}$} & \multirow{2}{*}{$\begin{array}{c}\text { Not } \\
\text { Identified }\end{array}$} & \multirow[b]{2}{*}{ Butchered } \\
\hline Unit & $\begin{array}{l}\text { Depth } \\
\text { in inches }\end{array}$ & & & \\
\hline A Interior of store & & 7 & & 1 \\
\hline A West & $39-42$ & 9 & 1 & 1 \\
\hline $\mathrm{A}-1$ & $0-6$ & 1 & & \\
\hline $\mathrm{A}-1$ & $6-12$ & 1 & & \\
\hline $\mathrm{A}-1$ & $12-18$ & 6 & 1 & 3 \\
\hline $\mathrm{A}-1$ & $18-24$ & 2 & 1 & \\
\hline $\mathrm{A}-2$ & $42-45$ & 2 & & \\
\hline $\mathrm{A}-2$ & $18-24$ & 15 & 2 & 4 \\
\hline $\mathrm{A}-3$ & $12-18$ & 17 & 1 & 4 \\
\hline$A-3$ & $18-24$ & 52 & 19 & 5 \\
\hline$A-3$ & $18-24$ & 5 & & \\
\hline$A-4$ & $12-14$ & 2 & & 1 \\
\hline$A-4$ & $14-18$ & 7 & 1 & 2 \\
\hline$A-4$ & $18-24$ & 34 & 22 & 6 \\
\hline A-1-4 & $24-30$ & 110 & 10 & 23 \\
\hline A-1-4 & $30-33$ & 13 & 1 & 1 \\
\hline A-1-4 & $33-36$ & 17 & & 1 \\
\hline A-1-4 & $36-39$ & 8 & & \\
\hline Total Unit A & & 308 & 59 & 52 \\
\hline $\mathrm{B}$ & $53-59$ & & 1 & \\
\hline B-1 & $0-3$ & 4 & & 2 \\
\hline B-1 & $3-9$ & 4 & & \\
\hline $\mathrm{B}-1$ & $9-15$ & 2 & 1 & \\
\hline B-1 & $15-21$ & 15 & 6 & 5 \\
\hline B-1 & $21-27$ & 7 & 2 & \\
\hline B-1 & $25-28$ & 5 & 1 & \\
\hline B-1 & $27-33$ & 1 & & 1 \\
\hline B-1 & $27-39$ & 7 & 3 & 1 \\
\hline B-2 & $3-9$ & 1 & 1 & 1 \\
\hline B-2 & $15-21$ & 5 & 3 & \\
\hline B-2 & $21-27$ & 6 & 3 & 2 \\
\hline B-2 & $27-39$ & 10 & 3 & \\
\hline B-3 & $9-15$ & 12 & 3 & 1 \\
\hline $\mathrm{B}-3$ & $15-21$ & 29 & 12 & 3 \\
\hline $\mathrm{B}-3$ & $21-27$ & 12 & 1 & 1 \\
\hline B-3 & $27-30$ & 2 & & \\
\hline B-3 & $30-33$ & 7 & 1 & 2 \\
\hline B-3 & $33-36$ & 10 & & 2 \\
\hline B-3 & $36-39$ & 8 & 2 & \\
\hline $\mathrm{B}-4$ & $12-15$ & 8 & 5 & \\
\hline
\end{tabular}


Table A-1. continued

\begin{tabular}{|c|c|c|c|c|}
\hline \multicolumn{2}{|l|}{ Provenience } & \multirow[b]{2}{*}{$\begin{array}{l}\text { Number } \\
\text { Identified }\end{array}$} & \multirow{2}{*}{$\begin{array}{c}\text { Not } \\
\text { Identified }\end{array}$} & \multirow[b]{2}{*}{ Butchered } \\
\hline Unit & $\begin{array}{c}\text { Depth } \\
\text { in inches }\end{array}$ & & & \\
\hline B-4 & $15-18$ & 2 & & 2 \\
\hline B-4 & $18-28$ & 16 & & 5 \\
\hline$\overline{B-4}$ & $28-30$ & 1 & & \\
\hline B-4 & $29-35$ & 3 & 2 & \\
\hline Total Unit B & & 177 & $\mathbf{5 0}$ & 28 \\
\hline$C-1$ & $9-15$ & 1 & 1 & \\
\hline $\mathrm{C}-1$ & $15-21$ & 3 & & \\
\hline $\mathrm{C}-1$ & $21-27$ & 14 & 2 & 4 \\
\hline $\mathrm{C}-1$ & $27+$ & 11 & 8 & 6 \\
\hline Total Unit C & & 29 & 11 & 10 \\
\hline D & $31-37$ & 9 & 2 & 2 \\
\hline $\bar{D}$ & $37-43$ & 18 & 7 & 3 \\
\hline $\bar{D}$ & $43-49$ & 33 & 12 & 3 \\
\hline $\bar{D}$ & $49-57$ & 13 & 5 & 3 \\
\hline$\overline{D-1}$ & $15.5-17$ & 1 & 1 & \\
\hline$\overline{\mathrm{D}-1}$ & $17-24$ & 5 & & \\
\hline D-1 & $24-28$ & 1 & & \\
\hline D-1 & $28-31$ & 2 & 2 & \\
\hline D-1 & $31-37$ & 9 & 2 & 4 \\
\hline $\mathrm{D}-1$ & $37-43$ & 9 & 1 & 1 \\
\hline $\mathrm{D}-2$ & $17-24$ & & 6 & \\
\hline D-3 & $12.5-14$ & 1 & & \\
\hline D-3 & $14-19$ & 1 & 2 & \\
\hline $\mathrm{D}-3$ & $19-25$ & 9 & 2 & 2 \\
\hline D-3 & $25-31$ & 6 & & 1 \\
\hline$\overline{D-3}$ & $31-33$ & 4 & 1 & \\
\hline$\overline{\mathrm{D}-1}$ & $24-28$ & 4 & 2 & 2 \\
\hline$\overline{\mathrm{D}-2}$ & $37-43$ & 6 & 4 & 2 \\
\hline Total Unit D & & 131 & 49 & 23 \\
\hline $\mathrm{E}$ & $36-42$ & 2 & 1 & \\
\hline $\bar{E}$ & $48-54$ & 4 & 2 & \\
\hline Top of wall & & 3 & & 2 \\
\hline$\overline{E-1}$ & $18-24$ & 5 & & 1 \\
\hline East of wall & 28 & 5 & & 1 \\
\hline West of wall & $28+$ & 4 & & \\
\hline E-1 & $33-36$ & 3 & 3 & \\
\hline Wall & $34-38$ & 3 & 4 & 1 \\
\hline E-1 & $39-41$ & 1 & & \\
\hline Total Unit E & & 36 & 10 & 6 \\
\hline
\end{tabular}


Table A-2. Phase I, Faunal Identification and Occurrence

\begin{tabular}{|c|c|c|c|c|c|c|c|}
\hline Taxonomic Name & Common Name & $\mathbf{A}$ & $\mathbf{B}$ & $\mathrm{C}$ & D & $\mathbf{E}$ & Domesti \\
\hline \multicolumn{8}{|l|}{ FISH } \\
\hline Ictalurus punctatus & Channel catfish & $\mathrm{x}$ & $\mathrm{x}$ & & $\mathrm{x}$ & $\mathrm{x}$ & \\
\hline$?$ & Unidentified fish & $\mathrm{x}$ & & & $\mathrm{x}$ & & \\
\hline \multicolumn{8}{|l|}{ REPTILE } \\
\hline$?$ & Unidentified turtle & & $\mathrm{x}$ & & & & \\
\hline \multicolumn{8}{|l|}{ BIRD } \\
\hline Tetraonidae & Grouse family & & $\mathrm{x}$ & & & & \\
\hline Colinus virginianus & Bobwhite quail & & & & $\mathrm{x}$ & & \\
\hline Gallus gallus & Chicken & $\mathrm{x}$ & $\mathrm{x}$ & $\mathrm{x}$ & $\mathrm{x}$ & $\mathrm{x}$ & $\mathrm{x}$ \\
\hline Meleagris gallopavo & Turkey & $\mathrm{x}$ & $\mathrm{x}$ & $\mathrm{x}$ & & & $\mathrm{x}$ \\
\hline$?$ & Unidentified bird & $\mathrm{x}$ & $\mathrm{x}$ & $\mathrm{x}$ & $\mathrm{x}$ & $\mathrm{x}$ & \\
\hline \multicolumn{8}{|l|}{ MAMMAL } \\
\hline Dasypus novemcinctus & Armadillo & & & & $\mathrm{x}$ & & \\
\hline Felis cf. domesticus & Domestic cat & $\mathrm{x}$ & & & & & $\mathrm{x}$ \\
\hline Procyon lotor & Raccoon & $\mathrm{x}$ & & & & & \\
\hline Canis familiaris & Domestic dog & $\mathrm{x}$ & $\mathrm{x}$ & $\mathrm{x}$ & & & $\mathrm{x}$ \\
\hline Canidae & Unidentified canid & $\mathrm{x}$ & $\mathrm{x}$ & & $\mathrm{x}$ & & \\
\hline Sylvilagus sp. & Cottontail & $\mathrm{x}$ & & & & & \\
\hline Sigmodon hispidus & Cotton rat & & $\mathrm{x}$ & & & & \\
\hline Rattus rattus & Roof rat & $\mathrm{x}$ & & & & $\mathrm{x}$ & \\
\hline Neotoma sp. & Wood rat & $\mathrm{x}$ & & & & & \\
\hline$?$ & Unidentified rodent & $\mathrm{x}$ & & & $\mathrm{x}$ & $\mathrm{x}$ & \\
\hline Sciurus niger & Fox squirrel & & & & & $\mathrm{x}$ & \\
\hline Odocoileus virginianus & White-tailed deer & $\mathrm{x}$ & $\mathrm{x}$ & $\mathrm{x}$ & $\mathrm{x}$ & & \\
\hline Antilocapra americana & Antelope & $\mathrm{x}$ & & & & & \\
\hline Sus scrofa & Pig & $\mathrm{x}$ & $\mathrm{x}$ & $\mathrm{x}$ & $\mathrm{x}$ & & $\mathrm{x}$ \\
\hline Capra hirca & Goat & $\mathrm{x}$ & $\mathrm{x}$ & $\mathrm{x}$ & $\mathrm{x}$ & $\mathrm{x}$ & $\mathrm{x}$ \\
\hline Bos sp. & Cow & $\mathrm{x}$ & $\mathrm{x}$ & & $\mathrm{x}$ & $\mathrm{x}$ & $\mathrm{x}$ \\
\hline Equus sp. & Horse & $\mathrm{x}$ & & & $\mathrm{x}$ & & $\mathrm{x}$ \\
\hline
\end{tabular}


Table A-3. Phase I, Butcher-marked Skeletal Elements by Unit

\begin{tabular}{lccccc}
\hline & A & B & C & D & E \\
\hline Vertebrae & 23 & 7 & 3 & 7 & 1 \\
Pelvis & 3 & 0 & 0 & 4 & 0 \\
Long bones & 11 & 6 & 6 & 5 & 1 \\
Ribs & 11 & 6 & 1 & 0 & 2 \\
Scapulae & 2 & 2 & 0 & 5 & 0 \\
Skull + mandible & 0 & 1 & 0 & 0 & 0 \\
Fragments & 2 & 6 & 0 & 2 & 2 \\
\hline & $\mathbf{5 2}$ & $\mathbf{2 8}$ & $\mathbf{1 0}$ & $\mathbf{2 3}$ & $\mathbf{6}$ \\
\hline \hline
\end{tabular}

butchered. This percentage is greater than the 17 percent of bones in Unit $A$ as a whole exhibiting butchering evidence and 13 percent of the entire Phase I collection. Vertebrae are the most commonly butcher-marked bone in A1-4 (24-30 inches) and one of the most commonly marked in Unit A.

In Unit $\mathrm{A}$ as a whole, remains of eight genera of domesticated animals were found. With one exception, they can all be considered food sources. A single house cat tooth found in A-1-4 (24-30 inches) definitely represents a domestic animal, but not necessarily one prized for its palatability. The tooth, an immature one, could well have been lost during scavenging. A single horse and possibly three cows were present in A-1-4 (24-30 inches), as were at least one goat, one pig, and one dog. Several chickens and a turkey complete the list. (Note: the fragmentary nature of the collection makes estimation of a minimum number of each animal tenuous. Numbers given represent the level stated only and not Unit A as a whole.)

Among the wild animals identified, catfish were found throughout Unit A. Cottontail rabbits, white-tailed deer, and a single antelope were identified, in addition to a single raccoon bone occurring in A-1-4 (24-30 inches). The remains of two rodents were also recorded. One, a wood rat (Neotoma sp.) is native to the area; the second, however, appears to be a common roof rat (Rattus rattus), a European introduction to the New World.

From Unit A, six bones exhibit puncturing or beveling and "feathering," indicating gnawing by carnivores such as dogs. Seven bone fragments are discolored from burning. Long bone shafts and fragments of long bones are notably absent from the Unit A collection.

\section{Unit B}

Unit B was located $15 \mathrm{ft}$ east of Unit A on the south side of the wall and encompassing the stockade trench. Its original dimensions were $4 \times 10 \mathrm{ft}$, reaching a depth of 39 inches. Bone recovery from this unit represents 26 percent $(n=227)$ of the total Phase I recovery. Twelve percent $(n=28)$ of the bone in Unit B exhibited some butcher marks. Faunal recovery was greatest in B-3 (15-21 inches), B-1 (15-21 inches), and B-4 (18-28 inches), although remains were found throughout the unit. No particular level dominated recovery as did the 24-30 inch level in Unit A.

With a few minor exceptions, Unit B resembles the other four units in Phase I. Domestic animals dominate the collection, with four wild animals and a single rodent rounding out the 
identified bones. All the domestic animals seen in Unit A also occur in B, with the exception of the cat. Goats are most frequent, with cows and pigs next in order. Dog remains are slightly more common in B than any other Phase I unit. Catfish bones occur throughout the levels. As in Unit A, the remains exhibit little difference stratigraphically. Three animals occur in this unit and not elsewhere in Phase I. A single cotton rat (Sigmodon hispidus)-a common rodent throughout Texas even today-was identified from B-3 (30-33 inches). B-3 (15-19 inches) produced a single bird bone assignable to the grouse family (Tetraonidae). This family includes grouse, prairie chicken, and ptarmigans, though the prairie chicken (Tympanuchus) is a logical candidate to assign to the bone. The only fragment of turtle shell recovered from Phase I, in level B-3 (36-39 inches), was not identifiable to any level more specific than "turtle."

Only two fragments of burned bone and a single carnivore-gnawed bone (a goat metacarpal) were found in the Unit B collection. Excluding teeth fragments, this unit also contained the only mandible fragment identified in the Phase I collection: a saw-cut mandibular condyle from a goat-size animal. Vertebrae are the most commonly butcher-marked bones $(n=7)$ though marked ribs are almost as numerous $(n=6)$.

\section{Unit C}

Unit $C$ was located between Units $A$ and $B$, five feet east of Unit A. The unit was excavated to a depth of over 27 inches and found to be composed of primarily disturbed fill. Bones recovered in Unit $\mathrm{C}$ were from the unscreened fill.

The majority of bones in this unit were recovered in levels 21-27 inches and 27 inches plus. Only four percent of the total bones in Phase I $(n=40)$ were in the unit. Of these, 28 percent $(n=11)$ are butchered marked, a high percentage no doubt skewed by the method of recovery. Five domestic animals-pig, goat, chicken, dog and turkey-were identified, along with fragments of a white-tailed deer and an unidentified bird. The assemblage includes several butchered vertebrae and long bone fragments. Two burned fragments and a single carnivore-gnawed bone are also included in the Unit C collection.

\section{Unit D}

Unit D was a 6-x-6-ft square located south of Unit B in the area of an 1878 wall. It was excavated to a depth of 57 inches and included excavations in the pipe trench and a posthole. In total, 180 bones were recovered, 20 percent of the total Phase I recovery. Of this number, 13 percent $(n=23)$ are butcher marked.

Unit $\mathrm{D}$ bone recovery was greatest in level 43-49 inches, but concentrated between levels 31-37 inches, 37-43 inches, and 43-49 inches. As in units $A, B$, and $C$, cow, pig, goat, chicken, and dog remains were recorded. A single tooth represents a horse in this unit (49-57 inches), the only one recorded outside of Unit A in Phase I or II excavations. Unit D produced the sole armadillo recovered and the remains of a single quail. In total, four game animals, six domestic species, and one unidentified rodent were recorded from the unit.

Distribution of the remains stratigraphically resembles Units A and B, as little difference in the type of animals represented is seen between the deeper and shallower levels. Also as in A and $B$, the collection is primarily the discarded axial and articular portions of the skeleton. Vertebrae are also the most commonly butchered element encountered. One major difference between $\mathrm{D}$ and the other four units is the number of butchered scapula and pelvis elements. Five of the former and four of the latter elements were identified, all but one representing a goat or goat-size animal. One scapula fragment represents a cow. The total of nine recovered in Unit $D$ is greater than the combined total of butchered pelvis and scapulae from Units A, B, C, and E. 


\section{Unit E}

Excavation Unit $\mathrm{E}$ was a 5-x-5-ft square situated east of Unit B along the south edge of the north wall. It was placed to include a possible extension of the convento's east wall. Faunal recovery in $E$ only accounts for six percent $(n=46)$ of the Phase I total. Of that number, 13 percent $(n=6)$ shows evidence of butchering. The material was spread through every level and, as in the previous four units, differed very little in the animals recovered between the upper and lower levels. The lowest level excavated concluded at a depth of 54 inches.

The low recovery in Unit $\mathrm{E}$ produced the remains of only three domestic food animals and two wild ones: cow, goat, chicken, squirrel, and catfish. Two rodents, one a roof rat (Rattus rattus) and the other not identified, were also found. The squirrel (Sciurus niger) is the only one recovered in Phase I excavations. Levels in Unit $\mathrm{E}$ at 39 inches and in E-1 at 18-24 inches contained the most identifiable genera (three each).

\section{Phase II}

Phase II excavations at the Alamo north wall also produced a large and well-preserved collection of faunal material (Tables A-4, A-5, and A-6). The two units opened, extensions of Phase I units $\mathrm{A}$ and $\mathrm{E}$, yielded 458 bones and bone fragments, of which 97 exhibited butchering marks. Unit EII was established west and north of Unit E from Phase I to further expose features noted in the latter. Likewise, Unit AII was an expansion of A, opened about three feet to the west. The stratigraphy of EII was complex as it crossed several buried structural features. AII was much simpler, resembling $\mathrm{AI}$ in its stratigraphic structure.

\section{Unit AII}

As with Unit A, Unit AII produced the largest count of faunal remains and animals identified; however, the faunal list from AII differs from A. The differences suggest that, despite being stratigraphically similar in composition, they may represent different periods of bone deposition. Identified animals in AII are represented by five types of domestic animals, two kinds of rodents, and eight wild genera. No unit of Phase I produced more wild than domestic animals.

AII resembles all other Phase I and Phase II units in the presence of goats, cows, dogs, chickens, and turkeys. It differs from all Phase I units except $\mathrm{E}$ in lacking identified pig remains. More striking in difference is the presence of two aquatic species other than catfish: alligator and soft-shell turtle. Soft-shell turtles are still abundant in Texas rivers, but the presence of an alligator is today a rarity beyond the coastal bend. Conant (1975:35), however, lists central Texas as within the original range of the reptile. The presence of a river otter (Lutra canadensis) was also unexpected, though its pre-European range was also into central Texas. The only duck and opossum represented in either Phase I or Phase II occurred in AII.

AII closely resembles $A$ in the butcher-marked element category. Vertebrae are the most commonly damaged elements $(n=18)$ followed by ribs $(n=14)$ and long bones $(n=13)$, a distribution similar to the numbers from Phase I, A and B. Butchered pelvic elements are more common in AII than any other unit from either phase. About 19 percent of the bones from AII $(\mathrm{n}=55)$ exhibit butchering marks This percentage is greater than that from any units except EII and C. Considering the disturbed deposits in $\mathrm{C}$, butchered bones in AII exceed all but EII as a percentage of the total level recovery. 
Table A-4. Phase II, Bone Recovery

\begin{tabular}{||l|c|c|c||}
\hline \multicolumn{1}{|c|}{ Provenience } & $\begin{array}{c}\text { Number } \\
\text { Identified }\end{array}$ & $\begin{array}{c}\text { Not } \\
\text { Identified }\end{array}$ & Butchered \\
\hline AII & & & \\
\hline AII - strata 1 & 7 & & 4 \\
\hline AII - strata 2 & 48 & & 17 \\
\hline AII - level 2 & 43 & 23 & 14 \\
\hline $\begin{array}{l}\text { AII - S, strata 3 } \\
\text { (charcoal pocket in south) }\end{array}$ & 62 & 22 & 6 \\
\hline AII - N, strata 3 (outside footing trench) & 57 & 36 & 14 \\
\hline \multicolumn{1}{|c|}{ Total Unit AII } & $\mathbf{2 1 7}$ & $\mathbf{8 1}$ & $\mathbf{5 5}$ \\
\hline EII - army ditch, strata 1 & 5 & 1 & 1 \\
\hline EII - army ditch, strata 2 & 5 & 13 & 7 \\
\hline EII - D2-1/EII-D2-2 acequia fill, strata 1 and 2 & 13 & 11 & 2 \\
\hline EII - D2-2 \\
acequia fill, strata 2 & 17 & 15 & 8 \\
\hline EII - posthole \#3 & & & \\
\hline EII - posthole \#4 & 1 & & 1 \\
\hline EII - wall trench & & 1 & \\
\hline EII & 9 & & 2 \\
\hline EII - strata 2 & 2 & 1 & 1 \\
\hline EII - strata 3-5 & 43 & 11 & 15 \\
\hline EII - strata 6 & 1 & & \\
\hline EII - strata 7 & 5 & 1 & 1 \\
\hline EII - 2053 & 2 & & 1 \\
\hline EII - Lot 24 & 4 & 2 & 2 \\
\hline EII - footing trench, Palisade wall & $\mathbf{1 1 4}$ & $\mathbf{5 6}$ & $\mathbf{4 2}$ \\
\hline Total Unit EII & & & \\
\hline \hline
\end{tabular}


Table A-5. Phase II, Faunal Identification and Occurrence

\begin{tabular}{|c|c|c|c|c|}
\hline Taxonomic Name & Common Name & AII & EII & Domestic \\
\hline \multicolumn{5}{|l|}{ FISH } \\
\hline Ictalurus punctatus & Channel catfish & $\mathrm{x}$ & $x$ & \\
\hline$?$ & Unidentified fish & $\mathrm{x}$ & $\mathrm{x}$ & \\
\hline \multicolumn{5}{|l|}{ REPTILE } \\
\hline Alligator mississippiensis & Alligator & $\mathrm{x}$ & $\mathrm{x}$ & \\
\hline Chrysemys sp. & Painted turtle & & $\mathrm{x}$ & \\
\hline Trionyx spiniferus & Softshell turtle & $\mathrm{x}$ & & \\
\hline Natrix sp. & Water snake & & $\mathrm{x}$ & \\
\hline$?$ & Unidentified snake & & $\mathrm{x}$ & \\
\hline$?$ & Unidentified turtle & $\mathrm{x}$ & $\mathrm{x}$ & \\
\hline \multicolumn{5}{|l|}{$\mathrm{BIRD}$} \\
\hline Gallus gallus & Chicken & $\mathrm{x}$ & & $\mathrm{x}$ \\
\hline Meleagris gallopavo & Turkey & $\mathrm{x}$ & & $\mathrm{x}$ \\
\hline Family Cygninae & Unidentified duck & $\mathrm{x}$ & & \\
\hline$?$ & Unidentified bird & $\mathrm{x}$ & & \\
\hline \multicolumn{5}{|l|}{ MAMMAL } \\
\hline Didelphis virginianus & Opossum & $\mathrm{x}$ & & \\
\hline Lutra canadensis & River otter & $\mathrm{x}$ & & \\
\hline Canis cf. familiaris & Domestic dog & $\mathrm{x}$ & $\mathrm{x}$ & $\mathrm{x}$ \\
\hline Odocoileus virginianus & White-tailed deer & $x$ & & \\
\hline Antilocapra americana & Antelope & $\mathrm{x}$ & $\mathrm{x}$ & \\
\hline Capra hirca & Goat & $\mathrm{x}$ & $\mathrm{x}$ & $\mathrm{x}$ \\
\hline Bos sp. & Cow & $\mathrm{x}$ & $x$ & $\mathrm{x}$ \\
\hline Sigmodon hispidus & Cotton rat & $\mathrm{x}$ & & \\
\hline$?$ & Unidentified rodent & $\mathrm{x}$ & $\mathrm{x}$ & \\
\hline
\end{tabular}


Table A-6. Phase II, Butcher-marked Skeletal Elements by Unit

\begin{tabular}{lrr}
\hline & AII & EII \\
\hline Vertebrae & 18 & 10 \\
Pelvis & 7 & 1 \\
Long bones & 13 & 8 \\
Rib & 14 & 8 \\
Scapula & 1 & 1 \\
Skull and mandible & 0 & 4 \\
Fragments & 2 & 10 \\
\hline \multicolumn{2}{r}{ Totals } & $\mathbf{5 5}$ \\
\hline \hline
\end{tabular}

Generally, large mammals (such as cows) represent the elements most commonly butchered in AII. This differs from Phase I units in which goat and goat-size animal (such as deer) elements were represented in numbers approximately equal to the larger animals.

\section{Unit EII}

Despite being slightly larger than Unit AII, EII produced 36 percent of the Phase II faunal recovery $(n=170)$. Of this, 25 percent $(n=42)$ exhibit butcher marks. Though similar to AII in several respects, EII differs significantly in the absence of birds (including domestic birds) and of several mammals. Some unidentified bird bone fragments were present in the collection, though none assignable to anything more specific than "bird." Every other Phase I and II unit had chicken remains, and all but D and $\mathrm{E}$ of Phase I had turkey remains. Pig and whitetail deer bones are also absent from EII and E.

One major similarity to AII was the presence of an alligator, two turtles, and at least one snake. The painted turtle (Chrysemys sp.) and water snake (Natrix sp.) are both locally abundant today around streams and ponds. That the snake was used as food is conjectural, but entirely possible. Alligators, as mentioned for AII, could have ranged as far as Bexar County in the past. They are a good supply of tasty meat, primarily in their tails, and their hides provide a high quality skin for tanning.

Three domestic species were identified in EII, the fewest number in either phase with the exception of $\mathrm{E}$. Goat, cow, and dog remains were found in the collection. As in AII, wild genera are more numerous than domestic. Including the previously listed reptiles, catfish and antelope remains complete the identified remains from EII. The presence of antelope in the collection is not unexpected, as it once ranged onto the Texas Coastal Plain.

Within EII, several areas of particular interest were excavated. Area EII (2-6 inches) concentrated on an area east of the Army ditch. This area yielded 54 bones and bone fragments, 32 percent of the total recovery in EII. Of this total, 27 percent $(n=15)$ exhibit signs of butchering. Within the unit, butchered cow bones appear to represent a single animal after butchering. Butchered remains of two smaller animals were also found in the unit with turtle and catfish remains. Area EII-D-1/EII-D-2 contained only one antelope bone along with the remains of a soft-shell turtle, a water snake, a catfish, a cow, and an unidentified rodent. The lone alligator occurred in EII, Lot 24. Catfish remains, found in all other Phase I and II units, were found throughout EII. Pectoral spines from these fish match in size to comparative specimens weighing in excess of $10 \mathrm{lbs}$. 
Generally, it can be said that the EII remains closely resemble those of AII in the lack of numerous domesticates and the relative abundance of game animals. Unit EII resembles Unit $E$ in its lack of pig and white-tailed deer remains, and is unique in the collection for its absence of identified domestic birds. Numerous reptiles from EII resemble the large number (as compared to Phase I units) recovered from AII.

\section{Butchering Practices at the Alamo}

A priority of the Alamo North Wall project faunal analysis was to define and detail the butchering process involved in reducing animals to a bone scatter. Identification of the marks was the first step, as about one-fifth of the total collection exhibited some form of butchering marks. These marks provided evidence of the tools used and were defined as the following:

saw cuts-straight, flat cuts often leaving fine striations on the bone, presumably made with a metal hand saw

hack marks-ragged, deep, chop marks defined by $\mathrm{V}$-shaped grooves, made by a meat cleaver or axe

cut marks-thin, short lines from knife use, usually not penetrating the surface of the bone

A fourth mark was also identified, though it indicates a manual manipulation of the bone, often in conjunction with a hack mark or saw cut, rather than a lone tool mark. These were termed green fractures and defined as hinged or "snap-over" fractures at the point where a fresh (green) bone was stressed and broken.

A fifth type of fracture was seen in a single bone from AII (5-3 inches), where an immature humerus of a goat-size animal apparently exhibited a blunt fracture and negative impact scar at the proximal end of the diaphysis. This, and the associated spiral (torsion) fracture, is normally associated with marrow removal in prehistoric butchering practices (Gilbert 1980: 11-14). No other bone in Phase I or II was observed to have been fractured by this method.

To more fully understand the butchering process as exhibited by the Alamo collection, information was sought on rural butchering processes prior to the advent of power saws and centralized slaughter houses. Mr. Howard Collins of Alto, Texas, a master butcher of many years experience, provided valuable answers to many of the questions on rural versus modern butchering and differences in the handling of various animals (personal communication 1983). Much of the following sequence was derived from Mr. Collins.

Butchering strategy, as outlined here, does not necessarily take the meat "all the way to the table." As suggested here, it reduces an animal carcass to basic elements prior to a final cutting for cooking. Problems with spoilage, no doubt, made the trip from hoof to the cooking pot a rapid one. Small cuts of meat familiar to us were probably not practical, as cooking larger portions was more practical, particularly if a number of people were to be fed at once.

To reduce a cow carcass to basic elements utilizing three tools-a knife, a meat cleaver, and a saw-the following steps are generally followed.

1) skin and eviscerate the animal;

2) remove the head with a knife by cutting between the atlas and foramen magnum;

3) remove the lower limbs using the meat cleaver to hack through the tibia or radius above the distal articulation or through the medial portion of the metapodial bones and discard;

4) remove the hind limbs at the pelvis by using a knife to release the femur from 
the acetabulum (socket) in the pelvis, then remove the forelimbs by either using the knife to cut the humerus away from the glenoid fossa of the scapula or using the meat cleaver to hack into the scapula above the articular joint;

5) remove the neck by sawing between the 4th and 5th cervical vertebrae;

6) using the handsaw, split the vertebrae down the middle, dividing the carcass in long halves;

7) quarter the carcass by sawing the long halves through the thoracic region.

At the end of this process the yield is four carcass quarters (two forequarters and two hindquarters), four limbs with meat attached, a neck, and a head. Waste at this point has been confined to the lower limb elements and the carcass has been reduced to a manageable size.

Different animals are handled slightly differently. The lower extremities of smaller animals such as goats or deer do not contain much meat and are likely to be discarded from the proximal tibia down. Pigs, on the other hand contain meat and fatty tissue into their hooves, making this a potential source of meat and less likely to be discarded.

Butchered elements from Phase I and II were compared with the general butchering model presented above. Generally, the animals at 41BX6 were apparently processed in a similar but not identical manner. Vertebrae were the commonly marked bones in every unit except $\mathrm{E}$ and $\mathrm{C}$. This would be expected if the vertebrae had been split with the carcass but this was not the case. Most of the vertebrae had been sawcut diagonally through the centrum or hacked and broken at the dorsal spine (on the thoracic vertebrae) and transverse processes where the ribs articulate.

Ribs were usually the next most numerously marked element followed by long bones. Many of the ribs had been sawed $5-8 \mathrm{~cm}$ below the articular processes whereas others exhibited pronounced cut marks and hack marks near or on the articular processes. Rib fragments were often sawn and cut into small segments without the articular process. Of the identifiable long bone fragments, numerous distal humeri and proximal ulnae and radii were identified in the collection. Likewise, the distal tibia was a commonly identified long bone. Generally, though, these elements belonged to the goats, deer, and antelopes in the Phase I recovery. AII and EII both contain some identified Bos and large mammal long bone fragments whereas only B-3 (33-36 inches) and C-1 (21-27 inches) contain these elements in Phase I.

Scapula and pelvis fragments are fairly common for most butchered mammals, particularly in Units DI and AII. These are almost always hack-marked. The pelvic acetabulum was generally hacked directly into or removed from the rest of the innominate by hacking away the ischium and ilium. Hack marks were also directed towards the area of the scapula about $5-8 \mathrm{~cm}$ above the glenoid fossa. Cut marks, saw marks, and green fractures usually accompanied these hacked areas.

Green fractures were most common in the long bone shafts and were often accompanied by hack and saw marks. Cut and saw marks were most common on vertebrae and ribs whereas hack marks were encountered in every group of elements. Cut marks and saw marks were the rarest on the long bones.

The following modified butchering sequence is suggested from the data.

1) After skinning and eviscerating the animal, the head was generally sawedoff between the axis and atlas (lst and 2nd cervical) vertebrae. Three axis from Phase I and II (representing one goat, one antelope, and one goat-size animal) were sawed suggesting such a removal. However, the only atlas 
recovered (Bos) exhibited anterior cut marks consistent with knife removal, as did one goat axis. Both elements with knife marks were recovered during Phase II.

2) Deer, antelope, and goats had the lower extremities removed by hacking and snapping away the distal tibia of the hind legs, and sectioning-out the humerus/radius/ulna articulation of the forelegs. Cow limbs were generally not treated the same way, as carpals and phalanges were the normal discard. Conversely, pig long bones and lower extremities were a rarity in the collection, suggesting they were, indeed, food items.

3) Fore- and hind-limbs were disarticulated from the carcass by hacking, sawing, cutting, and breaking through the scapula above the glenoid, and into the pelvis through the acetabulum.

4) The neck was removed by sawing, then closely trimmed of remaining meat by sawing and cutting.

5) Instead of splitting the vertebrae longitudinally, the butchers first removed the backstrap meat (paralleling the vertebrae on each side of the backbone) with knives. Once exposed, the large dorsal spines of the thoracic vertebrae were hacked or sawed-off to facilitate straighter cutting. At this point, one of two methods was employed: hacking through the transverse processes, the vertebral column was freed from the ribs and removed; or the carcass was cut into more than quarter sections, sawing directly through the vertebrae. The number of saw-cut and hacked ribs might indicate that the rib sack was removed prior to the final division of the carcass and subdivided into smaller sections.

Missing elements from Phase I and II excavations suggest the major elements were further divided elsewhere, if at all. Skulls and mandibles are notably absent from both collections, as are long bone fragments of cows. Phase I generally produced few unidentified fragments per unit whereas Phase II produced considerable more by comparison. This may be an indirect indicator of further butchering activity past the initial stage of carcass reduction, as crushed and splintered bone is produced by closer cutting and trimming. The more numerous occurrences of large mammal and cow long bone fragments-such as saw-cut femoral articulations in AII Level 2-in the Phase II units suggests some functional difference in the agents responsible for depositing the bone. The distribution of certain skeletal elements in certain units, such as five scapulae and four pelves in Unit D and four skull and mandible elements in EII, certainly suggests some grouping of elements for efficiency of butchering or division of butchering labor. The scarcity of burned bones (a total of 17 for both phases) argues that no major cooking effort was being undertaken in any of the units.

Based solely on skeletal age, immature animals were butchered less often than mature animals. While it is doubtful the Alamo inhabitants could afford the luxury of slaughtering young domestic animals for tender meat, none of the animals examined had matured to any great extent. A single fetal animal and a very young goat were identified in Phase II collections, and immature chickens appeared in several units, however. Skeletal age is somewhat deceiving, though, as a cow may not mature skeletally until 5-7 years but may easily reproduce before then. 


\section{Subsistence at the Alamo}

Phases I and II of the Alamo North Wall project revealed a subsistence regimen based on domestic animals supplemented by wild fish and game. Collections such as this usually contain non-food animals as well, though predicting what people do and do not consider food is problematical. Animals such as the wood rat, cotton rat, and roof rat could have entered the remains as natural scavengers or disposed carcasses, just as the cat. In the case of the cat, it is likely the lone tooth was a scavenging loss. Likewise, the water snake from Phase II could have been a disposal, a meal, or even a natural inhabitant of the trash heap.

Among the domestic animals, dogs are frequent but mostly identified from isolated teeth. Scavenging losses are probable, but dog may have served as table fare. Cow, goat, and pig remains were no doubt the product of butchering. The single horse bone and horse tooth identified were not necessarily the product of butchering. Value as a pack animal often makes horses too valuable to slaughter, though by no means exempts them from the human diet. Once again, how this animal entered the collection is unknown, but butchering residue is a possibility.

All the wild animals identified in the collection were locally available to the inhabitants of the Alamo. Although over a dozen are represented, only the catfish, white-tailed deer, and antelope occur with any frequency. Of those three, the catfish is ubiquitous in the collection while the antelope is only represented by a single individual in Phase I and two individuals in Phase II.

Of particular interest between the Phase I and II excavation collections is the occurrence of several aquatic or aquatically bound species in Phase II. In addition to the alligator, a painted turtle, a soft-shell turtle, a water snake, a duck, and a river otter were identified. These aquatic or water-dependent animals did not occur in
Phase I collections. Of the 16 identified species excavated in Phase II, seven (counting the catfish) had to have been taken from riverine or marshy areas. Wild species in Phase I units numbered nine, with one (the channel catfish) coming from an aquatic environment.

That all Phase I units have domestic animals outnumbering wild animals and that both Phase II units have wild animals outnumbering domestics suggests differences in the depositional history of each.

1) The collections are contemporary and represent different butchering episodes and hunting forays into different environments.

2) The collections represent two different episodes (at least) during different time periods. The Phase II assemblage might represent earlier Alamo subsistence in the absence of well established domestic herds, particularly of pigs, chickens, and turkeys. Phase I collections might represent a later Alamo more dependent on established domestic stock and more opportunistic and selective in terms of wild species exploited. 


\section{References Cited}

Conant, $\mathrm{R}$.

1975 A Field Guide to Reptiles and Amphibians of Eastern and Central North America. Houghton Mifflin, Boston.

Gilbert, B. M.

1980 Mammalian Osteology. Modern, Laramie, Wyoming. 


\title{
Appendix B: Osteobiography of the Alamo North Wall Cranium
}

\author{
David M. Glassman and D. Gentry Steele
}

\section{Introduction}

This report describes the morphology of the cranium excavated at the Alamo site, 41BX6, during the 1979 North Wall field season. The fragmentary cranium is the sole human skeletal material recovered from the site during this excavation.

\section{Skeletal Description}

The recovered fragments of the 41BX6 cranium are pieced and glued to approximate normal articulation. The cranium is missing the entire region of the face inferior to the frontal border, except for portions of the left and right nasal bones. The neurocranium (comprised of the frontal, parietal, occipital, and temporal bones) is present although a few areas are fragmentary, particularly on the base of the skull and in the pterion (spheno-frontal) areas. The zygomatic arches are fragmentary and consist solely of portions of the zygomatic process of the temporal bones for both the left and right sides. Portions of the sphenoid bone are present on the cranial base and sides of the neurocranium. The left and right mastoid processes are present, as are portions of both auditory canals. Neither the mandible nor any of the dentition is present.

The preservation of the cranium is very good. A minor degree of distortion is present and is attributable to external pressure compressing the skull while it was buried. This pressure appears to have caused some cracking of the cranial surface, particularly in the region of the sagittal suture where a series of cracks is found to radiate laterally. Burial pressure may also be responsible for the complex network of surface cracking on the frontal bone. There is little or no indication of animal activity on the bones and little alteration from the infiltration of vegetation. The color of the cranial bones is a light brown to tan, indicating little or no exposure to the sun during the interment period.

\section{Morphological Observations}

The overall appearance of the cranium is small and gracile. The metopic (medio-frontal) suture is retained on the frontal bone. This suture, which separates the two infant frontal bones, generally becomes fused and obliterated within the first two years after birth. The retention of this suture into adolescence or adulthood is rare, occurring in less than 10 percent of the individuals in most populations. The neurocranial sutures remain unfused ectocranially (the outer surface of the cranium). It appears that initial endocranial fusion of the neurocranial sutures had begun, although this is difficult to determine given the present condition of the cranial remains. The spheno-occipital synchondrosis (basilar suture) appears to have been unfused.

General morphological characteristics of the cranium include a slight appearance of the supraorbital ridges, a blunt superior border of the eye orbit, small to moderately sized mastoid processes with a small supra-mastoid crest on the left side only, a small to moderately sized foramen magnum with small to moderately sized occipital condyles, and a small degree of frontal bossing. Cranial musculature indicated by the development of the areas of muscle attachment (principally the attachment areas of the temporal and nuchal muscles) is not pronounced. 


\section{Metric Observations}

The fragmentary and incomplete nature of the 41BX6 cranium restricts the number of accurate metric observations which may be taken for descriptive purposes. Obtainable measurements and indices are provided in Table B-1. Measurement values followed by an asterisk indicate the value is estimated.

The metric observations of the 41BX6 cranium are descriptive of an average individual. The cranial index indicates this individual as being orthocranic, or having an average head height. The breadth-height index and the fronto-parietal index suggest the head shape may be slightly higher and broader than average. Overall, the skull shape is characterized by its lack of distinctive morphology.

\section{Age at Death}

Age at death of the individual represented by the $41 \mathrm{BX} 6$ cranium is estimated from the degree of closure of the neurocranial sutures. These sutures appear to have begun initial fusion endocranially, yet remained distinct on the exterior surface of the skull. Subsequently, it is noted the fragmentation pattern of the skull occurred primarily along the suture lines. This pattern would not have been expected if the neurocranial sutures had been completely fused prior to death.

The degree of suture closure indicates an estimated age of 17 to 23 years. This age estimate is supported by the morphology of the spheno-occipital synchondrosis which suggests having not been completely fused by the time of

Table B-1. Metric Observations of the 41BX6 Cranium

\begin{tabular}{|l|r|}
\hline \multicolumn{1}{|c|}{ Measurement } & \multicolumn{1}{c|}{ Value } \\
\hline 1. Maximum cranial length & $180 \mathrm{~mm}$ \\
\hline 2. Maximum cranial breadth & $135 \mathrm{~mm}$ \\
\hline 3. Basion-bregma height & $* 133 \mathrm{~mm}$ \\
\hline 4. Mastoid length (left) & $20 \mathrm{~mm}$ \\
\hline 5. Mastoid length (right) & $* 19 \mathrm{~mm}$ \\
\hline 6. Minimum frontal breadth & $97 \mathrm{~mm}$ \\
\hline 7. Foramen magnum length & $* 30 \mathrm{~mm}$ \\
\hline 8. Foramen magnum breadth & $25 \mathrm{~mm}$ \\
\hline 9. Nasion-basion length & $* 99 \mathrm{~mm}$ \\
\hline Cranial index $([2 / 1] \times 100)$ & 75.0 \\
\hline Cranial module $([1+2+3] / 3)$ & 149.3 \\
\hline Length-height index $([3 / 1] \times 100)$ & 73.9 \\
\hline Breadth-height index $([3 / 2] \times 100)$ & 98.5 \\
\hline Fronto-parietal index $([6 / 2] \times 100)$ & 71.9 \\
\hline
\end{tabular}

*estimated 
death. This synchondrosis closes and is obliterated by approximately 23 years of age in most individuals. The lack of other skeletal material which is more diagnostic of age makes this assessment tentative.

\section{Gender}

Gender determination of the $41 \mathrm{BX} 6$ cranium is difficult due to a mosaic pattern of genderrelated morphological traits. The overall appearance of the cranium suggests a young adult male. However, individual characteristics such as the absence of pronounced supraorbital ridges, mastoid processes, and development of the areas of muscle attachment suggest a more female appearance. The presence of the frontal eminences is also more typical of females than males. The young age of the individual might, to some extent, explain the lack of muscular development. In addition, gracility may be a genetic condition more common in some populations, such as Mexican Americans. It is best to suggest the cranium probably belonged to a younger male with the possibility of female not being totally ruled out.

\section{Biological Affinity}

Determination of the biological affinity of the 41BX6 cranium is of interest given its historical importance. Morphological differentiation is therefore sought between Hispanic, non-Hispanic Anglo, and Native American patterning. Unfortunately, few traits which can be used for this ethnic differentiation exist, particularly in the 41BX6 cranium which is lacking the entire facial region. Furthermore, it is possible that tri-populational (Hispanic, Anglo, and indigenous Native Americans) interbreeding occurred among the populations which existed in this region. This intermixing of genes from different groups would result in diminishing definitive biological affinity characteristics.
Nevertheless, the sagittal and lambdoidal sutures are both simple, a feature not typical of Native Americans and more typical of individuals of European derived ancestry. Similarly, the gracile nature of the cranium is more typical of European ancestry (and more so of Mexicans) than Native American.

These few features suggest that the cranium most likely did not belong to a Native American. Whether the 41BX6 cranium represented a Hispanic, a non-Hispanic Anglo, a mestizo or other population can not be determined with confidence.

\section{Cause of Death}

Numerous cracks, holes, and depressions on the 41BX6 cranium deserve consideration in assessing the cause of death. The missing face itself may be indicative of some antemortem trauma or a time interval between death and burial in which the skeleton was subjected to a myriad of taphonomic forces resulting in modification of the bone. Certainly disarticulation occurred as well as desiccation. Most of the surface cracks can be attributed to ground pressure sustained by interment and therefore not indicative of the manner of death. The largest holes (missing areas, exclusive of the facial elements) in the cranium are located in the left and right pterion regions, the left parietal near lambda, the region of the right mastoid, posterior to the foramen magnum, and surrounding the basilar portion of the occipital bone. The holes range to approximately $2 \mathrm{~cm}$ in diameter. Whether the holes were formed ante- or postmortem is unknown.

A final feature of interest is a modification to the left frontal. Here, a depression or gash, measuring $2.6 \mathrm{~cm}$ long and $0.2 \mathrm{~cm}$ wide at its widest point, runs obliquely over the left eye The depth of the defect is generally shallow, but in the center reaches the diploe layer. The gross pattern of this defect is consistent with sharp trauma. However, under microscopic 
examination of the area, neither crushing in the region nor smooth cut edges appear, both of which would have been suggestive of a sharp blow occurring to the region while the bone was fresh. This leads to a conclusion that the defect may or may not reflect antemortem trauma.

No other features found on the 41BX6 cranium were considered possibly associated with the cause of death.

\section{Summary}

Given the limited data available, it is our opinion that the most plausible osteobiography of the 41BX6 cranium is of a young adult male between 17 and 23 years of age and of unknown ethnicity. Glassman suggests there is indication the individual may have been subjected to antemortem trauma of the head including a possible knife or saber wound above the left eye; Steele, however, feels the damage to the frontal above the eye represents postmortem damage. The incompleteness of the remains suggests a time interval between death and burial or the cranium had been secondarily deposited from some other primary site. Regardless of the mode of deposition, the cranium was subjected to numerous taphonomic changes. 